UNIVERSIDADE DE SÃO PAULO

FACULDADE DE FILOSOFIA, LETRAS E CIÊNCIAS HUMANAS PROGRAMA DE PÓS-GRADUAÇÃO EM GEOGRAFIA HUMANA

KLEBER WILSON VALADARES FELIZARDO DA SILVA

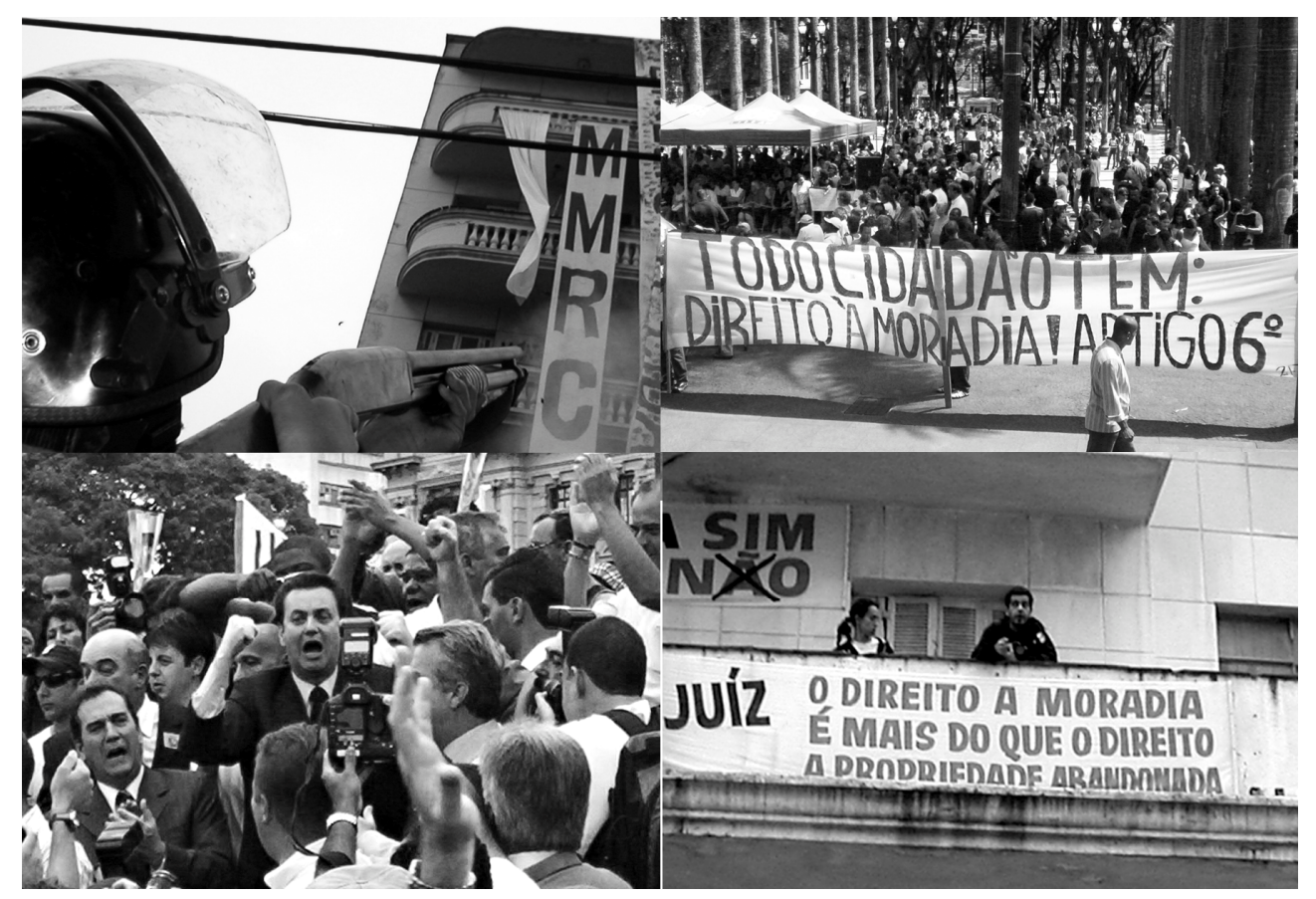

O problema da habitação no contexto da revalorização do Centro Histórico de São Paulo (1991-2006)

São Paulo 2007 
KLEBER WILSON VALADARES FELIZARDO DA SILVA

\section{O problema da habitação no contexto da \\ revalorização do Centro Histórico de São Paulo}

(1991-2006)

Dissertação apresentada ao Programa de Pós-Graduação em Geografia Humana da Universidade de São Paulo para obtenção do título de Mestre em Geografia.

Orientadora: Profa. Dra. Glória da Anunciação Alves 


\section{RESUMO}

O objetivo desta dissertação é analisar o uso e a apropriação do espaço na cidade de São Paulo na perspectiva do processo de revalorização do seu Centro Histórico. A análise focaliza, sobretudo, os problemas relacionados aos planos e estratégias voltados para o reforço da função habitacional desta região. Dentre as estratégias do poder público para a revalorização do Centro estão incluídas propostas que estimulam o seu uso habitacional. Entretanto, em torno deste objetivo se evidenciam diferentes interesses dos agentes sociais (dentre os quais estão a Associação Viva o Centro e o Fórum Centro Vivo) que entram em conflito pelo uso e apropriação deste espaço. Neste cenário de disputas em torno do Centro Histórico de São Paulo, averiguam-se, ainda, como as diretrizes e instrumentos contidos no Estatuto da Cidade sobre o uso do solo são aplicados nesta centralidade e quais seus possíveis efeitos.

\section{Palavras-chave:}

São Paulo, Revalorização de Centro Histórico, Habitação, Conflitos Sociais, Estatuto da Cidade.

\section{Abstract}

This dissertation aims at analyzing the usage and appropriation of space in the city of São Paulo from the perspective of the Historic Center's revaluation process. The focus of the analyses lies mainly on problems related to the plans and strategies directed to reinforce the region's residential function. Proposals to stimulate its residential function are included among the policy strategies to revalue the Historic Center. However, different interests of social agents (Associação Viva o Centro and Fórum Centro Vivo among others) around this objective become evident. These social agents start a conflict over the usage and appropriation of the space. In this setting, the application and possible effects of the guidelines and instruments contained in the City's Statute on the usage of soil in this locality are further investigated.

\section{KEY WORDS:}

São Paulo, Historic Center's Revaluation, Housing, Social Conflicts, City’s Statute. 
para Marilene, pelo amor e dedicação incondicionais 


\section{AgRADECIMENTOS}

É chegado o momento de agradecer às incontáveis pessoas que contribuíram para que esse Mestrado se concretizasse.

Primeiramente, agradeço à Fapesp pelo suporte financeiro sem o qual a realização deste trabalho, realmente, não seria possível.

As professoras Odette Carvalho de Lima Seabra e Arlete Moysés Rodrigues contribuíram de modo extremamente significativo para essa pesquisa, por meio de seus instigantes comentários no Exame de Qualificação.

A minha orientadora Glória da Anunciação Alves esteve sempre pacientemente disponível aos meus inúmeros questionamentos e dúvidas. Essa sua solicitude para com os orientandos é realmente louvável.

Aos inúmeros amigos devo a companhia ao longo dessa jornada que foi o Mestrado.

Os companheiros do Grupo de Estudos Adailton, Aglaé, Ana, Ângela, Emerson, Michel, Nanci, Nedir, Neide, Sandro e Wilson fizeram da atividade acadêmica um exercício um pouco menos solitário e enriquecedor.

Há também os amigos que colaboraram diretamente para a confecção deste trabalho. Ao Guilherme e à Isadora, pela enorme força na última hora. A querida Isabel pode não ter abraçado São Paulo, mas com toda a certeza já abraçou os amigos paulistanos. Ela se tornou aqui, a tradutora oficial de todos os Abstracts da turma.

As amigas do tempo de Unesp, Branca e Sandra, tornaram-se parceiras aqui na USP. À Sandra agradeço os bons conselhos e a ajuda providencial. À querida Branca nem sei como retribuir as boas gargalhadas e momentos de descontração.

Ainda dos amigos de Rio Claro cabe lembrar da Simone, Carnaval, Lívia, Will, BH, Fabi, Regina e Tati, que são amigos, ainda hoje, para todas as horas.

À Leane, Paula e Aluani tenho de agradecer pela sempre carinhosa acolhida na casa que já adquiriu status de meu segundo lar. A semana em que estive com vocês foi fundamental para a conclusão dessa pesquisa.

Vaninha e Joana também participaram ativamente desta Dissertação, principalmente nos momentos em que podíamos e queríamos falar, nas saudosas saideiras, sobre qualquer outra coisa que não estivesse relacionada a este universo. 
Maurício, Christiane, Nanci, Mariana, Gabão e Roger são os amigos herdados e queridos, aos quais sempre foi possível recorrer. Quem sabe agora consigamos remarcar tudo o que precisou ser adiado em função da Dissertação?

Ao Zé e à Érica, pessoas que fazem lembrar o quanto é importante ter amigos, ou melhor, bons amigos por perto. À Peçanha já nem sei o quanto devo. Tomara que um dia eu possa retribuir à altura a sua amizade.

À medida que se aproxima o fim desses agradecimentos, as coisas vão ficando mais complicadas... Como seria possível agradecer à família? Resta-me apenas tentar!

Aos tios e primas agradeço pela torcida e incentivo. À vó Nica, agradeço o carinho, apesar da minha ausência nos últimos dois anos.

A vida de mestrado se tornou muito mais prazerosa quando encontrei alguém para amar. Rafa, você sabe o quanto a sua presença faz diferença...

Às minhas queridas irmãs, Marie e Keyla, não há agradecimento suficiente que possa retribuir o amor e a torcida incondicional.

Aos meus pais, Enio e Marilene, agradeço por estarem sempre por perto garantindo carinho, força, incentivo, alegria... 


\section{LISTA DE ILUSTRAÇÕES}

Figura 1 - Município de São Paulo: delimitação da região central

Figura 2 - Centro Histórico (Distritos República e Sé)

Figura 3 - Novos prédios no Centro de São Paulo

Figura 4 - Folheto com propaganda do projeto de reurbanização do Vale do Anhangabaú

Figura 5 - Área Especial de Interesse da Operação Urbana Centro

Figura 6 - Zeis Aprovadas no PDE, em estudo na SEHAB e sugeridas 105 pelos moradores e movimentos de moradia da subprefeitura Sé

Figura 7 - "Cracolândia". Operação Limpa 


\section{LISTA DE TABELAS}

Tabela 1 - População residente e crescimento populacional do 43 Município de São Paulo e dos seus distritos - 1991-2000

Tabela 2 - Localização dos conjuntos populares e unidades 45 concluídas até 1997, segundo órgãos promotores e localização

Tabela 3 - Domicílios particulares vagos nos distritos centrais de São Paulo - 2000

Tabela 4 - Número de moradores de rua do Município de São 47 Paulo, segundo distritos - 2000

Tabela 5 - Distribuição dos domicílios, por faixas de renda 48 familiar, segundo distritos do Município de São Paulo - 2000 


\section{SUMÁRIO}

$\begin{array}{ll}\text { Introdução } & 1\end{array}$

1. Contextos do processo de revalorização do Centro Histórico de São Paulo 15

1.1 Revalorização do centro histórico: traçando o contexto - identificando 15 os discursos

1.2 Revalorização do Centro Histórico: retomando algumas premissas 34

1.3 Dinâmicas recentes do Centro Histórico de São Paulo 42

1.4 Revalorização do Centro Histórico de São Paulo: gentrificação em curso? 53

2. Associação Viva o Centro x Fórum Centro Vivo : conflitos pelo uso e 57 apropriação do espaço no Centro de São Paulo

2.1 A Associação Viva o Centro e o processo de revalorização no Centro 57 Histórico de São Paulo

2.1.1 O posicionamento da Associação Viva o Centro em relação à habitação 65 na região central

2.2 O Fórum Centro Vivo e o processo de revalorização do Centro Histórico 68 de São Paulo

3. O poder público e o processo de revalorização do Centro Histórico de São 82 Paulo: o problema da habitação

3.1 Gestão Luiza Erundina - Partido dos Trabalhadores (1989-1992) 82

3.2 Gestão Paulo Maluf - Partido Progressista (1993-1996) 89

3.3 Gestão Celso Pitta - Partido Progressista (1997-2000) 93

3.4 Gestão Marta Suplicy - Partido dos Trabalhadores (2001-2004) 99

3.5 Gestão José Serra/ Gilberto Kassab - Partido da Social Democracia 107 Brasileira/ Democratas (2005-2008)

3.6 Delineando semelhanças e diferenças entre as gestões municipais 114

4. O Estatuto e a cidade: incidências e efeitos da Lei $n^{0} \mathbf{1 0 . 2 5 7}$ sobre o uso do 117 espaço no Centro de São Paulo

4.1 Estatuto da Cidade: processos anteriores à sanção da Lei n ${ }^{\circ} 10.257 \quad 118$

4.2 Delineamento geral sobre o conteúdo do Estatuto da Cidade 124

4.3 A questão do centro à luz do Estatuto da Cidade e do Plano Diretor 131

de São Paulo

4.4 O estado atual das coisas: o Estatuto permanece como possibilidades

135

Considerações finais

Bibliografia

Fotos da capa: Isadora Lins/cmi-sp 


\section{@ INTRODUÇÃo}

\section{Volta ao Centro em 450 anos...}

A pouco mais de um ano de comemorar seu $450^{\circ}$ aniversário, São Paulo prepara sua terceira fundação, ao estabelecer a rota de volta ao centro. Formada por um crescente cinturão cultural, ela significa uma alteração inédita na história da cidade, cujo crescimento sempre ocorreu das regiões centrais para a periferia.

Aquele centro, imaginado no século 19 como um aprazível recanto europeu, submergiu as drogas, ambulantes, desempregados, meninos de rua. Prédios foram abandonados. A decadência afastou muito de seus freqüentadores para as novas zonas nobres que, rapidamente, também deixavam de ser nobres, numa autofagia urbana.

A terceira fundação ensaia agora os seus primeiros passos. Depois de décadas se expandindo geométrica e caoticamente para a periferia, imersa numa crise de identidade de quem se destrói e não sabe se construir, a cidade inicia um movimento inverso. Ensaia um encontro com sua história e olha para si mesma, como se, depois de quatro séculos e meio, apalpasse a identidade que, mal se formou na multiplicidade de culturas, sotaques, dialetos, logo foi perdida.

Sintomaticamente, a cúpula do poder municipal retorna para junto do primeiro local que recebeu os jesuítas - e que ainda permanece cercado de enchentes.

Os problemas são muitos: embora as estatísticas favoreçam, o centro não é uma ilha de segurança. As multidões de ambulantes e mendicantes também são desafios a ser superados. Faltam garagens para os paulistanos, que são viciados em automóveis.

Mas são muitos os fatores que impulsionam essa força centrípeta: prefeitura, governos estadual e federal, comerciantes, empresas nacionais e estrangeiras, ONGs, associações de moradores.

O conjunto de teatros, cinemas, centros culturais e museus na região delineia um cinturão cultural no centro - a maior concentração de arte e cultura por metro quadrado.

Grandes hotéis são inaugurados após 20 anos sem lançamentos do setor na região. E a fibra óptica que corre no subsolo atrai empresas de tecnologia.

Junto com essas mudanças, gente chegando, atraindo as mais diversas tribos. São arquitetos, artistas plásticos, atores, agitadores culturais: procuram imóveis de muito espaço e pouco preço, charme, história. Procuram a sensação de que numa metrópole tão dispersa e desfigurada, americanizada e africanizada, o centro é um ponto de equilíbrio (FOLHA DE S. PAULO, 2002, p.1).

O texto acima reproduzido faz parte de uma série de artigos e matérias que compõem o caderno Folha Trainee publicado no ano de 2002 pela Folha de São Paulo ${ }^{11}$ - um dos jornais de maior circulação no país. Inspirado na proximidade dos festejos

\footnotetext{
${ }^{11}$ Trata-se de um caderno especial publicado anualmente pelo jornal, e que é resultado da pesquisa de jovens jornalistas que aspiram uma vaga de trabalho neste veículo de comunicação. Em geral, para escolha do tema a ser abordado no Folha Trainne se leva em consideração questões que sejam atuais e de interesse do público leitor.
} 
para a celebração dos 450 anos de fundação da capital paulista, este caderno traz como tema principal “A volta ao Centro de São Paulo". Segundo os editores, a importância de abordar esta questão reside no fato de que ela expressa um momento sem equivalentes para a história da cidade: a sua " $3^{\mathrm{a}}$ fundação", ou seja, "uma alteração inédita na história da cidade de São Paulo, cujo crescimento sempre ocorreu das regiões centrais para a periferia" (FOLHA DE S. PAULO, 2002, p. 1).

Em suma, a proposta deste caderno é retratar as recentes transformações realizadas no Centro Histórico de São Paulo, que têm implicado em mudanças de caráter paisagístico, funcional e de uso deste espaço. Embora não haja nos dias de hoje um elemento sequer que possibilite aferir a respeito da estagnação da expansão periférica de São Paulo, os editores tomam as recentes transformações ocorridas no Centro, como elementos para especular a respeito de uma alteração na dinâmica de crescimento desta cidade, que agora supostamente se realizaria na direção periferiacentro.

Ainda que este caderno seja pontuado por uma série de equívocos ${ }^{12}$, optou-se por tomar um dos seus trechos para iniciar a introdução desta dissertação, pois as idéias ali veiculadas apontam para o tema central desta pesquisa, ou seja, a revalorização do Centro Histórico de São Paulo, ao mesmo tempo em que reproduzem o discurso geralmente pronunciado pelos agentes que comandam este processo: o Estado e a iniciativa privada, sendo este último agente representado, na maior parte das vezes, pela Associação Viva o Centro (AVC).

O processo que será analisado nesta dissertação e que é denominado por revalorização ${ }^{13}$ do Centro Histórico de São Paulo consiste, em linhas gerais, em um conjunto de intervenções físicas e normativas realizadas no Centro da cidade, a partir de estratégias traçadas pelo poder público municipal, nas quais estão impressos, também, os interesses dos setores privados. Tais intervenções buscam propiciar a transformação do uso e das funções deste espaço como forma de torná-lo competitivo

\footnotetext{
${ }^{12}$ Neste caso, é preciso questionar se o que está apresentado no jornal é somente equívoco ou se existe uma finalidade que determina esta imprecisão.

${ }^{13}$ Nesta Dissertação foi feita a opção pelo emprego do termo revalorização para se referir às recentes transformações impostas ao Centro Histórico de São Paulo, tendo em vista a prevalência, neste processo, de uma estratégia que pretende estabelecer um novo valor para o espaço como elemento para valorização do próprio capital. Cabe acrescentar que diferentes termos, como revitalização, reconstrução, resgate, reabilitação, requalificação, renovação e etc., foram empregados para se referir a este mesmo processo pelos agentes a ele relacionado, tais como: poder público municipal, Associação Viva o Centro e Fórum Centro Vivo. Embora esta pesquisa reconheça as especificidades e finalidades distintas do uso de cada um desses termos, considerou-se revalorização o mais adequado para analisar o processo aqui estudado.
} 
ou novamente atraente aos investimentos de caráter privado, bem como, propiciar uma nova valorização aos bens aí já investidos.

Pode-se recolher do trecho citado uma série de elementos do discurso ideológico que permeia as atuais estratégias de revalorização do Centro da cidade, dentre eles: o resgate de uma história que está esquecida; a valorização do patrimônio cultural e histórico; o investimento em melhorias infra-estruturais, para permitir novos usos do espaço (turismo, serviços, empresas de tecnologia) e atrair novos usuários (artistas, universitários, agitadores culturais). Vista desta maneira, a "volta ao centro ensaiada pela cidade de São Paulo" aparenta ser um processo pleno em positividades e isento de contradições.

O discurso que se reproduz, não permite entrever a maior parte dos interesses que determinam e induzem a revalorização do Centro Histórico de São Paulo, como é o caso do empenho do mercado imobiliário, ávido por novas possibilidades de lucro com as transformações realizadas no espaço urbano. Tudo se resolve como se a cidade, “imersa em uma crise de identidade", ensaiasse o seu despertar. Deste modo, a cidade é considerada como sujeito de um processo que, por sua vez, é concebido como se fosse natural e imune de intencionalidades.

Deve-se salientar que este "movimento de retorno" ao Centro Histórico de São Paulo procura se efetivar mediante a superação da deterioração desse mesmo espaço, a qual é expressão do seu esvaziamento econômico e populacional (com especificidade para as classes de maior rendimento) iniciado nos anos 60. Como resultado deste esvaziamento, até os dias de hoje é possível encontrar imóveis abandonados no Centro da cidade, cuja tendência foi, ao longo do tempo, de declínio do seu valor e das condições físicas ou estruturais, bem como de habitalidade. Do mesmo modo, deve-se reconhecer que muitas dessas áreas deixadas permanentemente (e estrategicamente) sem uso estão à espera de uma nova valorização, que pode advir inclusive como fruto de novos investimentos do setor público. Tal medida se tornará um negócio extramente lucrativo para os proprietários imobiliários da região.

Caminhando ao encontro da retórica do Estado e dos agentes privados, na presente citação se difunde, também, um discurso classista que procura associar a deterioração do Centro ao seu uso pela população pobre ou de menor poder aquisitivo: ambulantes, desempregados, meninos de rua que constituem, conforme enunciado, o "desafio a ser superado". Dentro da mesma ótica, celebra-se a chegada dos novos usuários ou moradores: "arquitetos, artistas plásticos, atores, agitadores culturais..." que 
“... procuram imóveis de muito espaço e pouco preço, charme e história”. Ou seja, uma população com outro perfil cultural e econômico, capaz de cumprir o plano que para elas está traçado, isto é, o consumo dos novos espaços revalorizados. Neste caso, é possível questionar se por trás da sentença "gente chegando, atraindo as mais diversas tribos" está oculta uma tendência de gentrificação ${ }^{14}$ do espaço urbano, no contexto do processo de revalorização do Centro Histórico de São Paulo?

É para o novo usuário e consumidor do Centro Histórico que se adotam políticas de animação cultural voltadas para a construção de museus, teatros e centros de lazer. Ao mesmo tempo, estes equipamentos passam a ser utilizados na promoção do próprio espaço urbano, como âncoras para a sua valorização imobiliária, assim como, para a produção de uma representação sobre este espaço que permita desconstruir uma imagem que o concebe como decadente, violento, desvalorizado. A partir disso, pretende-se sugerir que o Centro agora está qualificado e reúne atributos culturais como nenhum outro lugar da cidade.

Embora conflituoso, todo este processo é representado por meio da constituição de um cenário harmonioso, camuflando os embates que se estabelecem pela apropriação do espaço urbano. Se de um lado o poder público e os agentes da iniciativa privada se associam para levar adiante este processo de revalorização do Centro da cidade, por outro lado, os movimentos sociais se colocam contrários a estas medidas, e passam a reivindicar o direito à habitação, trabalho e lazer no Centro da cidade. Contudo, se torna necessário avançar em termos de análise para iluminar estes conflitos e desvendar as contradições, muitas vezes, encobertas por um discurso que tende à homogeneização deste processo.

As estratégias para revalorização do Centro Histórico de São Paulo seguem uma tendência mundial e procuram alçar a região central à condição de "território fecundo da cidade", ou seja, o lugar da cidade que concentra as vantagens locacionais para um novo período de dinamismo sócio-econômico da metrópole paulistana e para a sua inserção na rede de cidades mundiais. Este discurso é, em grande parte, produzido e difundido pela Associação Viva o Centro, que desde 1991 mantém um papel atuante frente às transformações em curso no Centro de São Paulo. Pode-se afirmar que esta associação é o principal agente ideológico de todo este processo, tendo em vista que

\footnotetext{
14 A gentrificação diz respeito ao processo de deslocamento dos moradores das classes populares do centro das cidades, pela atração de setores das classes médias e altas (SMITH, 2006).
} 
suas idéias e interesses são, na maior parte das vezes, prontamente encampados pelo Estado $^{15}$.

A realização de intervenções urbanísticas e normativas, somadas à consolidação da imagem do Centro como "território fecundo" da cidade delineia, em parte, as estratégias dos agentes promotores da revalorização do Centro no afã de propiciar o retorno das sedes de empresas e a atração de setores do comércio, lazer, turismo, assim como, a produção de novas habitações na região central como estímulo à atração de novos moradores. Pretende-se que a multifuncionalidade do Centro Histórico - ou seja, a concentração das mais distintas funções e atividades neste espaço - seja a marca característica da sua revalorização. Estende-se que esta chamada multifuncionalidade possa ser o diferencial da região central na corrida por novos investimentos frente à competição com as demais centralidades existentes em São Paulo.

No que diz respeito à questão da habitação no Centro Histórico da cidade, cabe ressaltar que arquitetos e urbanistas reconhecem que o afastamento gradual de numerosas parcelas dos moradores agravou a situação de abandono e desvalorização do Centro. Portanto, reforçar a sua função habitacional constituiria um dos principais elementos indutores da sua requalificação. Deste modo, promover a moradia na região central passa a ser uma das ações estratégicas dos agentes que comandam a revalorização deste espaço.

Como será analisado, ao projeto de revalorização do Centro Histórico de São Paulo são incorporadas propostas visando o estímulo à habitação nesta região, mas cabe questionar os resultados concretos e o alcance/extensão social de tais propostas. Tal questionamento ganha evidência a partir da análise da atuação dos movimentos sociais que resistem à revalorização da região central e que, na contramão do que pronunciam os agentes hegemônicos, passam a denunciar este processo como gerador de desigualdade e segregação sócio-espacial. De modo enfático, estes movimentos apontam que as intervenções urbanísticas realizadas no Centro da cidade têm promovido a expulsão das classes populares ou de menor baixa renda que já o habitavam.

\footnotetext{
15 Deve-se considerar que apesar da Associação Viva o Centro ter sido fundada oficialmente no ano de 1991, parte daqueles agentes que ela passou a representar já participavam, mesmo antes da sua fundação, dos debates que envolviam a intervenção do Estado no Centro Histórico de São Paulo, ou seja, mesmo que não organizados em torno de uma associação estes agentes já declaravam ao poder público os seus interesses para esta região da cidade.
} 
Além da denúncia que fazem, os movimentos sociais passam a reivindicar o direito à moradia no Centro de São Paulo, tendo em vista o déficit habitacional existente na cidade e o número elevado de imóveis mantidos sem uso na região central. Entretanto, tal reivindicação tende a conflitar com os demais interesses que concebem o reforço da função habitacional do Centro como elemento estratégico para a sua revalorização, pela tendência ao aporte de novos investimentos do setor privado na reforma e construção de edifícios, que possibilitaria um maior dinamismo imobiliário na região, bem como, a atração de uma população com maior renda e poder aquisitivo.

Pode-se pensar, portanto, que pelo habitar da região central se torna possível entrever os conflitos pelo uso e apropriação do espaço no Centro Histórico de São Paulo, que colocam em lados opostos os sujeitos que lutam pelo direito à moradia na região central - como elemento para a reprodução da vida -, e os agentes que avistam no reforço da função habitacional do centro um elemento estratégico para a valorização imobiliária da região - como elemento para a reprodução do capital imobiliário, bem como dos demais setores econômicos.

A hipótese dessa pesquisa é a de que, no intuito de promover a revalorização do Centro Histórico de São Paulo, as estratégias comandadas pelo Estado, aliado aos interesses da iniciativa privada, ao se concretizarem, não se dão sem prejuízos à forma como as classes populares habitam este espaço. Conforme será analisado, grande parte das políticas públicas até aqui definidas e implementadas com vistas à promoção de um adensamento populacional do Centro Histórico de São Paulo, bem como, os conflitos resultantes das práticas levadas a cabo pelo Estado e pela iniciativa privada parecem indicar que a atual estratégia de revalorização desse espaço caminha no sentido de construir outro processo de segregação sócio-espacial nessa área, restringindo o seu uso e a sua apropriação a determinados segmentos da sociedade.

A possibilidade de constituição de um processo segregacionista no Centro Histórico de São Paulo a princípio feriria as diretrizes que regem o Estatuto da Cidade - Lei Federal nº10.257/01 que fixa parâmetros para a aplicação da política urbana presente na Constituição de 1988, definindo as condições de cumprimento da função social da propriedade e da cidade -, pois as normas que nele estão previstas, assim como os instrumentos de intervenção urbanística nele contidos, sinalizam para uma crítica à inclusão perversa da população de menor rendimento, ou empobrecida, no processo de (re)produção das cidades brasileiras. 
Com efeito, tal como outras estratégias presentes no espaço urbano, as propostas de revalorização do Centro Histórico da cidade de São Paulo, no que tange ao uso da propriedade urbana, estão submetidas às normas do Estatuto da Cidade. Faz-se indispensável, no entanto, investigar de que forma estas normas para política urbana incidem sobre a questão das áreas centrais e o problema da habitação no Centro da cidade. Neste caso, cabe perguntar: teria esta política urbana uma real potencialidade de reverter o processo de segregação sócio-espacial que se expressa em São Paulo?

O objetivo que está proposto nesta dissertação é o de analisar o uso e a apropriação do espaço na cidade de São Paulo na perspectiva do processo de revalorização do seu Centro Histórico, com foco, sobretudo, nos impactos gerados sobre o problema da habitação. De um modo mais específico, pretende-se analisar as ações comandadas pela Prefeitura Municipal ${ }^{16}$ e pela iniciativa privada - representada pela Associação Viva o Centro (AVC) - que visam reforçar a função moradia no Centro; o conflito estabelecido entre esses agentes e os movimentos sociais que lutam pela apropriação deste espaço - neste caso, considerando a atuação do Fórum Centro Vivo (FCV) -, bem como, diante das diretrizes e instrumentos urbanísticos contidos no Estatuto da Cidade averiguar as incidências e possíveis efeitos da operacionalização desta política urbana sobre a ordenação e uso do solo no Centro da cidade de São Paulo.

Estas análises incorporarão os acontecimentos que compreendem o período entre os anos de 1991 e 2006. Esta delimitação se justifica porque é a partir do ano de 1991 que foi possível constatar uma maior ênfase à revalorização do Centro Histórico de São Paulo, com a constituição da Associação Viva o Centro e a definição, por parte do poder público (gestão Luiza Erundina - 1989 a 1992), de um conjunto de intervenções urbanísticas visando superar o processo de deterioração deste espaço ${ }^{17}$. Tais intervenções tiveram continuidade ao longo das sucessivas gestões que

\footnotetext{
${ }^{16}$ Embora, tanto o Governo do Estado de São Paulo, como a União, em menor escala, participem e interfiram no processo de revalorização do Centro Histórico de São Paulo, optou-se metodologicamente por analisar somente as ações comandadas pelo poder público municipal.

17 Deve-se ressaltar que desde os anos de 1970, tal como aponta Kara José (2004), já eram postas em práticas estratégias que visavam a recuperação do Centro de São Paulo, dentre elas, as obras de restauração do Edifício Martinelli (que hoje é sede da Secretaria de Habitação do Município de São Paulo), a construção dos calçadões, as obras do metrô, a recuperação do Viaduto do Chá e do Pátio de Colégio, que compunham o "Plano de Revitalização do Centro" elaborado na gestão Olavo Setúbal (1975-1979). Este plano tinha como referência os projetos internacionais de revitalização urbana que surgiram no mundo em meados da década de 1960. No presente estudo, busca-se enfatizar os acontecimentos que se iniciam a partir da década de 1990, quando às ações do poder público somam-se, efetivamente, as estratégias da iniciativa privada para a revalorização do Centro Histórico de São Paulo.
} 
administraram a cidade - respectivamente, Paulo Maluf (1993-1996); Celso Pitta (19972000); Marta Suplicy (2001-2004), e José Serra/Gilberto Kassab (gestão que teve início em 2005$)^{18}$ - e as propostas elaboradas por cada uma dessas administrações públicas são objeto de análise desta pesquisa. Cabe ressaltar que o ano de 2001 pode representar um marco neste processo de revalorização do Centro devido à regulamentação do Estatuto da Cidade e o seu aporte como um possível elemento para redefinir as práticas, até então, concretizadas.

Nesta pesquisa está delimitada como área de estudo os Distritos República e Sé, pertencentes à Subprefeitura Sé $^{19}$ do município de São Paulo, uma vez que esta área se constitui como um espaço de interesse e de atuação do Estado e da iniciativa privada no que tange à implementação de estratégias para a revalorização do Centro Histórico e para reforçá-lo como um espaço de moradia da cidade.

Tendo claro alguns pontos que direcionam a pesquisa realizada, a presente dissertação está estruturada da seguinte maneira:

Capítulo 1 - Neste primeiro capítulo, dentre outros aspectos, foram apresentados os pressupostos teóricos nos quais estão embasadas as análises desta pesquisa. Para isso, são retomadas algumas formulações teóricas de Henri Lefebvre, especificamente no que tange a uma interpretação do processo de produção do espaço na sociedade capitalista, e de autores que já se dedicaram à análise dos processos de transformação espacial do Centro Histórico de São Paulo e que oferecem relevantes aportes para a presente pesquisa.

Delimitados os pressupostos teóricos, buscou-se traçar a contextualização da revalorização do Centro Histórico de São Paulo, deste modo, tecer uma análise temporal, procurando demarcar o momento em que o Estado, aliado aos interesses da iniciativa privada, inicia um amplo processo de transformação da região central. Estabelecido este ponto de partida, procurou-se identificar as premissas e, também, os discursos ideológicos que permeiam este processo até o período recente, bem como, analisar os efeitos das intervenções urbanísticas e normativas no Centro da cidade sobre a apropriação e o uso desse espaço. Neste caso, considerando as estratégias levadas a

\footnotetext{
${ }^{18}$ No ano de 2005, José Serra (PSDB) se candidatou e foi eleito Governador do Estado de São Paulo, e em seu lugar tomou posse na Prefeitura de São Paulo Gilberto Kassab (DEM), que, até então, era o Viceprefeito do município.

${ }^{19}$ A Subprefeitura Sé compreende, além distritos República e Sé (o chamado Centro Histórico), os distritos Bela Vista, Bom Retiro, Cambuci, Consolação, Liberdade e Santa Cecília e representa a região central do município de São Paulo, conforme Lei Municipal nº13.399/02.
} 
cabo pelo poder público municipal e os interesses manifestados pelos agentes privados representados pela Associação Viva o Centro.

Em contraposição às estratégias e práticas do poder público e aos interesses da Associação Viva o Centro foi delineada uma análise que evidencia as premissas dos movimentos sociais - tendo como referência a atuação do Fórum Centro Vivo -, que em geral reivindicam o direito à habitação do Centro de São Paulo pelas classes populares, e se opõem à sua revalorização evidenciando, portanto, a eminência de um processo que não se realiza sem manifestar a sua face conflituosa.

Neste primeiro capítulo buscou-se, também, localizar e discutir o problema da habitação no âmbito do processo de revalorização do Centro Histórico de São Paulo, buscando compreender as distintas concepções envoltas em uma estratégia do poder público que procura reforçar a região central como espaço de moradia da cidade, porém, ora afinada com as demandas das classes populares, ora voltada aos interesses do setor imobiliário e à atração para o Centro das classes de maior renda e poder aquisitivo, como forma de estabelecer uma mudança no perfil sócio-econômico da população desta região.

Ainda neste capítulo são levantados e analisados dados quantitativos que possibilitam entrever o atual quadro social do Centro Histórico de São Paulo e fazer considerações a respeito da sua dinâmica imobiliário recente. Por fim, é esboçada uma discussão a respeito da verificação de um processo de gentrificação a partir do processo de revalorização da região central.

Capítulo 2 - Neste segundo capítulo, mediante a análise dos discursos e identificação das demandas colocadas de um lado pela Associação Viva o Centro, e de outro pelo Fórum Centro Vivo, foi possível estabelecer uma maior compreensão em relação aos conflitos pelo uso e apropriação do espaço no Centro Histórico de São Paulo. Este conflito passa a ter evidência a partir dos interesses manifestados por cada um desses agentes: enquanto a Associação Viva o Centro defende - embora não explicite - os interesses particulares dos agentes que vislumbram novas possibilidades de reprodução do capital no Centro da cidade e a valorização do patrimônio imobiliário existente; os movimentos e entidades sociais, articulados em torno do Fórum Centro Vivo, buscam uma apropriação do espaço pela afirmação do seu valor de uso e para a reprodução da vida.

$\mathrm{Na}$ construção das análises realizadas neste capítulo foram empregadas distintas metodologias de pesquisa. Para a investigação sobre a atuação da Associação Viva o 
Centro no processo de revalorização do Centro Histórico de São Paulo, seu discurso e a sua interlocução com o poder público municipal, tomou-se como referência as publicações produzidas e veiculadas por esta instituição. Neste caso, tanto as publicações elaboradas pela sua equipe técnica, como as publicações comerciais a partir das quais divulga à sociedade o seu discurso ideológico, a exemplo da revista "URBS - Viva o Centro".

Já a análise sobre as reivindicações pronunciadas pelo Fórum Centro Vivo baseou-se, primordialmente, nas informações colhidas por meio da pesquisa de campo. Esta pesquisa foi realizada entre os meses de outubro de 2006 e fevereiro de 2007, e consistiu no acompanhamento das reuniões e dos atos públicos realizados pelo $\mathrm{FCV}^{20}$. Por outro lado, as publicações produzidas pelo próprio Fórum também serviram de referência para a análise realizada. Dentre estas publicações, pode-se mencionar o "Dossiê de denúncia - violações dos direitos humanos no centro de São Paulo".

Capítulo 3 - Neste terceiro capítulo, busca-se investigar os discursos, as estratégias e as práticas efetivadas pelo poder público municipal no que concerne ao processo de revalorização do Centro Histórico de São Paulo e às propostas para o reforço da função habitacional deste espaço.

Nesta análise foram examinados os documentos elaborados nas diferentes gestões municipais que administraram São Paulo ao longo do período de 1991 a 2006 (tendo como referência o recorte temporal desta pesquisa). Pôde-se utilizar, também, as informações coletadas nas atividades de acompanhamento de encontros e seminários que contaram com a participação de representantes da prefeitura do município, e que colocaram em pauta as recentes intervenções e transformações na região central de São Paulo.

A partir do objetivo traçado, foi possível analisar de modo específico como em cada uma das gestões municipais está colocada a questão da habitação no contexto da revalorização do Centro Histórico São Paulo, e assim, identificar as premissas que

\footnotetext{
${ }^{20}$ Durante este período foi possível participar de um total de 9 eventos. O acompanhamento das atividades do FCV surgiu como sugestão das professoras Arlete Moysés Rodrigues e Odette Carvalho de Lima Seabra, que avaliaram os primeiros encaminhamentos desta pesquisa no exame de qualificação. A banca examinadora constatou que as discussões realizadas sobre a habitação e o processo de revalorização do Centro Histórico de São Paulo estavam centradas no discurso do poder público e da Associação Viva o Centro em detrimento de uma análise que considerasse as premissas dos movimentos sociais. Por considerar que esta proposta traria importantes aportes à pesquisa, optou-se por acatar a sugestão realizada.
} 
orientaram as estratégias de intervenção no espaço urbano, bem como, os diferentes interesses que foram sendo contemplados ou valorizados ao longo do tempo. Ao final deste capítulo, foi empreendido um esforço na tentativa de traçar possíveis simetrias e distinções entre as idéias formuladas e as práticas efetivadas pelas distintas gestões municipais.

Capítulo 4 - Tendo como referência a recente promulgação do Estatuto da Cidade, portanto, a sanção presidencial às normas legais que prescrevem a função social da cidade e da propriedade urbana para os municípios brasileiros, busca-se compreender como as diretrizes e instrumentos desta política urbana incidem sobre o uso do solo no Centro da cidade e quais os possíveis efeitos já constatados a partir da sua operacionalização.

A análise realizada recuperou alguns dos processos que antecederam a promulgação do Estatuto da Cidade, como forma de explicitar os conflitos existentes e o aporte dos movimentos populares à sua aprovação. Na sequiência, foi estabelecido um delineamento do conteúdo desta lei, identificando as diretrizes e os instrumentos urbanísticos que, formalmente, passam a incidir sobre o uso do solo em parte das cidades brasileiras.

Neste quarto capítulo foi realizada, também, uma análise da abordagem do Estatuto da Cidade e do Plano Diretor de São Paulo - identificando os discursos tanto do governo federal, quanto do poder público municipal - sobre os problemas relacionados ao uso e ocupação do solo nas chamadas áreas centrais e históricas da cidade. Por fim, buscou-se avaliar alguns dos resultados que podem ser delimitados como conseqüência da possível efetividade do Estatuto da Cidade (das suas diretrizes e instrumentos contemplados pelo Plano Diretor municipal) no Centro Histórico de São Paulo.

Tendo cumprido todo o percurso para análise do problema da habitação no contexto da revalorização do Centro Histórico de São Paulo, como forma de desfecho desta dissertação são encaminhadas algumas considerações finais. 
os Capítulo 1 
Figura 1: Município de São Paulo: delimitação da região central.

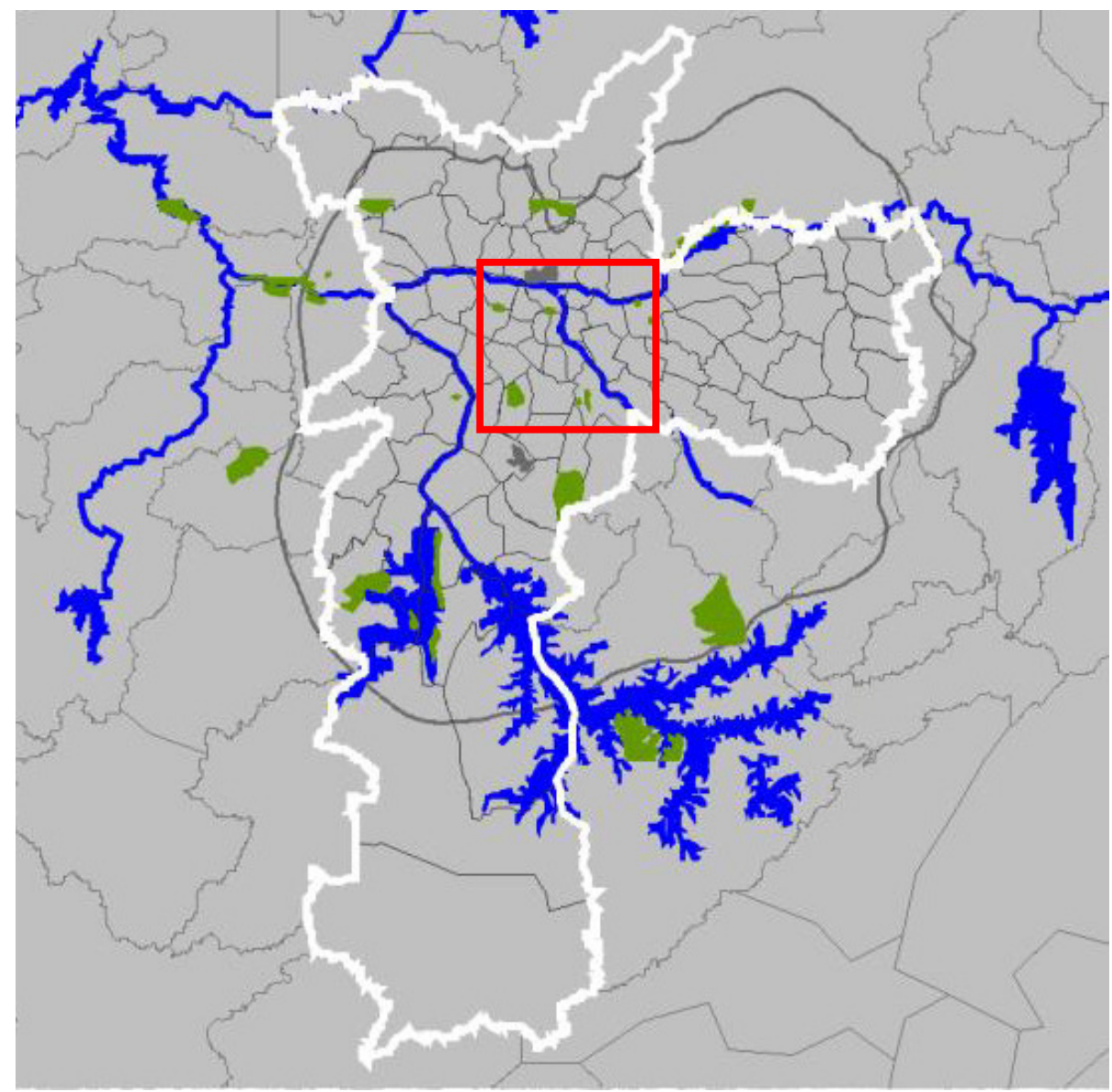

Fonte: (SÃO PAULO, 2004) 
FIGURA 2: Centro Histórico (Distritos República e Sé)

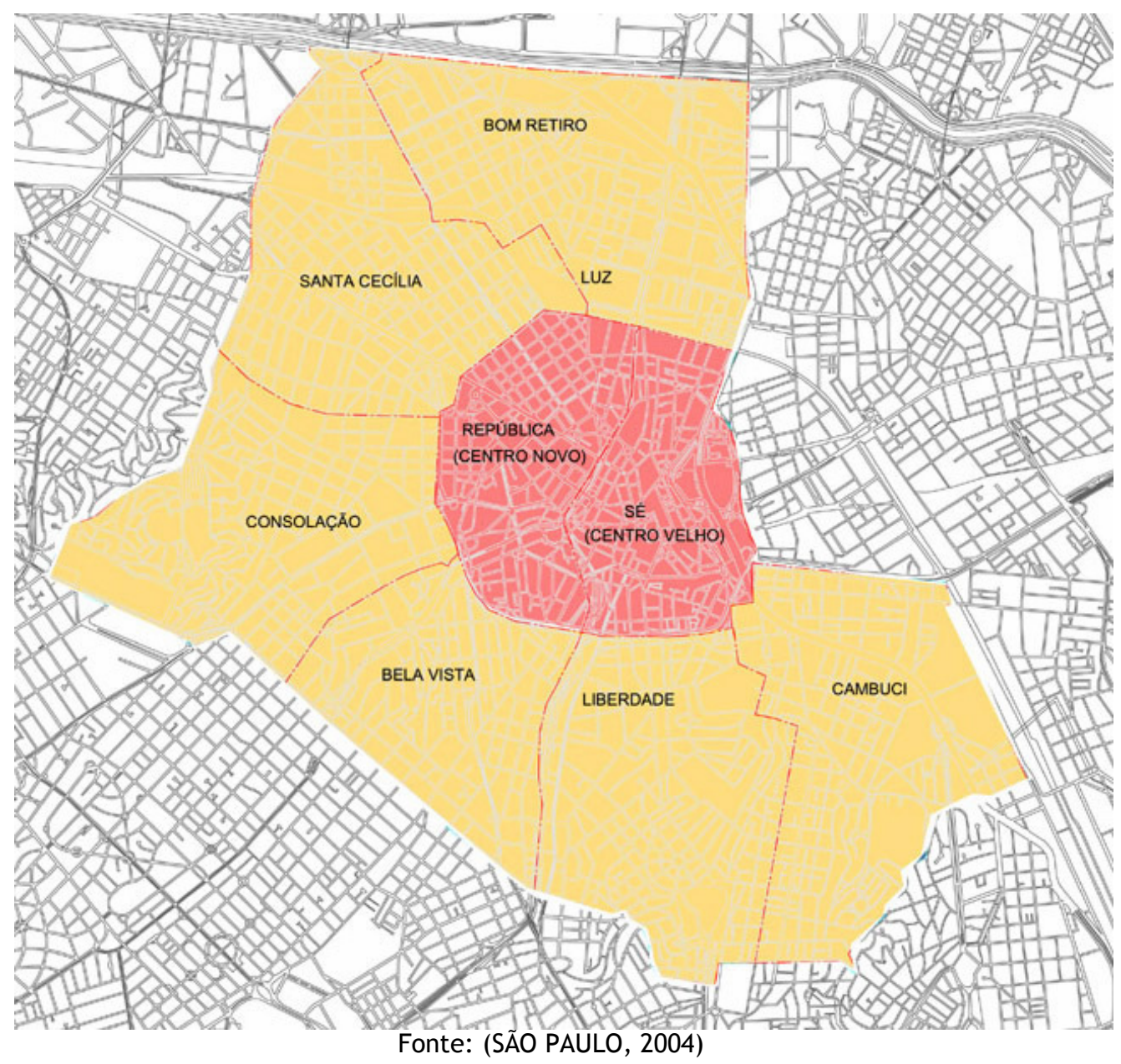


ơ 1. CONTEXTOS dO PROCESSO DE REVALORIZAÇÃo do Centro Histórico de SÃo Paulo

\subsection{Revalorização do Centro Histórico de São Paulo: traçando o contexto - identificando os discursos}

A revalorização do Centro Histórico de São Paulo se enquadra na perspectiva da reprodução do capital a partir dos interesses de determinados setores econômicos, dentre eles, o setor imobiliário, o setor de serviços, turismo, etc. Deste modo, a "volta ao centro" traz o significado do retorno ${ }^{21}$ desses agentes a espaços onde a reprodutibilidade do capital ainda é possível. É nesse sentido que são delimitadas estratégias para transformação do Centro Histórico e do uso deste espaço, visando, com isso, torná-lo mais adequado aos interesses desses agentes econômicos.

No presente período histórico, partindo-se da conformação de uma sociedade capitalista, o espaço urbano aparece regulado pelas leis do mercado, tornando-se bem material ou mercadoria consumida de acordo com as leis da reprodução do capital. Concebido a partir da estratégia capitalista, o espaço é sobrepujado em sua dimensão de lugar de atuação homem, de realização da vida cotidiana e de meio para a atividade produtiva, passando a ser produto deste mesmo processo produtivo. Ou seja, o espaço é concebido como objeto de troca para o consumo de uma parcela da população que dispõe de recursos econômicos e financeiros. Segundo Lefebvre:

O desenvolvimento do mundo da mercadoria alcança o continente dos objetos. Esse mundo não se limita mais aos conteúdos, aos objetos no espaço. Ultimamente o próprio espaço é comprado e vendido. Não se trata mais da terra, do solo, mas do espaço social como tal, produzido como tal, ou seja, com esse objetivo, com essa finalidade [...]. O espaço não é mais simplesmente o meio indiferente, a soma dos lugares onde a mais valia se forma [...] Ele se torna produto do trabalho social, isto é, objeto muito geral da produção, e, por conseguinte, da formação da mais valia (LEFEBVRE, 1999, p. 142, grifo do autor).

À medida que avança em direção à realização da reprodução do capital, pela generalização da mercadoria e do valor de troca, o espaço tende a se tornar limitado enquanto meio de reprodução da vida, restringindo a possibilidade de realização das interações sociais, bem como, da sua apropriação pela sociedade. É nesse sentido que se

\footnotetext{
${ }^{21}$ Se é que algum dia efetivamente o deixaram.
} 
pode afirmar que na cidade capitalista "o valor de troca prevalece a tal ponto sobre o uso e o valor de uso que quase suprime este último" (LEFEBVRE, 2001, p.13).

Dentro deste contexto se insere o atual processo de revalorização do Centro Histórico de São Paulo, o que sugere que o espaço tende a ser valorizado em menor grau pela sua possibilidade de uso pelo conjunto da sociedade ou dos cidadãos, mas, sobretudo, pela possibilidade de reproduzir o capital, isto é, por tornar eficientes os processos de produção, circulação e consumo de mercadorias, bem como, de formação da mais valia.

Deve-se reconhecer, porém, que este processo não se apresenta como uma via de mão única, pois a população que habita o Centro ou que o tem como lugar de referência na sua vida cotidiana - seja para o trabalho, o lazer e o consumo; seja para o encontro com os demais cidadãos nas festas populares que ainda lá se realizam; seja, também, porque este é o lugar que ocupa e onde deseja viver (a exemplo dos movimentos sociais dos sem-teto do Centro de São Paulo) - revela, pela sua apropriação do espaço, que o valor de uso ainda resiste mesmo que, com o decorrer do tempo, venha sendo suplantado pelo valor de troca. Segundo Lefebvre:

Os núcleos urbanos [...] resistem ao se transformarem. Continuam a ser centros de intensa vida urbana. As qualidades estéticas desses antigos núcleos desempenham um grande papel na sua manutenção. Não contém apenas monumentos, sede de instituições, mas também espaços apropriados para as festas, para os desfiles, passeios, diversões. O núcleo urbano torna-se, assim, produto de consumo de uma alta qualidade para estrangeiros, turistas, pessoas oriundas da periferia. Sobrevive graças a este duplo papel: lugar de consumo e consumo do lugar. Assim, os antigos centros entram no modo mais completo na troca e no valor de troca, não, sem continuar a ser valor de uso em razão dos espaços oferecidos para atividades específicas (LEFEBVRE, 2001, p. 12).

Tal argumento permite entrever que o espaço urbano, com especificidade para os Centros tradicionais, embora seja produzido para o consumo das classes de maior renda, ainda retém a sua dimensão de espaço de uso e a sua possibilidade de apropriação pela parcela restante da sociedade. Sendo assim, contempla o valor de troca sem por isso inviabilizar o valor de uso. Esta relação é resultado dos diferentes interesses que sobre este espaço convergem: de um lado, o Estado e os grupos que detêm o capital agem na defesa de seus anseios - a dominação do espaço para a reprodução capitalista - de outro, habitantes do Centro resistem e lutam pelo uso do espaço e pela sua perspectiva de apropriação (ALVES, 1999). 
O processo de revalorização do Centro Histórico de São Paulo pode ser remetido aos idos dos anos 90. Foi a partir deste período que o Estado passou, de modo mais intenso, a realizar intervenções físicas e normativas no espaço urbano, tendo como finalidade promover a valorização dos bens presentes no Centro, e torná-lo novamente atraente aos investimentos de caráter privado. Nesta perspectiva, a revalorização pode ser compreendida como um conjunto de políticas públicas e de estratégias de intervenção urbana voltadas à transformação do espaço e do seu uso, tornando possíveis a sua reordenação e a sua refuncionalização, em busca de uma valorização patrimonial da região e de dinamizá-la economicamente.

Nesta medida, é importante ressaltar que, além de propiciar investimentos para atrair e tornar rentáveis novos negócios na região central da cidade, as estratégias para a revalorização do Centro Histórico de São Paulo buscam, também, garantir aos agentes capitalistas a manutenção do patrimônio ou renda já investido nesse espaço, bem como, adotar medidas para superação do seu processo de deterioração e, com isso, evitar uma onda de desvalorização imobiliária e o declínio dos demais investimentos lá realizados (ALVES, 2004, 2005).

Entretanto, é necessário enfatizar que este "movimento de retorno" do poder público ao Centro de São Paulo se anunciara em períodos anteriores à década de 90. Deste modo, já nos anos $70^{22}$, mais especificamente na administração do prefeito Olavo Setúbal (1975 - 1979), foram efetivadas algumas estratégias visando, basicamente, a recuperação patrimonial da região central da cidade, o que era manifestado como uma política de revitalização do Centro - este era o termo recorrentemente utilizado à época - que estava entendida como “... qualificação e valorização ambiental, com manutenção e recuperação do patrimônio edificado" (KARA JOSÉ, 2004, p. 10).

A pauta que estava colocada naquele momento era a da superação da deterioração do Centro da cidade. Esta deterioração era compreendida como resultado da desvalorização imobiliária e da degradação do patrimônio histórico da região central, motivadas pelos problemas relacionados ao congestionamento, à poluição atmosférica e sonora, que contribuíram para afugentar a população de renda alta e média para outras áreas da cidade (SILVA, H., 2000). O que ocorreu na esteira dos novos investimentos do mercado imobiliário que passara a verticalizar a porção sudoeste de São Paulo.

\footnotetext{
${ }^{22}$ O que ainda não exclui momentos anteriores à década de 70. Segundo Simões Jr. (1994), já nas primeiras décadas do século XX foram realizadas intervenções para "renovação" do centro da cidade.
} 
As estratégias para recuperação patrimonial da região central lançadas nos anos 70 contemplaram, especificamente, a modificação da estrutura viária para a implantação de vias de circulação exclusiva de pedestres (calçadões), a restauração de edifícios históricos - como o Edifício Martinelli ${ }^{23}$-, e a reforma e ou remodelação das praças (Praça da Sé, Praça da República e Largo São Bento) que passaram a abrigar as primeiras estações do metrô no Centro de São Paulo ${ }^{24}$ (SIMÕES JR., 1994). Essa política de revitalização do Centro tinha como finalidade "atrair para a área central os interesses que haviam migrado para outras regiões da cidade" (KARA JOSÉ, 2004, p. 29), bem como, impor limites a um movimento de ocupação popular que começou a ser delineado neste lugar a partir dos anos $60^{25}$.

Pode-se afirmar que algumas dessas finalidades que motivaram o poder público à realização de intervenções urbanas no Centro da cidade (no período anterior aos anos 90) são reafirmadas nos anos recentes, contudo, no âmbito de uma estratégia mais ampla, e que vai além das operações de caráter pontual - revitalização de edifícios históricos, ruas e praças - ao prescrever uma vasta transformação (do uso) deste espaço, pela sua revalorização imobiliária e como condição para a reprodução dos agentes econômicos da cidade. São essas considerações que permitem compreender haver um processo de revalorização do Centro Histórico de São Paulo, que não mais, ou somente, se realiza pela ótica reforma/restauração do patrimônio histórico manifestadas nas políticas de revitalização.

Portanto, a partir dos 90 uma série de políticas públicas passou ser delimitada, pelo poder público, colocando o Centro da cidade como uma das áreas prioritárias para a sua intervenção. Um dos elementos diferenciais que se evidencia nesse período, é a notória participação dos agentes privados na definição de premissas para transformação espacial da região central. Esta articulação público-privada se revelará como um dos elementos fundamentais para a compreensão do processo de revalorização do Centro Histórico.

\footnotetext{
${ }^{23}$ Segundo Kara José (2004), o edifício Martinelli abrigou até os anos 50 escritórios e demais atividades que serviam à elite paulistana. Entretanto, ao ser desocupado por esta população, teve início (década de 60) o seu processo de encortiçamento pelas classes de menor poder aquisitivo. Todavia, a presença dos populares no Martinelli - que era tida como degradante - teve fim quando o poder público tomou o edifício e deu início à sua reforma.

${ }^{24}$ Frúgoli Jr. (2000) observa que associada à reforma da Praça da Sé havia a intenção do poder público de alterar o seu uso deste lugar, tendo em vista que ele era um espaço da cidade que estava ocupado pelas classes populares.

${ }^{25}$ Esta questão será retomada com maior detalhamento no decorrer deste trabalho.
} 
A revalorização do Centro Histórico de São Paulo passa a fazer sentido pelo reconhecimento de que o Centro constitui uma área em processo de deterioração e desvalorização. São muitos os elementos que se associam para determinar a ocorrência desses processos, dentre eles, pode-se destacar o esvaziamento econômico e populacional (das classes de maior poder de consumo) da região central - que deixou em desuso, e com escassa manutenção, porções deste espaço -, como resultado de uma estratégia política e econômica baseada na produção de novas centralidades para o trabalho, consumo e lazer na cidade de São Paulo.

A deterioração do Centro Histórico passa a ser um entrave ao pleno desenvolvimento desta região, portanto, a superação desta condição é o que move a sua revalorização - assim quer fazer acreditar o discurso do poder público. Entretanto, a ocorrência deste processo ao mesmo tempo em que pode representar um entrave, pode ser encarada como um elemento facilitador das novas estratégias de intervenção sobre o espaço urbano. Isto porque, pautado na degradação do Centro e pela necessidade de superá-la, o poder público constrói um discurso de fácil assimilação pela sociedade, como forma de justificar o porquê de novos investimentos nesta região, e não em áreas com problemas prementes, a exemplo da periferia de São Paulo. Ao mesmo tempo, a gradativa desvalorização do Centro Histórico, como decorrência deste mesmo processo de deterioração, permite aos agentes econômicos vislumbrar novas possibilidades de ganhos ou lucros pela atribuição de um novo valor ao patrimônio imobiliário lá existente.

Ainda assim, é necessário compreender que há, efetivamente, um processo de deterioração do Centro que, conforme já apontado, pode estar associado, sobretudo, à falta de manutenção e de novos investimentos e, até mesmo, pela própria ação do tempo que faz ruir a mais rígida das estruturas. Entretanto, a sua ocorrência ao mesmo tempo em que passa a legitimar a intervenção do Estado, parece propiciar o momento aguardado pelo circuito imobiliário para fazer desse espaço a sua nova frente de investimentos.

A partir das premissas desenvolvidas por Simões Jr. (1994) é possível considerar que a revalorização do Centro Histórico representa "o instante em que o mercado imobiliário - que numa fase anterior havia preterido o centro por outros locais onde a reprodução de seu capital pudesse ocorrer de forma mais intensa - passa a realizar a operação-retorno” (SIMÕES JR., 1994, p. 12, grifos do autor). Deste modo, constitui como um processo, entre os momentos de "decadência" e o (provável) "apogeu" da 
região, em que o espaço é readequado e renovado, em termos de estrutura, para atender, entre outros, aos requisitos do mercado imobiliário. Entretanto, como será visto, não é dessa maneira que este problema é apresentado para toda a sociedade.

Além da superação da deterioração da região, o poder público procura afirmar que é, também, pelo reencontro com o dinamismo político, econômico e social outrora apresentado pelo Centro Histórico de São Paulo que se estabelecem as estratégias para a revalorização deste espaço. Porém, é necessário compreender que as forças que se associam para tornar possível este objetivo não procuram simplesmente resgatar, para o presente, um espaço de importância histórica da cidade. Não se trata, desse modo, de um projeto baseado em nostalgias ou em saudosismos. Pelo contrário, é pela transformação do espaço - do seu uso - e pelas novas possibilidades - de troca - que ele irá permitir, que são traçadas estratégias visando a sua revalorização. Os interesses que se afirmam na reprodução desse espaço concebem a sua história apenas como instrumento para a realização estratégica do presente.

Retomando a história do Centro Histórico de São Paulo, é possível observar que no século XIX e durante boa parte do século XX, esta região cumpria o papel de centralidade única da cidade. Portanto, constituía o lugar de concentração do poder político e econômico, bem como, o espaço de referência para toda sociedade paulistana, pois, já era sede dos órgãos públicos municipais e da própria prefeitura do município; era também o lugar de convergência da massa de trabalhadores das indústrias, que estavam aglomeradas no Centro e no seu entorno; do mesmo modo, constituía o destino preferencial de grande parte da população, em busca de serviços, lazer e do consumo.

O Centro também se configurava como um espaço público por excelência, pois não encerrava a possibilidade de convívio e de encontro entre pessoas que compunham partes distintas de uma sociedade, cujas divisões em classes já estavam bem delimitadas. Embora a região central predominasse como lugar de moradia, consumo e negócios para uma população abastada, a população de baixa renda também encontrava neste espaço os meios para realizar as suas necessidades cotidianas.

Nas estratégias para revalorização do Centro Histórico, o Estado, bem como, os agentes da iniciativa privada, buscam enaltecer este caráter pretensamente democrático da região central. Ou ainda, se servem deste fator para justificar o movimento de retomada desta região. Todavia, o discurso por eles elaborado comumente se desdobra em torno da promoção de uma diversidade social na região central da cidade. Ou seja, a retomada do Centro contemplaria a convivência entre as classes populares (que já se 
fazem presentes na região), com os setores da classe média e quiçá as camadas de alta renda. Portanto, revalorizar o Centro seria a maneira de retomar o elo de convivência entre as distintas classes sociais. Como alerta D'Arc, o argumento utilizado considera que “... é na diversidade social que esta volta se justificaria: o centro é também o único lugar onde ela teria alguma chance de realizar-se" (D'ARC, 2006, p. 278). Entretanto, como afirma Silva H., "não se conhece nenhuma política de revitalização do centro que não tenha sido acompanhada de valorização e da conseqüente expulsão das famílias mais pobres..." (SILVA, H., 2000, p. 2). Sendo assim, é necessário analisar os planos elaborados e as práticas efetivadas por estes agentes para compreender se por trás deste discurso da diversidade social não está camuflada uma prática, cada vez mais efetiva, de gentrificação do espaço urbano e o acirramento de um processo de segregação sócioespacial.

No processo de revalorização do Centro Histórico, o chamado "patrimônio histórico, arquitetônico e cultural" (edificado no Centro da cidade) passa a ser um dos chamarizes, senão o principal, para tais estratégias de intervenção urbana. Neste sentido, grandes recursos são investidos para tornar factível a recuperação de edifícios históricos e a sua posterior refuncionalização em espaços de cultura, como os novos centros culturais, museus, teatros ou salas de espetáculos. O projeto em voga tenta mostrar a revalorização do Centro se dá, entre outros, por meio do reencontro com a memória e a história da cidade. Entretanto, tal projeto não deixa claro que, muito além do sentido simbólico que tanto a história quanto a memória possam ter para a sociedade que as acumulou e produziu, a estratégia em questão tende a associar estes elementos ao conjunto de fatores econômicos capazes de atrair para o Centro os novos usuários ou consumidores do espaço. Como afirma Arantes: "se trata de uma apropriação do espaço legitimada pelo upgrading cultural" (ARANTES et alii, 2000, p. 31).

Como exemplo para essas considerações, pode-se fazer referência à implantação no Centro Histórico de São Paulo de novos equipamentos culturais, como: o Centro Cultural Banco do Brasil (inaugurado em 2001), o Conjunto Cultural da Caixa Econômica Federal (inaugurado em 2004), o Centro Cultural dos Correios (em fase de implantação), o Masp Centro (inaugurado em 2000 na galeria Prestes Maia ${ }^{26}$ ), etc. Ou

\footnotetext{
${ }^{26}$ O projeto de ocupação da galeria Prestes Maia pelo Masp (Museu de Arte de São Paulo) ainda não se efetivou, o que tem feito o poder público cogitar o uso desse espaço pela Pinacoteca Municipal, sob a alegação de Carlos Calil - atual Secretário Municipal de Cultura - que "Aquele espaço não pode ficar sem uso. A cidade não pode esperar mais” (JORNAL DA TARDE, 2007, s.p.).
} 
seja, um conjunto de equipamentos que se constituíram combinando recursos públicos seja diretamente, a partir da destinação de verbas do município e da União; seja indiretamente, pela renúncia fiscal concedida às instituições privadas, por meio da Lei Rouanet (Lei Federal nº.313/91) - e recursos provenientes da iniciativa privada. Estes equipamentos culturais foram concebidos como estratégia de valorização imobiliária da região, de forma que se tornassem elementos catalisadores para novos investimentos tanto que são denominados como âncoras culturais -, bem como, para que propiciassem novos usos do espaço ou o seu consumo cultural pelas classes de maior poder aquisitivo, neste caso, os sujeitos que se espera atrair à região central.

Talvez um dos maiores exemplos das estratégias de revalorização do Centro Histórico de São Paulo, com ênfase na sua suposta valorização histórica e cultura, sejam as ações do Governo do Estado que, em 1997, empreendeu um processo de transformações da Estação Júlio Prestes para convertê-la em um complexo cultural. Assim Deste modo, no ano de 1999, o hall da antiga estação de trens deu lugar ao Complexo Cultural Júlio Prestes. Este espaço abriga a chamada Sala São Paulo (sala de concertos considerada como uma das mais modernas e bem equipadas existentes no mundo), espaços para eventos, restaurante e garagem para 600 veículos. Esse projeto, tal como analisa Kara José (2004), muito além de criar um novo lugar de lazer e entretenimento para as classes mais abastadas, se insere em um contexto de profunda transformação do bairro da Luz, colocando em lados opostos o "valioso conjunto patrimonial" e a população que ocupa a região, predominantemente, as classes populares. .

Deve-se ressaltar ainda, que a construção do Complexo Cultural Júlio Prestes consumiu aproximadamente 50 milhões de dólares, sendo a maior parte paga pelo Governo do Estado (KARA JOSÉ, 2004). A sua efetivação se deu pela formação de uma parceria público-privada articulada pela Associação Viva o Centro, envolvendo o Governo do Estado e as empresas Telefônica, Nossa Caixa e BankBoston.

Deve-se observar também que, ao mesmo tempo em que se tornou articuladora entre os agentes envolvidos na criação do Complexo Cultural Júlio Prestes, foi a Associação Viva o Centro que "forneceu" o suporte ideológico para este projeto. Deste modo, por meio da realização de diagnósticos e estudos urbanísticos sobre o bairro da Luz, a equipe técnica da Viva o Centro passou a conjecturar a respeito da existência de uma "vocação cultural" da Luz e a divulgar o desenvolvimento desse suposto potencial como "efeito indutor de qualidade urbana" para a região (ASSOCIAÇÃO VIVA O 
CENTRO, 2007, s.p.). Nesse sentido, procurou estabelecer um encadeamento entre cultura e estratégias de transformação espacial, como forma de mobilizar intervenções do poder público, bem como, o seu aporte financeiro, para criar uma dinâmica de revalorização deste espaço, que tende a beneficiar os interesses dos agentes privados que representa. De fato, como considera Arantes,

Rentabilidade e patrimônio arquitetônico-cultural se dão as mãos, nesse processo de revalorização urbana - sempre, evidentemente, em nome de um alegado civismo (como contestar?...). E para entrar neste universo dos negócios, a senha mais prestigiosa - a que ponto chegamos! (de sofisticação?) - é a Cultura. (ARANTES et alii, 2000, p. 31).

Estas considerações, portanto, se estabelecem na contramão das análises de Simões Jr. que procura enquadrar as (recentes) estratégias de intervenção no Centro Histórico como "experiências de revitalização que consideram o representativo patrimônio histórico existente no centro, e assim, possibilitam o resgate daqueles valores ligados à cultura local, ao imaginário da população e ás raízes da própria cidade" (SIMÕES JR.,1994, p. 6).

Entretanto, as evidências que se manifestam dão indícios que a valorização do patrimônio histórico, da cultura e do imaginário é instrumento para a sua revalorização imobiliária e para exercitar o consumo cultural do Centro da Cidade. Desta forma, consistem em projetos de reanimação de edifícios históricos e de sua refuncionalização, concebendo a cultura como mercadoria e como arquétipo para promover a transformação e valorização do espaço, tendo em vista o seu consumo pelas classes de maior rendimento, pelos turistas, etc.

Deve ser salientado que, uma suposta valorização do patrimônio históricocultural presente no Centro Histórico de São Paulo faz parte de uma estratégia ainda mais abrangente, que é a da revalorização deste espaço pela exaltação da sua multifuncionalidade. Deste modo, o "histórico" e o "cultural" se somam a tantas outras funções - a exemplo da função moradia - para dar configuração a um espaço cuja principal característica seria a da diversidade de atividades e funções que ele pode reunir ou concentrar. $\mathrm{O}$ que, em termos gerais, representaria uma vantagem locacional da região central, frente à concorrência com as centralidades modernas ${ }^{27}$, pela atração

\footnotetext{
${ }^{27}$ Neste caso, se tem como referência a avenida Paulista e a centralidade composta pela avenida Luiz Carlos Berrini.
} 
de novos investimentos privados, bem como, por atrair novos contingentes populacionais.

Conforme afirma Alves, os centros novos surgem como espaços altamente especializados, ou seja, "reúnem, de acordo com a sua especificidade, os elementos essenciais ligados ao desempenho de suas funções, de forma a atenderem às exigências dadas por sua funcionalidade..." (ALVES, 1999, p. 18). No geral, se especializam como Centros empresariais, financeiros e tecnológicos. Em oposição a essas centralidades, o Centro Histórico passa ser evocado como espaço de concentração da diversidade, ou seja, como o lugar onde se pode realizar o trabalho, a moradia, o encontro com a história e a cultura. Em suma, o espaço da multifuncionalidade. Embora o discurso procure distinguir uma e outra centralidade, a finalidade da produção de ambas não parece ser diferenciada, ou seja, tanto o Centro Histórico, como as novas centralidades, são espaços produzidos para a reprodução do capital.

O que esse discurso pretende criar, por meio da exaltação de uma certa multifuncionalidade do Centro Histórico de São Paulo, é uma estratégia de marketing para vender o espaço aos agentes econômicos da cidade. Deste modo, o Centro, a sua multifunção e a sua história, se tornam produtos ou mercadoria para o consumo da sociedade capitalista.

É neste contexto de exaltação de uma pretensa multifuncionalidade do Centro Histórico de São Paulo que são traçados planos visando o reforço da função habitacional deste espaço. Como será possível investigar, a partir da análise das políticas e projetos elaborados pelas diferentes gestões que administraram São Paulo a partir da década de 90, o problema da habitação se torna uma questão recorrente nos planos de revalorização do Centro Histórico. No entanto, é necessário, considerar que este problema vai ganhar diferente tratamento em cada uma dessas gestões.

A concepção geral que envolve as políticas de reforço habitacional do Centro de São Paulo procura apontar que habitá-lo ou fortalecer a sua condição de espaço de moradia na cidade é uma das formas de garantir sustentação ao seu projeto de revalorização. O ponto de convergência para essa discussão passa a ser o entendimento de que um processo de esvaziamento populacional, em curso na região central da cidade $^{28}$, tem contribuído fortemente para o abandono e o desuso dos equipamentos urbanos lá existentes. Portanto, atrair novos moradores para esta porção da cidade

\footnotetext{
${ }^{28}$ Mais adiante serão apontados os números que dão comprovação para esse fato.
} 
poderia representar, de um lado, uma perspectiva de racionalizar os próprios investimentos do Estado, gerando um maior aproveitamento da infra-estrutura consolidada, bem como dos serviços públicos existentes (principalmente no período noturno, quando parte da população que permaneceu no Centro ao longo do dia faz o movimento de retorno para os bairros). Chega-se a ensejar, também que, o estímulo ao uso habitacional do centro pode ser um elemento de controle à expansão periférica da cidade, neste sentido, como afirma Silva, H.:

$\mathrm{O}$ aumento da oferta habitacional no centro permitiria reduzir a pressão sobre o sistema metropolitano de transportes, otimizar a infraestrutura e os equipamentos já instalados e evitar que a cidade continue a expandir ou adensar-se em área com precariedade de infraestrutura, especialmente sobre áreas de proteção ambiental (SILVA, H., 2001, p. 1).

Todavia esta última prerrogativa só vem a ser considerada nas políticas de reforço habitacional do Centro difundidas pelas gestões municipais de caráter mais progressista, que, ao menos no nível do discurso, procuram manifestar que uma política habitacional deve estar articulada ao conjunto de intervenções públicas e privadas para a revalorização do Centro, como forma de garantir às classes que trabalham e moram nesta região a sua permanência. Tal como sugerido pelo poder público na gestão Marta Suplicy:

Além da oferta de infra-estrutura, acessibilidade e oportunidades de trabalho, o Centro apresenta potencialidade para a produção de unidades habitacionais, como a existência de terrenos vazios, de edifícios passíveis de reforma ou reciclagem, de edifícios de valor arquitetônico ou histórico, para os quais a melhor alternativa de recuperação e manutenção é a reabilitação para o uso habitacional (SÃO PAULO, 2004, p. 6).

De alguma forma, essas prerrogativas procuram contemplar as demandas que são colocadas pela população de baixa renda organizada, em parte, em torno dos movimentos de moradia do Centro da cidade. Esses movimentos, por sua vez, passaram a pressionar o Estado e a insistir na defesa pela habitação popular na região central, tendo como justificativa o déficit habitacional existente no município e o elevado número de imóveis vazios ${ }^{29}$, bem como, as desvantagens de viver na periferia, lugar onde geralmente são efetivados os programas de habitação popular.

\footnotetext{
${ }^{29}$ Segundo estimativa do poder público municipal, seria necessária a provisão de aproximadamente 600 mil domicílios para suprir o déficit habitacional existente na cidade de São Paulo (SÃO PAULO, 2003). Já os dados divulgados pelo IBGE referentes ao ano de 2000 indicam haver em São Paulo 420.327 domicílios particulares vagos, dos quais 45.464 somente nos distritos Sé e República (IBGE, 2001).
} 
Entretanto, o horizonte de efetivação desses intentos parece estar longe de se concretizar, isso porque o discurso que tende a se tornar hegemônico, e que, em geral, é melhor aceito e reproduzido pelo poder público, é aquele que procura negar o Centro como espaço de habitação das classes populares e, por outro lado, caminha para a defesa do reforço habitacional da região central, porém, para classes médias ou altas, na esteira de um novo dinamismo do mercado imobiliário na região.

Esta orientação, no que tange ao uso habitacional do centro pelas classes de maior renda, ganha relevo em um outro discurso que emerge como fruto de estratégias do poder público - nas gestões mais conservadoras e à direita - afinadas com os interesses das instituições privadas. Neste caso o estímulo à moradia no Centro passa a ser difundido - nunca de modo explícito - como um elemento estratégico para a sua revalorização, deste modo, decisivo para gerar a mudança do uso que se faz do Centro da cidade, ou melhor, do perfil social do seu usuário. Não raro se faz referência aos processos ocorridos em bairros de Nova Iorque, como Soho, UpperWest Side, onde a valorização do espaço foi promovida por meio da conversão de velhos edifícios em novas habitações e pela criação de um cenário cult, que se tornou possível pela presença de artistas e intelectuais que lá aportaram nos anos $70^{30}$. Neste caso, considerase que os novos moradores se tornaram agentes da recuperação de um espaço anteriormente degradado.

No caso paulistano, procura-se propagandear a idéia de um "uso residencial socialmente diversificado" no Centro de São Paulo - como defendido pela Associação Viva o Centro -, que associaria as demandas das classes populares com a presença das classes médias ou de outras camadas de maior poder aquisitivo. Entretanto, o que parece se evidenciar é o interesse pela atração de um novo morador que venha a se constituir como um consumidor em potencial dos novos serviços a serem oferecidos. Do mesmo modo, espera-se que a presença constante desse novo morador se desdobre em ações de zeladoria urbana - para não dizer vigilância e controle do uso do espaço - pressionando o poder público para manutenção constante da área e para novos investimentos neste espaço.

${ }^{30}$ Em geral, estas mesmas referências desconsideram que revalorização destes bairros só ocorreu mediante a expulsão dos antigos moradores, e que, mesmo hoje, em função da extrema valorização imobiliária destas áreas, parte desses "artistas" teve que se retirar. Sendo assim, o cenário cult continua a existir, porém, estes bairros se tornaram reduto para consumo e moradia dos chamados yuppies (grupos de média ou alta renda, conhecidos por serem consumidores vorazes e ciosos por luxo e conforto, bem como, extremamente preocupados com o seu status social). 
No curso da análise do processo de revalorização do Centro Histórico de São Paulo, não se pode perder de vista que, embora as estratégias políticas que o determinam sejam definidas no âmbito do Estado, elas estão suscetíveis a uma série de interferências, principalmente àquelas provenientes das instituições privadas. Estas instituições atuam procurando pressionar o poder público para a contemplação das suas demandas particulares. De um lado buscam garantir as condições propícias para manter os seus investimentos sempre valorizados, e do outro procuram meios para realização de novos e lucrativos negócios no Centro da cidade.

Em geral, o poder público declina à pressão e aos interesses desses agentes, compactuando com os mesmos.

Estes interesses são representados, em sua grande parte, pela Associação Viva o Centro, que desde o ano de 1991, tem cumprido um dos papéis centrais no processo de revalorização da região central, pois mantém uma participação efetiva junto às instâncias de decisão e poder municipal, orientando, por meio do seu discurso, algumas das estratégias de intervenção do Estado.

A revalorização do Centro Histórico, sendo assim, comandada pelo poder público aliado aos interesses da iniciativa privada, já tem materializado no espaço alguns dos seus resultados. Dentre eles: a recuperação da fachada de prédios antigos; a restauração completa e refuncionalização de alguns edifícios históricos; a reforma de ruas, praças e calçadas; abertura dos calçadões para viabilizar o trânsito de veículos; a definição de políticas para a atração de novos investimentos privados baseadas, geralmente, na isenção de tributos públicos; o controle do uso do espaço, por meio da sua vigilância extensiva; a repressão ao comércio ambulante, etc. Some-se a estes resultados, o retorno do Estado e de parte das suas secretarias para o Centro da cidade.

O conjunto destas transformações passa a ser justificado pelo próprio Estado por meio de um discurso que afirma a necessidade de reordenar o uso do espaço e a inversão de dinheiro público em obras de melhorias urbanas para criar elementos que animem futuros investimentos da iniciativa privada. A estratégia em questão procura demonstrar que, é a partir da intervenção e investimento do Estado que terá início um movimento de sinergia que atrairá novas melhorias e investimentos de capital privado. Esse discurso, entretanto, encobre uma estratégia clara do poder público em propiciar às instituições privadas os meios satisfatórios que permitam a plena reprodução do seu capital. 
Associado a essas "garantias" o Estado põe à disposição da iniciativa privada a possibilidade de modificação e/ou revisão do conjunto de normas que regem o uso do solo urbano no Centro de Cidade, visando facilitar a construção de novos empreendimentos, por meio da flexibilização do zoneamento da cidade. Este é o caso das chamadas Operações Urbanas ${ }^{31}$, que permitem a venda e compra de potencial construtivo acima dos índices fixados pela lei de zoneamento, cabendo ao comprador, retribuir o benefício por meio do pagamento de uma contra-partida financeira, que será reinvestida na região.

Tal como é possível encaminhar, se às instituições privadas estão abertas as possibilidades para a apropriação do Centro Histórico, essas mesmas possibilidades não estão asseguradas aos cidadãos. Podendo-se pressupor que, à medida que o processo de revalorização vai se concretizando, o uso do espaço tende a ser negado à boa parte da população. Pois, associada à transformação e reordenação do espaço são tomadas medidas que buscam exercer o controle sobre o seu uso, tornando-o seletivo ${ }^{32}$ e vigiado. São exemplos dessas estratégias: a concepção de novos espaços culturais, cujo acesso é, na maior parte das vezes, pago; o monitoramento do Centro por câmeras de vídeo, que permitem à Guarda Metropolitana ter controle das ações no espaço público, e reprimir comportamentos considerados inadequados, tais como: a permanência nas praças públicas da população de rua, dos ambulantes, etc.

$\mathrm{Na}$ prática, estratégias como essas tendem a suprimir aquilo que o Centro apresenta de mais dinâmico: a aproximação e o convívio entre os diferentes; a imprevisibilidade dos acontecimentos e ações; a possibilidade de transgressão às normas; a livre manifestação; o livre acesso ao espaço público; e o seu uso pleno pela coletividade. Dessa maneira, tudo o que garante vitalidade à região central é captado pelos agentes da revalorização para dar conteúdo a um discurso que, elaborado a partir de uma representação do espaço, passa a definir o Centro como o lugar da insegurança, da inadequação dos atos e da deterioração, para, por outro lado, afirmar a sua urgente transformação e reordenação. Ao encontro dessas considerações é que pode ser compreendida a afirmação de Marco Antonio R. de Almeida ${ }^{33}$, ao dizer que "Ele [o

\footnotetext{
${ }^{31}$ A exemplo da Operação Urbana Centro.

${ }^{32}$ Leia-se, segregado.

${ }^{33}$ Presidente da Diretoria Executiva da Associação Viva o Centro.
} 
Centro Histórico] sempre foi pleno de vitalidade. Vitalidade essa que necessita apenas ser requalificada, reordenada, refuncionalizada" (ALMEIDA, 2001, p. 9).

Portanto, muito além do entendimento que pode ser feito do processo de revalorização do Centro Histórico como um conjunto de medidas visando intervenções de caráter urbanístico para alteração da paisagem, pela promoção da "diversidade social", pela "valorização da cultura", evidencia-se que as estratégias e práticas definidas parecem indicar que as transformações pretendidas para o Centro não se realizam sem incidências sobre o uso e a apropriação do espaço pela população, procurando torná-los controlados, seletivos e ordenados. Segundo Alves:

É no Centro da cidade que se materializa o ponto de intercâmbio entre as necessidades de reprodução do capital, que tendem a ser gestadas pelas leis de mercado e, por isso, exigem do poder estatal e dos empreendedores privados, ações estratégicas para o controle sócioespacial, e o desejo de apropriação por parte da população da vida urbana, que nas áreas do centro estão marcadamente presentes (ALVES, 1999, p.18).

Este controle sócio-espacial tende a se tornar efetivo e mais rigoroso, pois a população que se quer sujeitar com estas ações é a aquela que questiona e se opõe ao processo de revalorização do Centro Histórico e, ao mesmo tempo, faz lembrar aos novos usuários ou consumidores do espaço que a produção do novo cenário não se realiza sem antes criar segregações e estimular a desigualdade social.

Conquanto, tanto o poder público - no papel da Prefeitura Municipal - como a iniciativa privada - representada pela Associação Viva o Centro - sustentem o discurso que o processo de revalorização do Centro Histórico de São Paulo tem como uma de suas frentes reforçar a função habitacional deste espaço contemplando, a diversidade sócio-econômica da sua população, a análise que será feita das políticas públicas e das estratégias já definidas por estes agentes pode sugerir um cenário que, na maior parte das vezes, diverge deste discurso. Não só diverge, como parece apontar para a impossibilidade de atribuir um caráter de diversidade social às propostas de habitação feitas para o Centro Histórico de São Paulo no contexto do seu processo de revalorização. Segundo Frúgoli Jr.:

Há uma tendência em se considerar [tal como faz a consultoria urbanística da Associação Viva o Centro] que os pobres realizam uma ocupação residual dos espaços urbanos, o que explicaria em parte sua presença na área central. Além disso, há o diagnóstico de um sistema de transporte coletivo irracional, convergindo excessivamente para o Centro, o que produziria, por sua vez, uma presença popular em massa desnecessária na região - porque simplesmente de passagem. Uma 
reorganização desse sistema incidiria sobre essa massa, distribuindo-a para outras regiões, o que dessa forma poderia reduzir tanto a mendicância, quanto o comércio informal. Isso propiciaria, por consequiência, o atendimento do verdadeiro interesse popular, entendido como os empregados das empresas - que constituem, por sinal, um habitual público-alvo de revitalizações urbanas em metrópoles do Primeiro Mundo (FRÚGOLI JR., 2000, p. 225-226, grifos do autor).

Estas constatações podem sugerir mais uma vez que, associado a um processo de revalorização do Centro Histórico de São Paulo, baseado em investimentos do poder público para dotar de novas infra-estruturas esta centralidade e proporcionar uma valorização do patrimônio lá existente, adotam-se estratégias para atribuir outra vitalidade a esta área, cujo uso e apropriação seria compatível com a renda daqueles segmentos de maior poder aquisitivo da sociedade, capazes de consumir os novos serviços a serem ofertados no Centro, bem como, demandar por novas atividades - tais como, centros culturais, cafés, restaurantes sofisticados, entre outros -, que, ao se realizarem, contribuiriam para a revalorização deste espaço.

Embora a função habitação seja privilegiada no atual processo de revalorização do Centro, as políticas desenvolvidas nesse sentido tendem a reforçar o cumprimento desta função como atributo do mercado imobiliário. O Estado termina por conceder estímulos ao mercado de habitação privado, visando a construção de edifícios ou readequação das construções antigas para a produção de novas moradias. Neste caso, atendendo à demanda de uma parcela da população que dispõem de recursos financeiros para adquirir esta propriedade ${ }^{34}$.

Neste sentido, se pressupõe que as estratégias para reforço da função moradia no Centro de São Paulo não só garantem aos agentes imobiliários novas possibilidades de acumulação de capital, por meio da produção e comercialização da habitação, como também restringem o uso habitacional à determinadas classes da população. Indicando a clara intenção de promover um novo adensamento da região central por meio da atração de setores da classe média e alta, em detrimento da população de baixa renda, que hoje se apresenta em número significativo nesta região.

Embora existam políticas para a promoção de Habitação de Interesse Social no Centro de São Paulo, como será possível analisar, estas se mostram insuficientes para atender a grande demanda da população de baixa renda que lá já vive. Por outro lado, o poder público não se exime em densificar a periferia da cidade com a construção de

\footnotetext{
${ }^{34}$ Esta discussão será retomada com mais especificidade ao longo deste trabalho.
} 
conjuntos habitacionais e loteamentos populares em áreas que, além de distantes da região central, apresentam limitada infra-estrutura e acesso aos serviços públicos.

Em torno da reivindicação pelo direito à habitação no Centro da cidade, na década de 1990 se organizaram alguns movimentos sociais, como o Movimento dos Sem Teto do Centro - MSTC, que procuram meios de pautar o poder público e a sociedade com a sua demanda por moradia na região central. Estes movimentos procuram dar visibilidade social às suas reivindicações por meio da ocupação dos edifícios vazios e ociosos existentes no Centro da cidade, pressionando o Estado a tomar iniciativas para a sua desapropriação e conversão em habitação popular.

Como meio de articulação dos movimentos de moradia e demais entidades sociais que começam a surgir no Centro da Cidade, constituiu-se no ano de 2000 o Fórum Centro Vivo. Este Fórum compõe um espaço de discussão e de engajamento entre os diferentes movimentos sociais que, em geral, se opõem ao processo de revalorização do Centro Histórico de São Paulo e reivindicam a apropriação deste espaço pela população de baixa renda. Pode-se dizer que a sua ação se faz como contraponto à atuação da Associação Viva o Centro.

O Fórum Centro Vivo é um espaço onde se congregam os vários movimentos para discutir os seus problemas específicos e aqueles relativos ao Centro da cidade, como forma de estabelecer uma agenda única de ação e de reivindicação. O Fórum busca, deste modo, ampliar a pressão sobre o Estado e gerar interferências no rumo do processo de revalorização do Centro Histórico de São Paulo.

O embate entre o poder público, a Associação Viva o Centro e os movimentos que compõem o Fórum Centro Vivo é emblemático de que em torno do processo de revalorização do Centro Histórico se circunscrevem conflitos de interesse. Esses conflitos se estabelecem como luta pela apropriação do espaço. Neste sentido é possível pressupor que Viva o Centro procura se apropriar desse espaço como forma de garantir os meios para a reprodução do capital que representa, tendo, para isso, o aval do Estado; os movimentos sociais, por meio do Fórum Centro Vivo, buscam uma apropriação do espaço pela afirmação do seu valor de uso e para a reprodução da vida.

Entretanto, a tendência que parece se firmar no processo de revalorização do Centro Histórico de São Paulo é aquela da adaptação deste espaço às exigências do capital $^{35}$. Tal como foi apresentado na introdução desta dissertação, a hipótese dessa

\footnotetext{
35 Esta afirmação converge com as constatações já realizadas por Alves (1999, 2004, 2005) e Carlos (2004).
} 
pesquisa é que, no intuito de promover esta revalorização, as estratégias comandadas pelo Estado em direção aos interesses da iniciativa privada ao se concretizarem não se realizam sem prejuízos à forma como as classes populares habitam neste espaço.

Segundo Carlos,

[...] o modo pelo qual o uso [do espaço] se dará dependerá dos condicionantes do seu processo de produção. No caso da sociedade capitalista estará determinado pelo processo de troca que se efetua no mercado, visto que o produto capitalista só pode ser realizado a partir do processo de apropriação privada (CARLOS, 1997, p. 27).

Neste sentido, se a apropriação do espaço tende a se restringir à posse da propriedade, ou ainda, se as relações de troca se tornam o meio possível para a realização do uso do espaço; na revalorização do Centro Histórico seria possível vislumbrar estratégias que não primassem pelo distanciamento em relação aos interesses da população pobre ou de baixa renda?

Nesta direção é que se reafirma como pressuposto que, atualmente, quando se propõe uma estratégia de revalorização do Centro Histórico de São Paulo busca-se para lá atrair um tipo de morador cuja presença contribua para o fortalecimento da imagem do Centro como um lugar seguro, higiênico e habitável. Deste modo, as ações empreendidas pelo Estado e a iniciativa privada parecem caminhar no sentido de beneficiar as classes de maior rendimento em detrimento da população pobre.

Este fato parece apontar para uma tendência segregacionista nos atuais projetos de revalorização, o que a princípio, contraria os pressupostos normativos do Estatuto da Cidade ao limitar ou impedir o "uso da propriedade urbana em prol do bem coletivo" (Cap. 1, par. Único).

O Estatuto da Cidade é a lei que regulamenta os artigos de política urbana da Constituição Federal de 1988 e define os princípios, as diretrizes e os instrumentos de gestão da cidade, atribuindo aos municípios a função de estabelecer - mediante a elaboração de um plano diretor - as condições para o cumprimento da função social da propriedade e da cidade. Como consta na Lei Federal nº 10.257 , o Estatuto estabelece "normas de ordem pública e interesse social que regulam o uso da propriedade urbana em prol do bem coletivo, da segurança e do bem-estar dos cidadãos bem como do equilíbrio ambiental" (Cap. 1, par. Único).

Dentre os instrumentos de política urbana do Estatuto da Cidade pode-se citar: o "parcelamento, edificação ou utilização compulsórios", o "IPTU progressivo no tempo", a "desapropriação com pagamento em títulos da dívida pública", as "operações urbanas 
consorciadas", a "participação da população na definição da política urbana", entre outros.

Os setores que hoje defendem o direito à moradia para as classes populares da cidade de São Paulo consideram que a formulação do Estatuto da Cidade responde a estas necessidades ao garantir o combate à especulação imobiliária; a recuperação para a coletividade da valorização imobiliária; e a participação da população na formulação e execução das políticas públicas. No entanto, "é necessário dialetizar seu papel [do Estatuto da Cidade] na constituição de um projeto capaz de sinalizar as transformações necessárias da cidade como momento de transformação radical da sociedade" (CARLOS, 2004, p. 143). Isto se justifica, não somente pelo caráter, ainda, contingente do Estatuto, mas também, pela possibilidade de desvios interpretativos aos quais ele se abre. Como afirma Maricato:

Esses e outros instrumentos existentes têm a orientação de sua aplicação (ou suspensão de sua aplicação) dada pela correlação de forças [...]. Nenhum instrumento é adequado em si, mas depende de sua finalidade e operação. Nenhuma virtualidade técnica substitui o controle social sobre essa prática (MARICATO, 2001, p. 96).

Desta forma, reafirma-se a necessidade de analisar dialeticamente o Estatuto da Cidade, porque em um contexto de evidentes conflitos sociais, onde os interesses dos diferentes grupos que lutam pela apropriação ou pela dominação do espaço tendem a divergir, os impactos da aplicação ou efetivação da lei podem abrir outras possibilidades além daquelas para as quais, ao menos enquanto proposta formal, ela foi elaborada.

\subsection{Revalorização do Centro Histórico: retomando algumas premissas}

A revalorização do Centro Histórico de São Paulo está intrinsecamente ligada à expansão da centralidade nesta cidade, com a constituição de centros cada vez mais modernos e aptos a atender as demandas dos agentes econômicos. Este movimento de expansão tem origem nos anos 60, quando se inicia um processo de evasão de parte das sedes de empresas e bancos, que se deslocaram do Centro tradicional em direção à nova centralidade em constituição, isto é, à região da avenida Paulista. A formação desta nova centralidade é contemporânea ao desenvolvimento, em São Paulo, das atividades ligadas aos serviços, ao comércio e às finanças - o setor econômico terciário.

Este processo ganha um novo impulso a partir do final da década de 70, com a abertura de novas avenidas na região sudoeste da cidade (nas proximidades da Marginal 
Pinheiros), amplamente paramentadas e a serviço do que passou a se denominar por setor terciário avançado (FIX, 2001), ou seja, empresas transnacionais que atuam principalmente no setor de serviços e de gestão empresarial, empregando, para a realização da sua atividade, recursos altamente tecnológicos e, por isso, demandando por infra-estruturas modernas que proporcionem o dinamismo necessário a essas atividades.

Os novos centros passaram a atrair parte daquelas atividades que eram desenvolvidas preferencialmente no centro tradicional da cidade e a cumprir uma série de outras funções que, frente as novas demandas dos agentes econômicos, necessitam de espaços com infra-estrutura moderna, flexível e que propiciem eficiência ao processo produtivo. A realização destas atividades, por sua vez, implicaria uma mudança nas estruturas espaciais existentes no Centro Histórico, o que não seria possível de se realizar, àquela época, devido às limitações físicas deste espaço ou ao seu caráter rígido. Neste caso, refere-se especificamente à quase inviabilidade de criar ou de adaptar as estruturas existentes na região central com uma série elementos - tais como, redes de fibra ótica, edifícios inteligentes, etc. - que se tornaram indispensáveis frente aos novos requisitos de eficiência produtiva em tempos de globalização econômica.

Deste modo, mesmo que momentaneamente, o Centro Histórico passa ser considerado como um lugar-entrave à reprodução capitalista, cuja plenitude só poderia ser alcançada por meio da produção de novos espaços na cidade. Entretanto, a constituição desses novos espaços para o capital, não se realiza sem gerar, simultaneamente, a desvalorização ou deterioração das áreas anteriores. Este é o caso do Centro Histórico de São Paulo, desvalorizado frente as novas possibilidades de reprodução a partir da expansão desta centralidade em direção à região sudoeste da cidade.

Embora esta desvalorização não tenha se convertido em termos do barateamento do preço do solo $^{36}$ no Centro de São Paulo, ela se processou em função da diminuição do dinamismo econômico da região, como resultado do afluxo dos investimentos públicos e privados para a produção de novas áreas da cidade. Neste sentido, diversos setores da economia migraram em direção às novas centralidades. Se já havia sido destacada a evasão no Centro Histórico das sedes de empresas e bancos, é importante

\footnotetext{
${ }^{36} \mathrm{O}$ Centro é hoje a terceira zona mais valorizada de São Paulo, com preço médio de $\mathrm{R} \$ 2.453$ por $\mathrm{m}^{2}$ útil, enquanto a zona sul e a zona oeste apresentam, respectivamente, preços médios de $\mathrm{R} \$ 2.769$ e $\mathrm{R} \$$ 3.116 por $\mathrm{m}^{2}$ útil (FOLHA DE SÃO PAULO, 2004b).
} 
enfatizar que este processo se realizou com notoriedade para aqueles setores ligados à atividade imobiliária e à construção civil, que encontraram na expansão do Centro de São Paulo uma estratégia rentável e de grande vitalidade para os seus negócios.

Como mostra o caso da construção da avenida Engenheiro Luís Carlos Berrini, a produção desta nova centralidade (em fins da década de 70) se concretizou segundo a possibilidade de incorporação de áreas de baixo valor da cidade (que não faziam parte da estratégia de reprodução e valorização do capital), por meio da atuação combinada do Estado, dos capitais imobiliário e financeiro e do setor construtivo, extraindo desta atividade ganhos imensuráveis (FIX, 2001).

De acordo com Vargas (2006), o êxodo de atividades do Centro Histórico de São Paulo constitui uma causa de origem externa para a sua desvalorização, e que estaria associado, entre outros, à concorrência com outras áreas da cidade que passaram a apresentar vantagens em relação a sua oferta imobiliária, a sua infra-estrutura e tecnologia. Além disso, como efeitos internos da deterioração, Vargas referencia: “congestionamento de trânsito, poluição do ar, poluição visual, [...] preço do solo, escassez de áreas, falta de estacionamentos..." (VARGAS, 2006, p. 1). Conforme foi observado anteriormente, a superação desta deterioração (das suas causas) passa ser a condição sine qua non para a revalorização do Centro, tal como sugere o discurso do poder público municipal e da Associação Viva o Centro.

É necessário salientar ainda que pela ação conjunta das chamadas causas internas e externas da desvalorização do Centro foi que se tornou possível a fixação na região central das classes populares. Isto porque, associado a um movimento de transferência de parte das atividades econômicas, culturais, assim como de órgãos do poder público municipal, ocorreu, também, a evasão de parcelas da população de maior poder aquisitivo em direção a outras regiões da cidade. Deste modo, as residências e edifícios abandonados passaram, parcialmente, as ser incorporados pelas classes de menor renda como espaços para sua moradia.

Neste momento - entre os anos 60 e 70 - ocorre um processo que alguns autores ${ }^{37}$ denominam por "popularização" do Centro, que se refere à migração e fixação na região central das classes de menor rendimento. Pode-se afirmar que o movimento de retirada das classes de maior poder aquisitivo em direção ao entorno da Avenida Paulista abriu a possibilidade de uma nova configuração sócio-espacial da região

\footnotetext{
${ }^{37}$ Dentre eles, Frúgoli Jr. (2000) e Rolnik (2002).
} 
central, porque gerou, em contrapartida, o aumento da ocupação do Centro Histórico paulistano pelas classes populares.

Na sua origem, o que se denomina por Centro Histórico constituía o espaço de concentração das funções religiosas, administrativas, comerciais e também residenciais da população mais abastada. Segundo Rolnik:

A virada do século XIX para o século XX é o momento de construção, na cidade de São Paulo de uma ordem urbanística caracterizada por uma região central investida pelo urbanismo, destinada exclusivamente às elites, contraposta a um espaço puramente funcional, normalmente sem regras bem fora desse centro, onde se misturam o mundo do trabalho e o da moradia dos pobres (ROLNIK, 2002, p. 17, grifos da autora).

Por outro lado, mesmo que esta "ordem urbanística" seja característica da produção do espaço da cidade de São Paulo até os dias de hoje, no caso específico do Centro Histórico, é possível afirmar que, a partir dos anos 1960, quando do início da sua apropriação pelas classes populares, foram lançadas as bases para a reversão do uso desse espaço estritamente pelas classes de maior poder aquisitivo ${ }^{38}$.

Parte desta população mais pobre que se deslocou para o Centro buscava satisfazer suas necessidades específicas de trabalho, lazer e moradia, mas, por conta das suas limitações econômicas, instalou-se coletivamente em antigos casarões, outrora, abandonados - os chamados cortiços ${ }^{39}$. De acordo com Silva, H., é somente nos cortiços que se torna viável a instalação na região central das classes populares, pois representam moradias que "não encontram outro uso mais rentável... [e constituem] uma atividade extremamente lucrativa para os seus proprietários [...] rendendo mais que os aluguéis formais para uso residencial ou comercial" (SILVA, H., 2000, p. 9).

Como uma forma de habitação recorrente na cidade de São Paulo ${ }^{40}$, os cortiços representam, ainda hoje, uma parcela significativa das moradias presentes no Centro

\footnotetext{
${ }^{38}$ A "popularização" do centro pode ser igualmente justificada pela instalação, neste mesmo período, dos terminais de ônibus e ramais do metrô, que tornaram o Centro Histórico mais acessível à população da cidade.

${ }^{39}$ Pode ser definido por cortiço: "Habitação coletiva composta de unidades domiciliares alugadas no mesmo lote urbano onde coabitam famílias e/ou pessoas sós ou associadas, quase sempre sem contrato formal de locação; Uso comum, por diferentes grupos, no todo ou em parte, de áreas de acesso comum e de equipamentos sanitários (banheiro, cozinha, tanque), com conseqüente ausência de privacidade; Congestionamento ou número elevado de usuários por área/cômodo/equipamento; Empreendimento explorado pelo proprietário do imóvel ou por locatário/sublocador. Precariedade da construção (estado de conservação) das unidades domiciliares e do imóvel como um todo e das instalações elétricas e hidráulicas..." (SÃO PAULO, 2003, p. 28).

${ }^{40}$ O Centro Histórico de São Paulo, desde o final do século XIX, registra a existência de cortiços para atender a demanda de moradia da população de baixa renda.
} 
Histórico paulistano; e tal fenômeno pode ser explicado pela infra-estrutura e os meios de consumo coletivos aí existentes (RODRIGUES, 1994). Entretanto, diante da iminência de um processo de revalorização do Centro Histórico de São Paulo, a permanência da população encortiçada nesta região passa a ser colocada em xeque. Isso porque os interesses que tendem a prevalecer neste processo, conforme já foi possível apontar, são, em sua maioria, aqueles que defendem um adensamento do Centro com habitações voltadas aos setores de maior poder aquisitivo. Nesta mesma perspectiva, os programas para habitação de interesse social, quando não se mostram insuficientes para atender a demanda da população de baixos rendimentos, passam a ser amplamente criticados pelos setores hegemônicos que defendem, mesmo que indiretamente, a localização deste tipo de habitação fora das áreas de valorização imobiliária, ou seja, fora de áreas como o Centro Histórico da cidade de São Paulo.

Do mesmo modo, pode-se observar que pautada na deterioração do Centro Histórico de São Paulo, erige-se uma estratégia de classe que procura tornar legítima, por meio da associação que faz entre esta deterioração e o uso do espaço pelas classes populares (FRÚGOLI JR., 2000), uma cobrança sobre o Estado por medidas que limitem e disciplinem o acesso desses cidadãos aos espaços públicos. Neste caso, o deteriorado deixa de ser propriamente o espaço e passa a ser aquele que faz uso dele.

Ainda no que diz respeito à expansão da centralidade, pode-se afirmar que, já nos anos 60, a região da Avenida Paulista passou a ser considerada o novo centro paulistano, e se tornou área de atração de grande parte dos investimentos públicos e privados que antes eram alocados, quase que exclusivamente, no Centro Histórico de São Paulo.

Deste modo, além atrair os investimentos, a nova centralidade passou a abrigar também, parte das atividades de cultura e lazer da cidade. Do mesmo modo, passou a dividir com o Centro Histórico o papel de lugar de comando e de concentração de poder político de São Paulo. Embora isso tenha representado uma diminuição da força política e econômica do Centro tradicional, ele ainda se constitui como lugar preferencial de ocorrência de determinados serviços, como aqueles ligados à administração pública e à atividade financeira (como a Bolsa de Valores de São Paulo e a Bolsa de Mercadorias e Futuros que estão localizadas no Centro Histórico $)^{41}$.

\footnotetext{
${ }^{41}$ Talvez por isso as novas centralidades ainda mantenham com o Centro mais antigo, uma relação de complementaridade e relativa dependência.
} 
Frente à ensejada revalorização do Centro Histórico, o poder público aliado aos interesses da iniciativa privada passa a definir planos para recuperar algumas das antigas funções que esta região exercia, reafirmar parte daquelas que ainda lá se realizam e atrair as novas atividades ${ }^{42}$ que são privilegiadas no atual movimento de reprodução capitalista. Não faltam ideologias a amparar e legitimar estes planos, dentre elas, podese reconhecer aquela que afirma por uma "necessária" inclusão da cidade de São Paulo no hall das chamadas cidades globais ${ }^{43}$.

Deve-se apontar que com o advento da Globalização, os agentes econômicos superaram as suas fronteiras nacionais e passaram a atuar simultaneamente em diferentes lugares do mundo (o que se tornou possível frente ao desenvolvimento das novas tecnologias da informação), porém, preferencialmente naqueles lugares onde as garantias para a sua atuação estão ofertadas. Nesse aspecto incluem-se, além das infraestruturas modernas, investimentos em pesquisas e inovação, os incentivos fiscais concedidos pelo Estado, uma massa de mão-de-obra de baixo custo e disposta a grandes jornadas de trabalho, etc. Constituem-se, portanto, as chamadas cidades globais. Segundo Sassen:

[...] as cidades globais da atualidade são: (1) pontos de comando da organização da economia mundial; (2) lugares e mercados fundamentais para as indústrias de destaque do atual período, isto é, finanças e os serviços especializados destinados às empresas; (3) lugares da produção fundamentais para essas indústrias, incluindo a produção de inovações (SASSEN, 1998, p. 16).

Deste modo, trata-se da produção de espaços propícios para a reprodução do capital internacional. Contudo, cabe ao poder público (local) mobilizar, para esse feito, uma gama de recursos (em geral, públicos) para a realização de estratégias de intervenção no espaço urbano, buscando com isso criar formas espaciais que atendam aos requisitos de eficiência e de qualidade demandados pelos agentes econômicos. Encerrado nesta estratégia, o espaço nada mais pode ser do que produto para o consumo dos próprios setores hegemônicos. Como afirma Lefebvre, "Há poucos anos não se podia imaginar outra produção que não fosse a de um objeto [...] Hoje o espaço inteiro entra na produção como produto através da compra, da venda, da troca de parcelas do espaço" (LEFEBVRE, 1999, p. 142, grifo do autor).

\footnotetext{
${ }^{42}$ A exemplo das atividades comerciais, de serviços e finanças.

${ }^{43}$ No discurso do poder público e da Associação Viva o Centro esse conceito aparece designado por "cidades mundiais".
} 
A revalorização do Centro Histórico passa a ser colocada como estratégia ideal para a construção de uma imagem competitiva de São Paulo no mercado internacional das cidades globais, que concorrem incessantemente pela atração de novos investimentos. O poder público municipal - amparado aos propósitos da Associação Viva o Centro - chega a ponto de proclamar a região central como o lugar a partir do qual é possível articular São Paulo à esfera das economias globais, bastando, para isso, reforçar a sua condição de centralidade principal da cidade e superar a sua situação de deterioração.

Estas considerações parecem ter correspondência direta às asserções de Ascher, ao prenunciar que:

As grandes metrópoles confrontam-se cada vez mais diretamente com a concorrência urbana internacional. Elas precisam atrair investimentos internacionais [...] Para tanto devem dispor de um ou mais centros bem conectados aos sistemas internacionais, capazes de acolher as funções econômicas estratégicas e as atividades comerciais de alto nível. Entretanto, seu centro é geralmente pouco adaptado a essas funções, seja por estar fortemente desqualificado, material socialmente, seja, ao contrário por estar asfixiado por altas densidades e trânsito automobilístico [...] A isto acrescenta-se muitas vezes a preocupação legítima de permitir que as populações pobres que nela residem possam ali permanecer, o que evidentemente não facilita a constituição das nova centralidades metapolitanas (ASCHER, 2001, p. 62-63).

Deste modo, parece haver um desígnio a ser cumprido pelas cidades: a produção de uma centralidade para a economia global. Neste sentido, elabore-se uma receita a ser seguida pelos administradores públicos e que contém os ingredientes necessários para a atração de novas empresas e investimentos para os seus municípios. A plena realização deste objetivo estaria circunscrita, ainda, a um questionamento a respeito da permanência da população de menor renda na região central. Todo este processo pode ser compreendido como uma estratégia que, mediante a privatização da esfera pública (do espaço, do poder e dos recursos públicos), procura criar as condições satisfatórias para a reprodução e ampliação do capital no Centro da cidade.

Tal estratégia, no caso paulistano, tem como referência os processos levados a cabo em Barcelona, onde, a partir dos planos estratégicos traçados pelos urbanistas catalães, foram realizadas a conversão de áreas degradas ou subutilizadas da cidade em novas frentes de expansão do capital imobiliário, turístico, etc. Estas intervenções 
estavam circunscritas a um projeto de transformação e adaptação de Barcelona para receber os jogos Olímpicos de 1992.

A experiência de Barcelona passou a ser considerada em todo o mundo como a estratégia mais eficaz para vender a cidade aos empreendedores e investidores transnacionais. Tal "conhecimento" passa a ser, literalmente, comercializado para as demais cidades do mundo, a partir das atividades de consultoria prestadas pelos seus urbanistas - dentre os quais o mais reconhecido é Jordi Borja - às administrações públicas municipais. Conforme analisa Vainer, "talvez esta seja, hoje, uma das idéias mais populares entre os neoplanejadores urbanos: a cidade é uma mercadoria a ser vendida, num mercado extremamente competitivo, em que outras cidades também estão à venda" (VAINER et alii, 2000, p. 78).

Se há décadas atrás era considerada remota a possibilidade de transformar o Centro Histórico e adaptá-lo às necessidades de produção que já estavam manifestadas pelos agentes hegemônicos; os fatos recentes parecem contrariar esta constatação. Temse como exemplo, as políticas do tipo arrasa-quarteirão levadas a cabo pelo poder público em uma região específica do bairro da Santa Ifigênia (Distrito República), pejorativamente denominada por Cracolândia. Estas políticas irão resultar na desapropriação de 164 mil m², que deverão ser reaproveitados para a construção de um pólo tecnológico e novos empreendimentos residenciais, de comércio e serviços, após a demolição das antigas construções e a extinção dos usos até então existentes.

Embora o discurso procure enunciar que a modernização atinge uma área antes caracterizada pelo caos, ele não deixa claro quais são as premissas para a realização deste intento, sejam elas: a venda, em pedaços, da cidade; a apropriação privada de um bem público; a intensificação da segregação sócio-espacial das classes populares, etc.

Nas análises subseqüentes serão retomadas, com maior especificidade, parte das discussões até aqui aventadas. 


\subsection{Dinâmicas recentes do Centro Histórico de São Paulo}

Se as análises até aqui desenvolvidas buscaram dar conta da contextualização da Revalorização do Centro Histórico de São Paulo, pôr em evidência as suas premissas e iluminar alguns dos discursos que permeiam este processo, considera-se necessário complementar essa investigação com o apontamento e análise de dados quantitativos que permitam elaborar um perfil social-econômico da região em questão, bem como, apresentar informações que possibilitem entrever o seu (recente) dinamismo imobiliário, como forma de estabelecer outra aproximação com o objetivo que circunscreve esta pesquisa, ou seja, dimensionar o impacto do processo de revalorização da região central sobre o problema da habitação.

As informações até aqui levantadas dão subsídios à constatação de uma intensa evasão populacional do Centro Histórico de São Paulo entre os anos de 1991 e 2000. Nesse contexto, a região central paulistana ${ }^{44}$ perdeu um em cada cinco moradores que lá habitavam, o que representa $19,7 \%$ de sua população. Como se pode observar na TABELA 1, houve no período de 1991 a 2000 uma representativa diminuição da população residente nos distritos Sé e República, apresentando, respectivamente, taxas de decréscimo populacional da ordem de $26,0 \%$ e $17,8 \%$, o que representaria em números absolutos 17.418 habitantes, o que equivale à população de uma cidade de pequeno porte.

Em outra comparação, poderíamos sugerir que, enquanto os distritos Sé e República demonstraram elevado decréscimo de população, o município de São Paulo apresentou um crescimento populacional de 7,8\%. Parte deste incremento no município pode estar associado diretamente ao crescimento populacional dos distritos localizados na periferia de São Paulo, tais como: Anhangüera (+210,3\%), São Miguel Paulista $(+120,8 \%)$, e Parelheiros (+84,3\%).

Se o Centro Histórico diminui em termos de população e a periferia vive, por sua vez, uma situação totalmente oposta, poderia se deduzir que o esvaziamento de um resulta

\footnotetext{
${ }^{44}$ Considera-se como região central os distritos República e Sé (o chamado Centro Histórico), e os distritos Bela Vista, Bom Retiro, Cambuci, Consolação, Liberdade e Santa Cecília (que a partir de 2002 passaram a compor a Subprefeitura Sé do Município de São Paulo).
} 
TABELA 1: População residente e crescimento populacional do Município de São Paulo e dos seus distritos - 1991-2000

\begin{tabular}{|c|c|c|c|c|}
\hline \multirow{2}{*}{ Distritos } & \multicolumn{2}{|l|}{ População } & \multirow{2}{*}{$\begin{array}{c}\text { Crescimento } \\
\text { pop. } 1991-2000\end{array}$} & \multirow{2}{*}{$\begin{array}{c}\text { Crescimento pop. } \\
1991-2000(\%)\end{array}$} \\
\hline & 1991 & 2000 & & \\
\hline Mun. de São Paulo & 9.646 .185 & 10.405 .867 & 759682,00 & 7,88 \\
\hline Água Rasa & 95.099 & 85.824 & $-9275,00$ & $-9,75$ \\
\hline Alto de Pinheiros & 50.351 & 44.417 & $-5934,00$ & $-11,79$ \\
\hline Anhanguera & 12.408 & 38.502 & 26094,00 & 210,30 \\
\hline Aricanduva & 96.512 & 94.758 & $-1754,00$ & $-1,82$ \\
\hline Artur Alvim & 118.531 & 110.789 & $-7742,00$ & $-6,53$ \\
\hline Barra Funda & 15.977 & 12.936 & $-3041,00$ & $-19,03$ \\
\hline Bela Vista & 71.825 & 63.143 & $-8682,00$ & $-12,09$ \\
\hline Belém & 49.697 & 38.268 & $-11429,00$ & $-23,00$ \\
\hline Bom Retiro & 36.136 & 26.569 & $-9567,00$ & $-26,47$ \\
\hline Brás & 33.536 & 24.505 & $-9031,00$ & $-26,93$ \\
\hline Brasilândia & 201.591 & 246.932 & 45341,00 & 22,49 \\
\hline Butantã & 58.019 & 52.532 & $-5487,00$ & $-9,46$ \\
\hline Cachoeirinha & 125.852 & 147.549 & 21697,00 & 17,24 \\
\hline Cambuci & 37.069 & 28.620 & $-8449,00$ & $-22,79$ \\
\hline Campo Belo & 77.952 & 66.314 & $-11638,00$ & $-14,93$ \\
\hline Campo Grande & 82.052 & 91.206 & 9154,00 & 11,16 \\
\hline Campo Limpo & 159.471 & 190.840 & 31369,00 & 19,67 \\
\hline Cangaíba & 115.070 & 136.088 & 21018,00 & 18,27 \\
\hline Capão Redondo & 193.497 & 242.368 & 48871,00 & 25,26 \\
\hline Carrão & 87.336 & 77.561 & $-9775,00$ & $-11,19$ \\
\hline Casa Verde & 96.396 & 83.615 & $-12781,00$ & $-13,26$ \\
\hline Cidade Ademar & 230.794 & 243.273 & 12479,00 & 5,41 \\
\hline Cidade Dutra & 168.821 & 190.079 & 21258,00 & 12,59 \\
\hline Cidade Líder & 97.370 & 116.170 & 18800,00 & 19,31 \\
\hline Cidade Tiradentes & 96.281 & 190.555 & 94274,00 & 97,92 \\
\hline Consolação & 66.590 & 54.301 & $-12289,00$ & $-18,45$ \\
\hline Cursino & 110.435 & 101.929 & $-8506,00$ & $-7,70$ \\
\hline Ermelino Matarazzo & 95.609 & 106.731 & 11122,00 & 11,63 \\
\hline Freguesia do Ó & 152.672 & 144.468 & $-8204,00$ & $-5,37$ \\
\hline Grajaú & 193.754 & 331.971 & 138217,00 & 71,34 \\
\hline Guaianases & 81.373 & 98.137 & 16764,00 & 20,60 \\
\hline Iguatemi & 59.820 & 101.688 & 41868,00 & 69,99 \\
\hline Ipiranga & 101.533 & 98.235 & $-3298,00$ & $-3,25$ \\
\hline Itaim Bibi & 107.497 & 81.331 & $-26166,00$ & $-24,34$ \\
\hline Itaim Paulista & 163.269 & 212.677 & 49408,00 & 30,26 \\
\hline Itaquera & 175.366 & 201.178 & 25812,00 & 14,72 \\
\hline Jabaquara & 214.350 & 214.199 & $-151,00$ & $-0,07$ \\
\hline Jaçanã & 86.830 & 91.649 & 4819,00 & 5,55 \\
\hline Jaguara & 29.798 & 25.701 & $-4097,00$ & $-13,75$ \\
\hline Jaguaré & 44.361 & 42.410 & $-1951,00$ & $-4,40$ \\
\hline Jaraguá & 93.185 & 145.525 & 52340,00 & 56,17 \\
\hline Jardim Ângela & 178.373 & 243.845 & 65472,00 & 36,71 \\
\hline Jardim Helena & 118.381 & 138.585 & 20204,00 & 17,07 \\
\hline Jardim Paulista & 103.138 & 82.657 & $-20481,00$ & $-19,86$ \\
\hline Jardim São Luiz & 204.284 & 236.967 & 32683,00 & 16,00 \\
\hline José Bonifácio & 103.712 & 107.053 & 3341,00 & 3,22 \\
\hline Lajeado & 112.807 & 157.835 & 45028,00 & 39,92 \\
\hline Lapa & 70.319 & 60.070 & $-10249,00$ & $-14,58$ \\
\hline Liberdade & 76.245 & 61.850 & $-14395,00$ & $-18,88$ \\
\hline Limão & 90.422 & 82.016 & $-8406,00$ & $-9,30$ \\
\hline Mandaqui & 104.022 & 103.061 & $-961,00$ & $-0,92$ \\
\hline
\end{tabular}




\begin{tabular}{|c|c|c|c|c|}
\hline \multirow{2}{*}{ Distritos } & \multicolumn{2}{|l|}{ População } & \multirow{2}{*}{$\begin{array}{c}\text { Crescimento } \\
\text { pop. } 1991-2000\end{array}$} & \multirow{2}{*}{\begin{tabular}{|c|} 
Crescimento pop. \\
$1991-2000(\%)$ \\
\end{tabular}} \\
\hline & 1991 & 2000 & & \\
\hline Marsilac & 5.992 & 8.416 & 2424,00 & 40,45 \\
\hline Moema & 77.340 & 69.489 & $-7851,00$ & $-10,15$ \\
\hline Moóca & 71.999 & 63.211 & $-8788,00$ & $-12,21$ \\
\hline Morumbi & 40.031 & 33.891 & $-6140,00$ & $-15,34$ \\
\hline Parelheiros & 55.594 & 102.493 & 46899,00 & 84,36 \\
\hline Pari & 21.299 & 14.521 & $-6778,00$ & $-31,82$ \\
\hline Parque do Carmo & 54.743 & 63.923 & 9180,00 & 16,77 \\
\hline Pedreira & 86.001 & 127.478 & 41477,00 & 48,23 \\
\hline Penha & 133.006 & 123.166 & $-9840,00$ & $-7,40$ \\
\hline Perdizes & 108.840 & 102.160 & $-6680,00$ & $-6,14$ \\
\hline Perus & 46.301 & 70.715 & 24414,00 & 52,73 \\
\hline Pinheiros & 78.644 & 62.393 & $-16251,00$ & $-20,66$ \\
\hline Pirituba & 152.305 & 161.732 & 9427,00 & 6,19 \\
\hline Ponte Rasa & 102.702 & 97.584 & $-5118,00$ & $-4,98$ \\
\hline Raposo Tavares & 82.890 & 90.580 & 7690,00 & 9,28 \\
\hline República & 57.797 & 47.459 & $-10338,00$ & $-17,89$ \\
\hline Rio Pequeno & 102.791 & 111.691 & 8900,00 & 8,66 \\
\hline S.Miguel Paulista & 102.964 & 227.423 & 124459,00 & 120,88 \\
\hline Sacomã & 211.200 & 71.111 & $-140089,00$ & $-66,33$ \\
\hline Santa Cecília & 85.829 & 125.036 & 39207,00 & 45,68 \\
\hline Santana & 137.679 & 59.758 & $-77921,00$ & $-56,60$ \\
\hline Santo Amaro & 75.556 & 82.824 & 7268,00 & 9,62 \\
\hline São Domingos & 70.386 & 139.086 & 68700,00 & 97,60 \\
\hline São Lucas & 152.036 & 154.785 & 2749,00 & 1,81 \\
\hline São Mateus & 150.764 & 97.326 & $-53438,00$ & $-35,44$ \\
\hline São Rafael & 89.862 & 125.132 & 35270,00 & 39,25 \\
\hline Sapopemba & 257.617 & 281.985 & 24368,00 & 9,46 \\
\hline Saúde & 126.596 & 117.910 & $-8686,00$ & $-6,86$ \\
\hline Sé & 27.186 & 20.106 & $-7080,00$ & $-26,04$ \\
\hline Socorro & 43.194 & 39.017 & $-4177,00$ & $-9,67$ \\
\hline Tatuapé & 81.840 & 79.105 & $-2735,00$ & $-3,34$ \\
\hline Tremembé & 125.075 & 163.783 & 38708,00 & 30,95 \\
\hline Tucuruvi & 111.884 & 99.173 & $-12711,00$ & $-11,36$ \\
\hline Vila Andrade & 42.576 & 75.393 & 32817,00 & 77,08 \\
\hline Vila Curuçá & 124.300 & 146.220 & 21920,00 & 17,63 \\
\hline Vila Formosa & 97.940 & 93.751 & $-4189,00$ & $-4,28$ \\
\hline Vila Guilherme & 61.625 & 49.933 & $-11692,00$ & $-18,97$ \\
\hline Vila Jacuí & 101.236 & 141.630 & 40394,00 & 39,90 \\
\hline Vila Leopoldina & 26.827 & 26.832 & 5,00 & 0,02 \\
\hline Vila Maria & 122.662 & 112.469 & $-10193,00$ & $-8,31$ \\
\hline Vila Mariana & 132.822 & 123.618 & $-9204,00$ & $-6,93$ \\
\hline Vila Matilde & 109.023 & 102.254 & $-6769,00$ & $-6,21$ \\
\hline Vila Medeiros & 156.140 & 140.500 & $-15640,00$ & $-10,02$ \\
\hline Vila Prudente & 114.297 & 102.072 & $-12225,00$ & $-10,70$ \\
\hline Vila Sônia & 83.006 & 87.251 & 4245,00 & 5,11 \\
\hline
\end{tabular}


no crescimento do outro. Embora essa dedução possa fazer algum sentido, esta pesquisa não dispõe dos elementos necessários para certificá-la. Contudo, não se pode descartar que a iminência da revalorização da região central pode induzir, pela especulação imobiliária e pela possível elevação dos aluguéis, a uma mobilidade dos mais pobres para áreas onde os custos com moradia venham a ser mais baixos - estas áreas geralmente estão situadas na periferia da cidade.

Deve-se mencionar, inclusive, que o baixo custo do preço do solo na periferia, constitui um dos elementos pelo qual se tem estimulado há décadas a sua ocupação populacional. Ao verificar a TABELA 2, é possível constatar que desde os anos 60 o Estado tem adotado uma política de habitação baseada na construção de conjuntos habitacionais populares em áreas periféricas da cidade. Como exemplo, pode-se observar que a região Leste de São Paulo - que constitui uma das áreas de maior concentração de pobreza da cidade - reúne $61,5 \%$ do total destes conjuntos habitacionais.

Em situação oposta àquela apresentada pela região Leste, está o Centro Histórico de São Paulo. Esta região concentra somente 2,5\% dos conjuntos populares do município. Este número pode sugerir que uma mesma política que incentivou a ocupação da periferia pelas classes populares - direcionando-as para áreas carentes em serviços públicos e infra-estrutura urbana, geralmente, distantes da região central pretendeu, por outro lado, desestimular a habitação popular no Centro da cidade. O que pode sugerir que a estratégia do poder público, em voga durante décadas, tinha como orientação a produção da cidade segundo uma segregação sócio-espacial da sua população.

\begin{tabular}{|l|r|r|r|r|r|r|r|r|}
\hline \multicolumn{7}{|c|}{ TABELA 2: Localização dos conjuntos populares e unidades concluídas até 1997, segundo órgãos } \\
promotores e localização
\end{tabular}


Esta questão se torna ainda mais problemática se esta última informação for relacionada com os dados presentes na TABELA 3, a respeito dos domicílios particulares vagos de São Paulo. Neste caso, pode-se observar a existência, nos distritos centrais, de um total de 45.464 domicílios vagos, sendo que 22\% (10.062) deles estão distribuídos entre os distritos República e Sé, que compõem o Centro Histórico da cidade. Deste modo, enquanto grande parte da população pobre é estrategicamente levada à periferia, a classe de maior poder renda, proprietária dos domicílios deixados à ociosidade, aguardam por um novo momento de valorização do seu bem. Segundo Bomfim, com a permanência de domicílios vazios no Centro "os proprietários aguardam a concretização de uma política efetiva de recuperação da área central [...]. A partir dela e das direções resultantes, os imóveis vazios serão orientados para determinados usos. É a garantia da efetivação de lucros e rendas esperadas” (BOMFIM, 2004, p. 100).

\begin{tabular}{|l|r|r|r|}
\hline \multicolumn{4}{|c|}{ TABELA 3: Domicílios particulares vagos nos distritos centrais de São Paulo - 2000 } \\
\hline Distritos & \multicolumn{1}{|c|}{ Total de recenseados } & Domicilios vagos & Domicílios vagos/total \\
\hline Bela Vista & 33.848 & 5.479 & $16,2 \%$ \\
\hline Bom Retiro & 10.807 & 1.821 & $16,9 \%$ \\
\hline Cambuci & 11.370 & 1.910 & $16,8 \%$ \\
\hline Consolação & 29.577 & 3.694 & $12,5 \%$ \\
\hline Liberdade & 29.392 & 5.283 & $\mathbf{2 2 , 7 \%}$ \\
\hline República & $\mathbf{3 0 . 8 4 9}$ & $\mathbf{7 . 0 0 7}$ & $17,5 \%$ \\
\hline Santa Cecília & 36.171 & 6.343 & $\mathbf{2 6 , 8 \%}$ \\
\hline Sé & $\mathbf{1 1 . 4 1 0}$ & $\mathbf{3 . 0 5 5}$ & $11,8 \%$ \\
\hline Município de São Paulo & 3.554 .820 & 420.327 & \\
\hline Fonte: IBGE, Censo 2000 apud SILVA, H.,2000, p. 8 \\
\hline
\end{tabular}

Ao mesmo tempo em que o Centro Histórico constitui uma das maiores áreas de concentração de domicílios vagos da cidade é nesta região que podem ser encontrados, também, elevados índices de concentração de cortiços. Embora ainda não haja um levantamento preciso a respeito do número deste tipo de habitação em São Paulo, baseado em uma pesquisa realizada pela FIPE (Fundação Instituto de Pesquisas Econômicas) em 1993, Silva H. (2000) indica que cerca de $20 \%$ da população encortiçada se encontra na Administração Regional da Sé ${ }^{35}$ (composta pelos distritos Bom Retiro, Pari, Brás, Cambuci, Liberdade, República, Sé, Bela Vista, Consolação e Santa Cecília), o que equivaleria a $25 \%$ do total da população dessa região.

35 Em 2002, por meio de um projeto de lei que implantou as Subprefeituras em São Paulo, a Administração Regional da Sé, passou a se chamar Subprefeitura Sé, porém os distritos Pari e Brás deixaram de integrá-la. 
Do mesmo modo, podemos fazer referência a outra pesquisa da FIPE que, encomendada pela Prefeitura de São Paulo/Subprefeitura Sé, traz informações a respeito do número de moradores de rua existentes na cidade, no ano de 2000. Conforme se pode observar na TABELA 4, somente os distritos Sé e República reúnem 18,5\% do total da população em situação de rua de todo o Município.

\begin{tabular}{|l|c|c|}
\hline \multicolumn{3}{|c|}{ TABELA 4: Número de moradores de rua do Município de São Paulo, segundo } \\
distritos - 2000
\end{tabular}

Portanto, essas informações são reveladoras de uma situação contrastante e desigual em relação à ocupação, com fins de moradia, do Centro Histórico de São Paulo. Se de um lado as classes mais abastadas buscam, por meio da manutenção de domicílios ociosos, nutrir uma atividade especulativa e de caráter rentista na região central, de outro lado, as classes populares e aquelas marginalizadas, salvo as suas especificidades, procuram formas, mesmo que precárias, de habitar o Centro e estabelecer alguma possibilidade de sobrevivência e de reprodução da sua própria vida.

Os dados a respeito da distribuição dos domicílios, por faixa de renda segundo os distritos do município de São Paulo para o ano de 2000, TABELA 5, sugerem que o Centro Histórico ainda se constitui como uma área marcada por uma mistura de classes sociais. Embora nos distritos República e Sé predominem os domicílios com renda de 5 a menos de 10 salários mínimos, (31,1\% na República e $31,8 \%$ na Sé) são significativas, nestas duas áreas, a proporção de domicílios que se enquadram em faixas de renda que podem ser consideradas polares: de 2 a menos de 5 salários mínimos (16,6\% República e $25 \%$ na Sé) e de 10 a menos de 15 salários mínimos ( 15,6\% República, e 14,5\% Sé). 


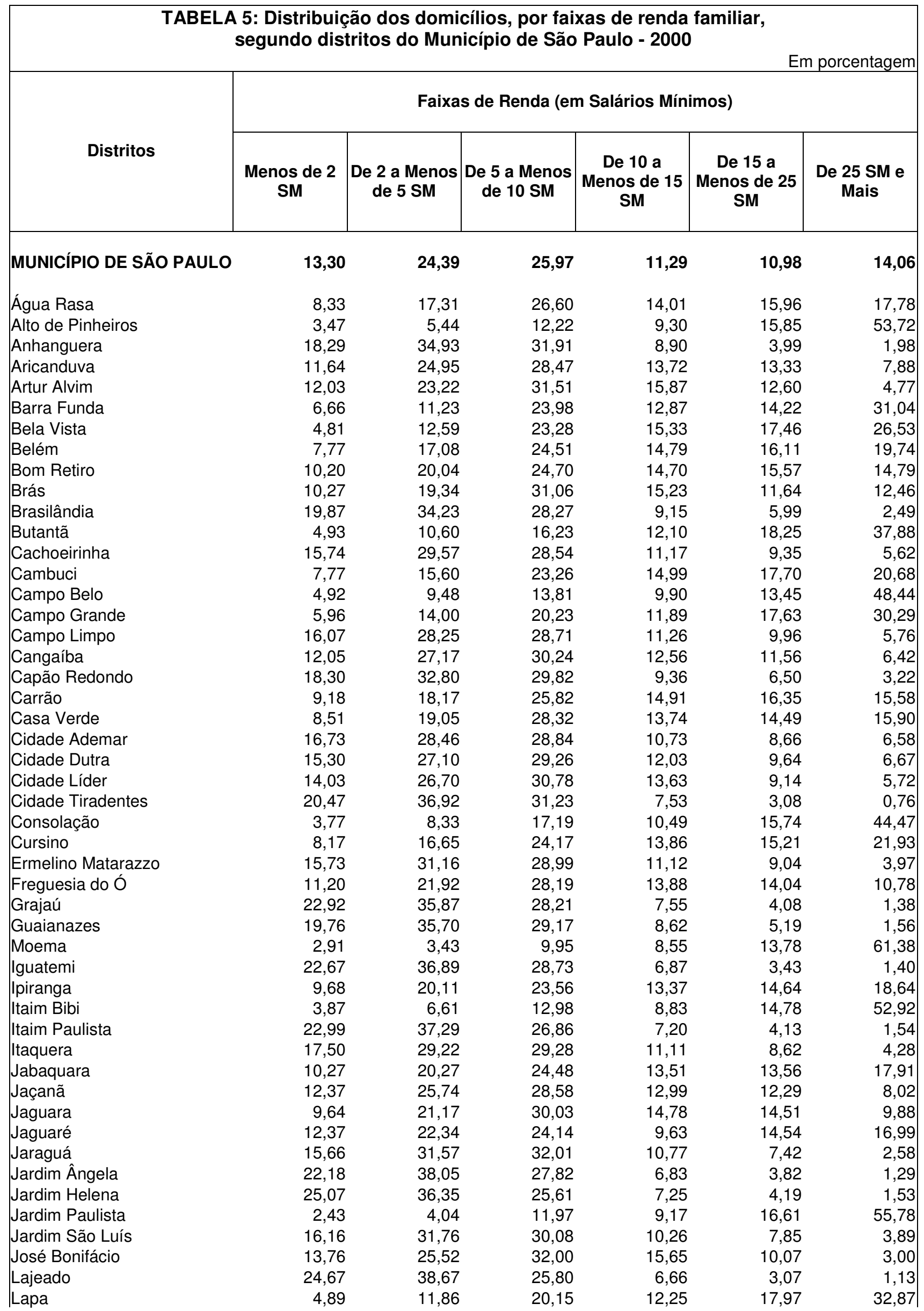




\begin{tabular}{|c|c|c|c|c|c|c|}
\hline \multicolumn{7}{|c|}{$\begin{array}{l}\text { TABELA 5: Distribuição dos domicílios, por faixas de renda familiar, } \\
\text { segundo distritos do Município de São Paulo - } 2000\end{array}$} \\
\hline & & & & & En & porcentagem \\
\hline \multirow[b]{2}{*}{ Distritos } & \multicolumn{6}{|c|}{ Faixas de Renda (em Salários Mínimos) } \\
\hline & $\begin{array}{l}\text { Menos de } 2 \\
\text { SM }\end{array}$ & $\begin{array}{l}\text { De } 2 \text { a Menos } \\
\text { de } 5 \text { SM }\end{array}$ & $\begin{array}{l}\text { De } 5 \text { a Menos } \\
\text { de } 10 \mathrm{SM}\end{array}$ & $\begin{array}{c}\text { De } 10 \text { a } \\
\text { Menos de } 15 \\
\text { SM }\end{array}$ & $\begin{array}{c}\text { De } 15 \text { a } \\
\text { Menos de } 25 \\
\text { SM }\end{array}$ & $\begin{array}{l}\text { De } 25 \text { SM e } \\
\text { Mais }\end{array}$ \\
\hline Liberdade & 6,47 & 13,96 & \multicolumn{2}{|r|}{11,52} & 16,90 & 29,59 \\
\hline Limão & 11,30 & 24,80 & \multicolumn{2}{|r|}{14,25} & 13,54 & 10,62 \\
\hline Mandaqui & 6,73 & 15,36 & \multicolumn{2}{|r|}{15,25} & 17,32 & 20,70 \\
\hline Marsilac & 44,10 & 31,22 & \multicolumn{2}{|r|}{4,31} & 0,19 & 0,71 \\
\hline Moóca & 6,70 & 13,11 & 21,07 & 12,54 & 18,11 & 28,48 \\
\hline Morumbi & 4,00 & 9,05 & 10,76 & 5,67 & 9,95 & 60,58 \\
\hline Parelheiros & 26,06 & 38,16 & 25,79 & 6,15 & 2,83 & 1,01 \\
\hline Pari & 10,84 & 20,53 & 24,98 & 14,91 & 14,95 & 13,80 \\
\hline Parque do Carmo & 16,08 & 29,07 & 30,80 & 11,41 & 8,25 & 4,39 \\
\hline Pedreira & 21,24 & 32,70 & 28,57 & 8,86 & 5,60 & 3,03 \\
\hline Penha & 11,25 & 21,04 & 26,39 & 14,51 & 13,76 & 13,05 \\
\hline Perdizes & 2,70 & 5,45 & 12,84 & 10,72 & 17,47 & 50,83 \\
\hline Perus & 18,27 & 35,47 & 29,33 & 9,61 & 4,94 & 2,39 \\
\hline Pinheiros & 3,77 & 5,98 & 14,34 & 9,60 & 16,53 & 49,79 \\
\hline Pirituba & 11,94 & 23,63 & 27,39 & 13,39 & 13,55 & 10,09 \\
\hline Ponte Rasa & 11,81 & 23,99 & 30,66 & 13,89 & 12,35 & 7,30 \\
\hline Raposo Tavares & 12,73 & 27,95 & 29,05 & 12,50 & 10,54 & 7,24 \\
\hline República & 8,09 & 16,69 & 31,18 & 15,64 & 14,93 & 13,46 \\
\hline Rio Pequeno & 11,80 & 22,00 & 22,77 & 12,38 & 13,08 & 17,96 \\
\hline Sacomã & 12,16 & 23,27 & 28,38 & 12,81 & 12,92 & 10,47 \\
\hline Santa Cecília & 5,53 & 11,60 & 23,33 & 14,45 & 17,95 & 27,14 \\
\hline Santana & 4,90 & 9,79 & 19,97 & 14,06 & 18,15 & 33,13 \\
\hline Santo Amaro & 4,17 & 6,84 & 16,87 & 10,41 & 18,59 & 43,13 \\
\hline Sao Domingos & 9,94 & 23,88 & 26,83 & 12,95 & 12,93 & 13,46 \\
\hline São Lucas & 11,43 & 22,31 & 28,44 & 14,50 & 13,85 & 9,46 \\
\hline São Mateus & 15,19 & 29,02 & 29,37 & 12,68 & 9,81 & 3,93 \\
\hline São Miguel & 17,47 & 30,40 & 28,29 & 10,75 & 8,87 & 4,23 \\
\hline São Rafael & 21,34 & 35,49 & 28,48 & 8,17 & 4,79 & 1,74 \\
\hline Sapopemba & 18,08 & 31,19 & 30,19 & 10,75 & 6,79 & 3,00 \\
\hline Saúde & 3,96 & 9,12 & 17,22 & 10,84 & 18,52 & 40,33 \\
\hline Sé & 11,02 & 25,04 & 31,85 & 14,56 & 10,45 & 7,09 \\
\hline Socorro & 8,65 & 13,72 & 24,01 & 12,82 & 17,58 & 23,22 \\
\hline Tatuapé & 5,92 & 11,73 & 18,17 & 12,14 & 18,99 & 33,05 \\
\hline Tremembé & 13,14 & 27,78 & 28,30 & 11,43 & 9,74 & 9,62 \\
\hline Tucuruvi & 7,27 & 16,38 & 24,87 & 15,11 & 18,15 & 18,20 \\
\hline Vila Andrade & 14,15 & 25,13 & 17,41 & 5,50 & 6,37 & 31,44 \\
\hline Vila Curuça & 22,61 & 34,37 & 27,32 & 8,68 & 4,74 & 2,28 \\
\hline Vila Formosa & 8,10 & 20,08 & 28,69 & 13,91 & 13,08 & 16,14 \\
\hline Vila Guilherme & 8,79 & 18,24 & 27,99 & 15,52 & 14,95 & 14,51 \\
\hline Vila Jacuí & 19,02 & 34,65 & 28,16 & 9,23 & 6,14 & 2,80 \\
\hline Vila Leopoldina & 5,15 & 19,06 & 16,64 & 9,59 & 15,95 & 33,61 \\
\hline Vila Maria & 12,26 & 27,16 & 29,32 & 12,11 & 10,93 & 8,22 \\
\hline Vila Mariana & 2,87 & 7,03 & 13,69 & 9,90 & 17,47 & 49,05 \\
\hline Vila Matilde & 10,26 & 22,29 & 28,47 & 14,83 & 14,01 & 10,16 \\
\hline Vila Medeiros & 12,32 & 24,21 & 31,25 & 13,80 & 11,97 & 6,45 \\
\hline Vila Prudente & 10,43 & 21,42 & 27,28 & 12,52 & 13,92 & 14,43 \\
\hline Vila Sônia & 9,58 & 16,05 & 20,05 & 11,28 & 13,96 & 29,07 \\
\hline $\begin{array}{l}\text { Fonte: IBGE; Funda } \\
\text { Nota: Excluindo-se c } \\
\text { Salário mínimo de re }\end{array}$ & écie & do tipo coleti & L & & & \\
\hline
\end{tabular}


Todavia, deve-se questionar a respeito das possibilidades futuras de manutenção desse quadro de mistura social na região central, principalmente, no que diz respeito à permanência, no Centro Histórico de São Paulo, da população de baixa renda. Isto porque, no processo de revalorização desta centralidade, a definição de uma política de habitação para este espaço não pressupõe, necessariamente, o desenvolvimento de medidas que controlem a valorização da região e a conseqüente remoção da população pobre para outras áreas.

Como será visto adiante, as diferentes gestões municipais que estiveram à frente da Prefeitura de São Paulo, entre os anos de 1991 e 2006, associaram à revalorização do Centro Histórico estratégias visando reforçar a sua função habitacional. Entretanto, as políticas definidas pouco privilegiaram as demandas das classes populares por habitação na região central. Por outro lado, um novo dinamismo do mercado imobiliário privado no Centro de São Paulo já pode ser constatado. No período de 1999 a 2004, conforme registrou o Datafolha, o lançamento de imóveis na região central ${ }^{36}$ aumentou em $143 \%$ (FOLHA DE S. PAULO, 2004a).

Embora, em números absolutos, o Centro de São Paulo ainda seja a região com o menor número de lançamentos imobiliários ${ }^{37}$, este fato parece denotar uma nova condição de ocupação da região central paulistana, como resultado do seu processo de revalorização e da possível atração de um novo contingente populacional, cuja condição social e econômica deve diferir, em muito, das famílias pobres que demandam por habitação no Centro da cidade. Contudo, esses pressupostos parecem já se confirmar, pois os novos apartamentos em construção no Centro de São Paulo ${ }^{38}$ - em um total de 1.326 unidades habitacionais - são destinados a famílias com renda mensal entre 5 e 10 salários mínimos. Como é possível observar na FIGURA 3, três dos seis novos empreendimentos imobiliários em execução na região central estão concentrados no distrito República, e o preço desses imóveis varia entre 50 mil reais e 146 mil reais (FOLHA DE S. PAULO, 2007). Deste modo, em função do custo elevado que podem representar para a população de baixa renda, a aquisição dessas propriedades deve, certamente, estar destina à classe média paulistana.

\footnotetext{
36 Não há a especificação dos distritos que compõe esta região, podendo ser possível que os valores levantados se refiram para os demais distritos do Centro, além da República e da Sé.

${ }^{37}$ Os lançamentos imobiliários em São Paulo até 2004 apresentavam-se na seguinte forma: Zona Sul 474 prédios novos; Zona Oeste - 353; Zona Leste - 213; Zona Norte - 109; e Centro - 59.

${ }^{38}$ Com previsão de lançamento para 2008.
} 
Figura 3: Novos prédios no Centro de São Paulo

\section{NOVOS PRÉDIOS NO CENTRO DE SP}

Regĩão terá seis novos condominios em dois anos

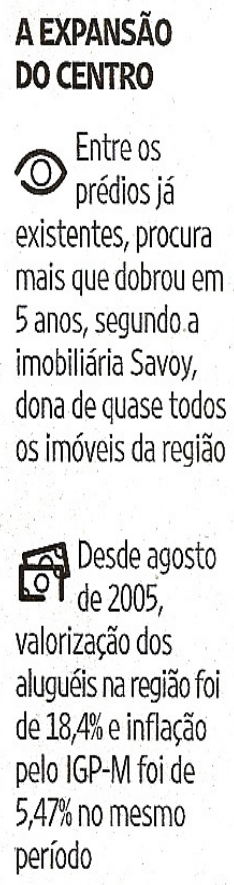

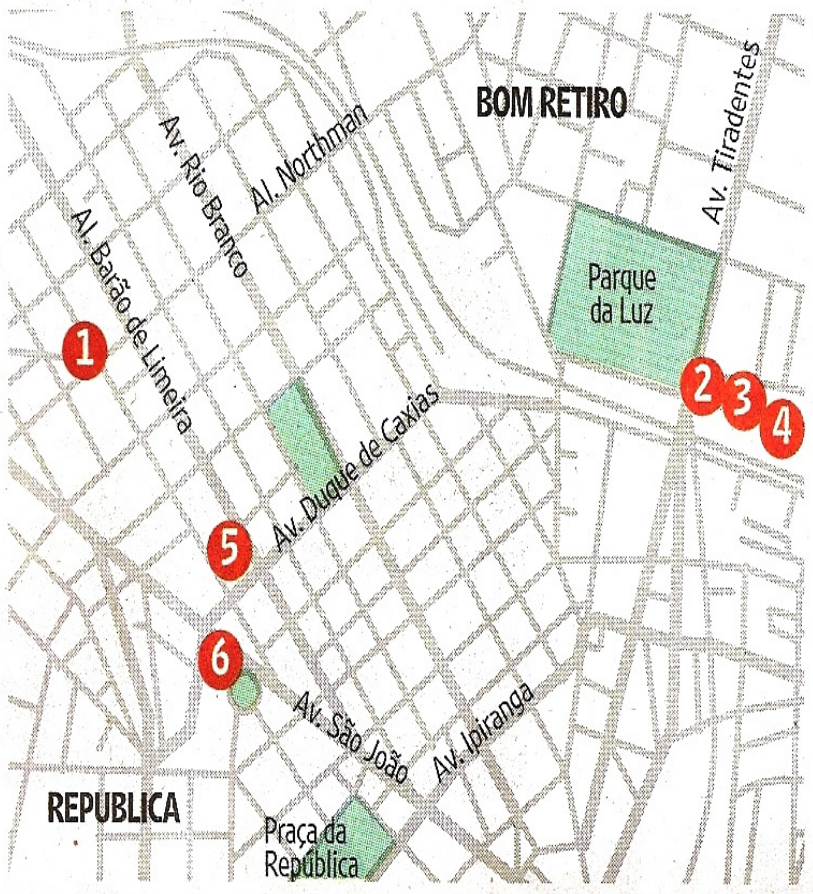

OS EDIFÍCIOS

1 Esquina da alameda Northman com a rua Adolfo Gordo (316 apartamentos) R\$72,9 mil a R\$77,9 mil

2 Rua 25 de Janeiro, 102 (103 apartamentos) $R \$ 50$ mil á $R \$ 65$ mil

3 Rua 25 de Janeiro, 151 (300 apartamentos) $R \$ 43$ mil a $R \$ 51,5$ mil

(4) Rua 25 de Janeiro, 180 (270 apartamentos) $R \$ 102 \mathrm{mil}$

5 Av. Duque de Caxias, 159 (240 apartamentos) $R \$ 113,8$ mil a $\$ 146$ mil

6 Av. São João, 300 (26 apartamentos)

Prédios do arquiteto Ramos de Azzevedo (18511928). Foram restaurados para virar um condomínio residencial $R \$ 50$ mil a $R \$ 100$ mil

Fonte: (FOLHA DE SÃO PAULO, 2007) 
Dentre os novos lançamentos, inclui-se a transformação de dois antigos hotéis em um novo condomínio residencial. Esses dois edifícios estão localizados na Avenida São João e foram construídos entre os anos de 1914 e 1918, pelo renomado arquiteto Ramos de Azevedo (1851-1928). Devido ao seu valor histórico e arquitetônico recentemente foram tombados pelo patrimônio histórico do Estado e do Município de São Paulo ${ }^{39}$. Antes de se tornarem alvo do mercado imobiliário, os hotéis abrigavam aposentados e moradores de baixa renda, que tiveram que desocupá-lo para que fosse dado início à sua reforma (FOLHA DE S. PAULO, 2007). Deste modo, evidencia-se que a "chegada" da população de maior poder aquisitivo ao Centro de São Paulo, não se realiza sem causar prejuízos à permanência da população mais pobre.

A valorização imobiliária do Centro de São Paulo parece ser um dado concreto nos dias de hoje, tal como veiculado pelo jornal Folha de S. Paulo "Novos prédios dão fôlego ao centro velho" (FOLHA DE S. PAULO, 2007, p. C1-C3). Esta valorização imobiliária pode estar expressa, de um lado, no aumento do valor do aluguel na região, que desde 2005 foi elevado em 18\%, de acordo com a medição realizada pelo Secovi (Sindicado da Habitação); e de outro, na procura por imóveis nesta mesma região, que nos últimos cinco anos dobrou em relação aos períodos anteriores (FOLHA DE S. PAULO, 2007).

Esses dados tendem a contrastar com as informações que, publicadas em 2002, procuravam atribuir aos sem-teto a responsabilidade por promover uma suposta valorização da região central, a exemplo da manchete "Sem-teto lideram reocupação do centro", também, veiculada pela Folha de S. Paulo (FOLHA DE S. PAULO, 2002, p. C1). O mote para essas constatações tinha como referência a compra e reforma de edifícios vazios lideradas/negociadas pelos movimentos de moradia, visando à produção de habitação popular no Centro da cidade, com recursos dos programas da Caixa Econômica Federal, da prefeitura e do governo do Estado.

Embora uma informação não anule a outra, pode-se pressupor que a mudança deste cenário entre os anos de 2002 e 2007, justifica-se em função dos pressupostos ou ideais para a revalorização do Centro Histórico de São Paulo (com ênfase no reforço habitacional dessa região) defendidos pela gestão municipal que administrou São Paulo

\footnotetext{
39 Estes edifícios foram tombados pelo Conselho de Defesa do Patrimônio Histórico, Arqueológico, Artístico e Turístico (Condephaat), - órgão do Estado de São Paulo; e pelo Conselho de Proteção do Patrimônio Histórico, Cultural e Ambiental da Cidade de São Paulo (Concresp) - órgão da Prefeitura Municipal de São Paulo.
} 
entre os anos de 2001 e 2004, em contraste com as propostas da atual gestão do município, que procura conciliar, em maior demasia, os seus projetos com os interesses dos agentes privados (dentre eles, o setor imobiliário), ao mesmo tempo em que busca impor limites à ocupação do Centro Histórico pelas classes populares.

\subsection{Revalorização do Centro Histórico de São Paulo: gentrificação em curso ? $^{40}$}

Traçados alguns elementos que permitem contextualizar a revalorização do Centro Histórico de São Paulo, tendo identificado parte dos discursos e conflitos que se manifestam no bojo deste processo, e realizada uma delimitação do quadro social, econômico e do recente dinamismo imobiliário desta região; seria possível afirmar pela existência de um processo de gentrificação ${ }^{41}$ ?

A análise e sistematização de informações feitas por Rigol (2005) permitem entrever que em diversas cidades do mundo - dentre as quais o Brasil ${ }^{42}$ - foram observados processos de mudanças físicas e sociais ligadas à gentrificação - salvas as suas especificidades sociais, culturais e econômicas - que revelariam como elemento comum:

[...] a população com poucos recursos econômicos e culturais é expulsa e substituída por uma nova população com maiores recursos econômicos e culturais; as velhas residências degradadas são reabilitadas ou renovadas; novos empreendimentos comerciais, restaurantes, galerias de arte e bares se estabelecem nos espaços antes ocupados pelo comércio tradicional que permitia a subsistência dos antigos moradores; o espaço público é renovado e protegido daquelas atividades indesejáveis [...] (RIGOL, 2005, p. 99-100).

No caso de São Paulo, a resposta mais plausível para o questionamento acima levantado é a de que há em curso uma tendência de gentrificação do espaço urbano, tornada evidente a partir das estratégias para revalorização do seu Centro Histórico. Esta

\footnotetext{
${ }^{40}$ Nesta pesquisa, procura-se apenas delinear uma aproximação em relação e este tema.

${ }^{41}$ Este conceito foi cunhado por Ruth Glass para se referir à mudança social ocorrida nos anos $60 \mathrm{em}$ bairros operários londrinos, quando os antigos moradores foram expulsos dessas áreas para dar lugar à sua ocupação pela população de classe média (BIDOU-ZACHARIASEN, 2006; RIGOL, 2005). Hoje, Neil Smith é um dos principais teóricos da gentrification, para ele este movimento de retorno das classes médias e médias altas ao Centro das grandes cidades (a exemplo de Nova Iorque) implica sempre no deslocamento das classes populares. Segundo Smith: "Não é a população em geral que deve ser 'reconduzida ao centro' [...] este chamado de retorno às áreas centrais é sempre um chamado 'interessado' para que as classes médias e médias altas brancas recuperem o controle das políticas econômicas e culturais, assim como do espaço nas grandes cidades” (SMITH, 2006).

${ }^{42}$ Não há no texto uma indicação a respeito sobre o lugar no Brasil ao qual o autor está se referindo.
} 
afirmação tem procedência a partir da constatação que, associada a uma política de intervenção para transformação do espaço na região central, são delimitados planos e ações que sinalizam uma mudança na sua composição social. Esta mudança se evidencia pelo estímulo do poder público - com especial ênfase para a atual gestão municipal $^{43}$ - a uma nova ocupação desta área, que se efetivaria por meio da remoção da população de baixa renda e a atração das classes médias ou da população de maior poder aquisitivo ao Centro da cidade.

A tendência de gentrificação em São Paulo parece se confirmar, ainda, como resultado da atual valorização imobiliária desta região, que possivelmente fará com que as classes populares saiam (ou sejam expulsas) do Centro, em função dos custos elevados para permanecer morando lá. Simultaneamente a esse processo, já é possível observar a atuação do mercado imobiliário preparando o "retorno" das classes médias, por meio do lançamento de novos empreendimentos habitacionais. Deve-se ressaltar que os novos projetos imobiliários em execução no Centro cidade seguem na esteira dos investimentos realizados pelo poder público para reordenação e refuncionalização desse espaço.

Entretanto, tal como aponta Frúgoli Jr. (2005), é necessário considerar que a presença marcante das classes populares no Centro da cidade mostra que não há sinais claros para se afirmar a respeito de uma efetiva elitização da região central, segundo este autor:

[...] o tema das classes populares perpassa as áreas centrais de nossas cidades de forma tão determinante, que mesmo as intervenções nos espaços públicos voltadas a princípio a uma gentrification de usos não podem deixar de lado a forte permanência de utilizações populares, bem como as inúmeras recriações ou contra-usos realizadas por esses grupos (FRÚGOLI JR., 2005, p. 13).

A estas considerações podem ser somadas as análises de D’Arc (2006, p. 286), que, numa outra perspectiva, considera não haver indícios de que as classes médias queiram realmente retornar ao centro de São Paulo, já que não encontrariam neste espaço "a satisfação de suas aspirações". Como lembra a autora, a multiplicação de shopping centers e condomínios fechados em São Paulo são provas de que esta classe média ainda está ligada a um outro tipo de consumo e serviço que não podem ser encontrados no Centro da cidade. Segundo D’Arc, a região central é ainda um lugar

\footnotetext{
${ }^{43}$ No capítulo 3 são analisados com maior especificidade os planos e estratégias da gestão Gilberto Kassab para a revalorização do Centro Histórico de São Paulo.
} 
onde predomina a pobreza, o que deixa entender que muito pouco se pode falar a respeito de um processo de gentrificação, pois “...o que se acentua nesse lugar central é uma extrema pobreza que 'impõe' sua presença nos espaços que se gostaria de ‘qualificar' por novas funções que não os incluem” (D’ARC, 2006, p. 289).

Não se pode negar que o Centro de São Paulo ainda concentra um contingente significativo de população de baixa renda e que as suas ruas são o lugar de moradia de centenas de indivíduos em estado de extrema pobreza ou marginalidade. Porém, parece ser inegável reconhecer, também, a existência de uma estratégia que pautada na revalorização deste espaço procura eliminar da região central os seus vestígios de pobreza. Tal estratégia se torna visível quando o poder público passa a negar o direito à moradia no Centro às classes populares; quando impõe limites ao uso do espaço público pela população mais pobre (a exemplo da instalação nas praças públicas dos chamados bancos e chafarizes anti-mendigos $)^{44}$, ou ainda quando incentiva a disseminação dos chamados espaços coletivos ${ }^{45}$ (Shopping Centers, Centro Culturais, etc.) criados para atender à população de maior renda que se espera atrair ao Centro Histórico da Cidade.

Neste sentido se a gentrificação ainda não é uma realidade em São Paulo, não é possível negá-la enquanto processo em constituição.

$\mathrm{Na}$ seqüência desta pesquisa serão consideradas outras variáveis que podem melhor iluminar as informações e análises propostas neste capítulo.

\footnotetext{
${ }^{44}$ Na recente reforma da Praça de Sé (localizada no Centro Histórico de São Paulo), dentre as diversas medidas efetivadas para coibir o seu uso pelos moradores de rua; pode-se mencionar a substituição de antigos bancos, por bancos menores que impedem que as pessoas deitem e durmam sobre eles e a construção de jardins alagados para impedir o acesso aos chafarizes (usados pela população de rua para tomar banho, etc.).

${ }^{45}$ Espaços que contemplam a mescla espaço público-privado.
} 
os Capítulo 2 


\section{cos Capítulo 2: Associação Viva o Centro x Fórum Centro Vivo: conflitos pelo uso e apropriação do espaço no Centro de São Paulo}

\subsection{A Associação Viva o Centro e o processo de Revalorização do Centro Histórico de São Paulo}

Analisar a revalorização do Centro Histórico de São Paulo pressupõe, necessariamente, considerar a atuação e o discurso elaborado pela Associação Viva o Centro. Esta afirmação se justifica, pois esta organização não-governamental é uma defensora implacável da revalorização deste espaço, e se constitui como um dos principais agentes ideológicos deste processo. Do mesmo modo, a sua atuação traz evidências para as contradições e acirra os conflitos existentes pela apropriação deste espaço, pois, embora se autoproclame a defensora e representante dos interesses de toda a sociedade pela em prol da revalorização do Centro Histórico de São Paulo, o seu discurso manifesta interesses particulares dos agentes que vislumbram novas possibilidades de reprodução do capital no Centro da cidade. Ao longo deste item serão retomadas e melhor desenvolvidas estas idéias.

Tendo sido fundada no ano de 1991, a Associação Viva o Centro - Sociedade Pró-Revalorização do Centro de São Paulo - é uma organização que congrega em torno de si, ao mesmo tempo em que representa, empresas e demais sociedades ligadas aos setores da indústria, comércio, serviços, finanças, cultura e turismo, que atuam no Centro Histórico de São Paulo e, como dito anteriormente, têm interesses específicos no seu processo de revalorização. Esta Associação foi idealizada por um grupo executivos ligados ao BankBoston ${ }^{46}$, tendo como premissa inicial implementar em São Paulo um projeto de revalorização da região central semelhante ao ocorrido na downtown de Boston (EUA) (ASSOCIAÇÃO VIVA O CENTRO, 2001).

De forma sintética, pode-se afirmar que a revalorização da região central de Boston, realizada a partir dos anos 70, consistiu na transformação de edifícios históricos - considerados degradados e ociosos - em espaços de consumo e lazer para as classes médias e para o estímulo do turismo local e internacional. Deste modo, conciliando recursos do poder público com interesses do setor privado, áreas tidas como degradadas

\footnotetext{
46 No início da década de 90 o sede do BankBoston já se localizava nas proximidades do Vale do Anhangabaú, local que naquela época passava por um processo de readequação urbanística e paisagística. O idealizador da Associação Viva o Centro, Henrique de Campos Meirelles, ocupa deste de 2003 o cargo de Presidente do Banco Central do Brasil.
} 
deram lugar aos chamados festival malls - espaços que concentram mercados, restaurantes, bares, lojas e escritórios -, que atraíram para o Centro um novo e volumoso contingente populacional, bem como, investidores do setor imobiliário ávidos pela valorização do preço do solo ${ }^{47}$ (DEL RIO, 2001). Entretanto, a "contrapartida" deste processo foi a remoção da população de menor poder aquisitivo (gentrification), como conseqüência dessa mesma valorização imobiliária e da alta dos preços dos aluguéis.

Entretanto, reconhecendo como exitosas as práticas de revalorização efetivadas em Boston, a Associação Viva o Centro declara, a partir do seu Estatuto (documento elaborado e registrado em 1991, que formaliza atuação da AVC), os seguintes propósitos para o Centro de São Paulo:

Contribuir para a revalorização histórica, arquitetônica e urbanística; [...] para a animação e efervescência cultural em todos os aspectos [...] Servir de canal de comunicação entre os associados e os órgãos e entidades de caráter público ou privado que tenham responsabilidade sobre o Centro ou comunguem com os interesses da Associação [...] Proteger, em Juízo e fora dele, o meio ambiente, o consumidor, a ordem econômica, a livre concorrência e o patrimônio artístico, estético, histórico, turístico e paisagístico do Centro... (ASSOCIAÇÃO VIVA O CENTRO, 2005).

Todos esses propósitos estão fundamentados em torno da idéia de que o Centro passa por um longo processo de degradação física, motivado pela migração de setores dinâmicos da economia para as novas centralidades da cidade de São Paulo, e pelo abandono dos investimentos do poder público e da iniciativa privada. De tal modo, e à maneira como o discurso da Associação Viva o Centro afirma, o Centro foi deixado à mercê da marginalidade, da ilegalidade e da desgovernança. Esta análise pode ser verificada pela avaliação do respectivo trecho:

Sem a afluência outrora maciça da classe média e mesmo de parte da população de menor renda (os ricos já estavam longe há décadas) em busca das suas atrações, cinemas, teatros, comércio, restaurantes e glamour, o Centro começou tolerar e absorver, como rotina, um semnúmero de práticas informais e/ou ilegais, o comércio improvisado nas calçadas, os usos predatórios [...] a região já se deixava ver pela opinião pública como um depósito das insolvências da cidade (ASSOCIAÇÃO VIVA O CENTRO, 2001, s.p.).

\footnotetext{
${ }^{47}$ Del Rio (2001) aponta que houve uma valorização de 20 a $25 \%$ do preço do solo em algumas áreas do centro de Boston, como resultado da sua revalorização.
} 
O que a Viva o Centro procura caracterizar como insolvências da cidade pode ser compreendido pela presença do comerciante ambulante, dos moradores de rua e de toda sorte de pobreza existente no Centro Histórico da cidade. A Associação denuncia tais "insolvências" como um conjunto de atributos que somente contribuem para uma maior deterioração da região, destoando da nova imagem que se pretende construir ideologicamente para este espaço: o centro como pólo cultural, de serviços e tecnologia, etc.

Portanto, é pela afirmação de que há um processo de franca deterioração do Centro Histórico de São Paulo que a Associação Viva o Centro se propõe inicialmente o desafio de reordenar o uso deste espaço - pela eliminação dos chamados usos predatórios - e enfatizar a importância da região central no contexto da metrópole de São Paulo. Entretanto, o que está em proposição, e que se camufla por meio da elaboração de um discurso baseado na promoção de uma pretensa animação e efervescência cultural do Centro, bem como, da proteção do patrimônio histórico; é um conjunto de estratégias ideológicas orientadas para valorização dos atributos econômicos do Centro. Em outras palavras, buscam reafirmar a lógica da reprodução do capital, por meio da produção de um espaço para apropriação privada pelos agentes que visam a ampliação dos seus investimentos e lucros no Centro da cidade - agentes que a própria Associação Viva o Centro mobiliza e representa.

Dentre os mais de oitenta associados que hoje estão representados pela Viva o Centro, podemos destacar: BankBoston, Bolsa de Mercadorias \& Futuros (BM\&F); Associação Brasileira de Bancos Internacionais (ABBI), Federação Brasileira das Associações de Bancos (FEBRABAN); Sindicato de Hotéis, Restaurantes, Bares e Similares de São Paulo; Bolsa de Valores de São Paulo (BOVESPA); Pinheiro Neto Advogados; Serviço Social do Comércio (SESC); Klabin; Faculdade de Direito da Universidade de São Paulo; Universidade Anhembi Morumbi; Mosteiro de São Bento de São Paulo; Ordem dos Advogados do Brasil (OAB); Fundação Bienal de São Paulo; Casas Bahia; Serviço de Apoio às Micro e Pequenas Empresas de São Paulo (SEBRAE); Federação das Indústrias do Estado de São Paulo (FIESP); Banco Itaú; Banco Santander Banespa; Sociedade Amigos de Vila Buarque, Santa Cecília, Higienópolis e Pacaembu; Associação Nacional das Corretoras de Valores, Câmbio e Mercadorias (ANCOR); e Associação Nacional das Instituições de Crédito, Financiamento e Investimento (ACREFI), etc. Muitas dessas instituições e empresas apresentam interesses na valorização imobiliária do Centro, como elemento de 
rentabilidade para seus investimentos e negócios, portanto apóiam financeiramente e dão aval ao discurso da Associação Viva o Centro. Deve-se salientar, ainda, que parte dessas mesmas instituições se constitui como agentes hegemônicos na sociedade brasileira, sendo assim, pelo poder econômico que representam, conseguem tanto influir nas decisões políticas tomadas desde a esfera municipal até a federal, quanto barganhar privilégios.

Ainda em relação aos propósitos da Associação Viva o Centro, deve-se observar que, além do que estava previamente estabelecido no seu Estatuto, esta organização não-governamental ultrapassou a condição de mero canal de comunicação entre os seus associados e os órgãos do poder público, tornando-se um agente que interfere na definição das políticas públicas para o Centro de São Paulo. Mais do que isso, pode-se dizer que a AVC pauta o debate (público) em torno da revalorização do Centro Histórico de São Paulo, constituindo-se, assim, como um importante agente ideológico desse processo. De um modo geral isto tem se tornado possível por meio da participação de membros da Associação nos mais diversos fóruns de discussão política do poder público. Como exemplo para esta afirmação, é possível fazer referência à participação da AVC nos respectivos órgãos do poder municipal: Comissão Executiva da Operação Urbana Centro - a AVC participou da elaboração do projeto de Lei que instituiu esta Operação Urbana e hoje atua na definição das suas diretrizes; Comissão PROCENTRO - a AVC é um dos gerentes do "Programa de Requalificação Urbana e Funcional do Centro de São Paulo"48; e o Conselho Municipal de Turismo da Prefeitura Municipal de São Paulo - este órgão estabelece a política de turismo e eventos da cidade da São Paulo e tem a AVC como um dos seus conselheiros ${ }^{49}$.

O poder de se fazer ouvir e de pautar as estratégias do poder público (no que concerne ao processo de revalorização do Centro Histórico) passa a ser tamanho que, nas eleições municipais de 2004, a Associação Viva o Centro submete aos candidatos à Prefeitura Municipal de São Paulo ${ }^{50}$ as suas "10 propostas" para revalorização do

\footnotetext{
48 Como será observado adiante, a AVC teve um papel imprescindível na própria constituição do PROCENTRO. Deve-se observar, ainda, que este órgão passou se constituir como um braço forte desta Associação nas instâncias do poder público municipal.

49 Ao longo deste trabalho analisaremos com maior profundidade a participação da Associação Viva o Centro junto aos órgãos da administração pública

50 Naquela ocasião foram escolhidos, pela Associação Viva o Centro, os candidatos com a melhor colocação nas pesquisas eleitorais, dentre eles, José Serra (PSDB) e os ex-prefeitos/candidatos Marta Suplicy (PT), Paulo Maluf (PP) e Luiza Erundina (PSB).
} 
Centro da cidade. O documento entregue aos candidatos, intitulado "Carta aos Candidatos" (ASSOCIAÇÃO VIVA O CENTRO, 2004), contempla os seguintes itens:

1 - Requalificação do Pólo Luz-Santa Ifigênia; 2 - Refuncionalização do Vale do Anhangabaú; 3 - Requalificação da rótula central; 4 Revisão do sistema de calçadões; 5 - Construção de garagens subterrâneas; 6 - Implantação de sistema circular de bondes; 7 Criação de espaços adequados ao comércio informal; 8 - Implantação de uma eficiente coordenação e gestão, pela Prefeitura, da rede de instituições públicas e privadas que atendem e/ou acolhem pessoas em situação de rua do Centro; 9 - Implantação de um sistema territorializado (por microrregião) de zeladoria urbana, segurança e fiscalização; 10 - Guichê Inteligente do Centro. (ASSOCIAÇÃO VIVA O CENTRO, 2004, s.p.).

As idéias que aqui estão colocadas consistem basicamente em estratégias que visam promover um novo uso do espaço na região central, reordenando-o e incentivando a sua refuncionalização: por meio da sugestão de novos traçados para as ruas, numa clara intenção de facilitar o acesso do transporte individual no Centro; pelo estímulo ao investimento em equipamentos culturais, como fomento para a atividade turística e atração de um novo contingente populacional, em geral, com elevada capacidade de consumo; pela remoção e/ou segregação dos comerciantes ambulantes em lugares que fiquem fora da vista dos usuários da região central; pela fiscalização do Centro, como forma de controlar o uso do espaço, etc. Ou seja, um conjunto de propostas que apontam para um processo de segregação social e gentrificação do espaço urbano, fincado em uma ideologia que tem como conteúdo a mudança da composição social do Centro de São Paulo.

É importante observar que boa parte das idéias apresentadas pela Associação Viva o Centro, por meio de sua "Carta aos Candidatos", foram incorporadas às propostas da gestão José Serra/Gilberto Kassab (iniciada em 2005) no programa da Prefeitura para a revalorização do Centro Histórico de São Paulo. O que mais uma vez torna evidente a importância que assume o discurso da AVC perante as estratégias de intervenção urbanística na região central da cidade; ou ainda, a sua capacidade de pautar o poder público com os interesses particulares que defende e representa.

Da mesma forma que é "interlocutora" entre os interesses de diversos setores da iniciativa privada e o poder público, a Associação Viva o Centro gere e organiza, por meio das chamadas Ações Locais ${ }^{51}$, grupos de moradores, comerciantes ou empresários

\footnotetext{
51 Criadas no ano de 1995, as Ações Locais "são entidades sem fins lucrativos que, licenciadas pela Associação Viva o Centro, atuam, cada uma numa determinada microrregião do Centro de São Paulo,
} 
locais que atuam na zeladoria do Centro da cidade, buscando identificar possíveis distorções no uso do espaço e solicitando ao poder público o equacionamento dos problemas por eles identificados. As Ações Locais passam a ser mais uma instância de reivindicação e de pressão junto à administração pública, porém, defendendo amplamente a ideologia difundida pela Associação Viva o Centro. São funções das Ações Locais:

[Cuidar da] limpeza, iluminação, segurança, ocupação irregular do espaço público, população em situação de rua, poluição sonora e visual e de tudo aquilo que possa melhorar a qualidade de vida da comunidade e facilitar o funcionamento das empresas aí instaladas (ASSOCIAÇÃO VIVA O CENTRO, 2005, p. 2).

A partir da investigação que realizou sobre a atuação das Ações Locais no Centro de São Paulo, Frúgoli Jr. (2000) pôde identificar que, em geral, os grupos que compõem essas entidades são constituídos, além dos moradores, por comerciantes locais, cuja preocupação tem sido a de zelar pela valorização do seu patrimônio e evitar a permanência do comércio ambulante e dos moradores de rua na região central, de modo que passam a reivindicar ao poder público um policiamento mais ostensivo na região.

Embora a Associação Viva o Centro estabeleça que "as Ações Locais são entidades independentes entre si e em relação à Associação Viva o Centro", ou ainda, “As Ações Locais não podem falar em nome da Viva o Centro...” (ASSOSSIAÇÃO VIVA O CENTRO, 2005), sabe-se que os propósitos dessas entidades vão ao encontro das propostas lançadas pela Associação Viva o Centro para a revalorização da centralidade histórica de São Paulo. Deste modo, as Ações Locais procuram defender as mesmas medidas de reordenação e controle do uso do espaço que estão no bojo do discurso da AVC. Sendo assim, pode-se pressupor que a atuação de uma dá legitimidade ao discurso da outra, isto se torna evidente pela constatação de que é a própria AVC que delimita a área de atuação de cada Ação local, bem como, determina a estrutura de funcionamento e prescreve o conjunto de atividades que devem ser objeto da sua atuação - tal como consta no "Manual do Dirigente da Ação Local" (2003) elaborado pela própria Associação Viva o Centro.

servindo como canal de negociação entre a comunidade local e o poder público. Cada Ação Local objetiva melhorar a qualidade de vida das pessoas e as condições de operação das empresas e organizações estabelecidas em sua área de atuação" (ASSOCIAÇÃO VIVA O CENTRO, 2005, p. 2). 
Dito de outro modo, é possível constatar que as Ações Locais constituem uma tentativa da Viva o Centro de criar uma representação social junto às instâncias do poder público municipal, neste iminente contexto de revalorização do Centro Histórico de São Paulo. Isto tem se revelado possível a partir de uma estratégia de cooptação da sociedade pela própria Associação mediante a difusão de uma ideologia por ela mesma criada.

Retomando o discurso ideológico elaborado pela Viva o Centro, é possível constatar que a importância que a Associação atribui à região central tem como referência a relevância histórica desse espaço na formação de São Paulo. Deste modo, a Associação busca resgatar nas origens desta cidade os elementos que contribuem para a construção desse discurso, o qual se afirma pela necessidade de revalorizar o espaço que se constitui como o lugar de fundação da cidade e que até hoje guarda elementos que revelam o seu desenvolvimento ao longo dos séculos. Ao mesmo tempo, a retórica resgata que Centro é o lugar a partir do qual se construiu a história de pujança econômica de São Paulo, porque fôra exatamente o espaço onde se instalaram as primeiras fábricas e que, posteriormente, deram lugar a uma atividade comercial dinâmica, mas que hoje se encontra em patente processo de declínio e/ou degradação. Portanto, o que se procura induzir por meio destes argumentos é a idéia de que revalorizar o Centro seria a maneira de reconstruir ou retomar o seu vigor econômico.

Este discurso, em função do apelo nostálgico que o sustenta, incorpora elementos de fácil aceitação e assimilação pela sociedade, portanto, tenta promover um consenso em torno do projeto de revalorização do Centro Histórico de São Paulo. Como forma de estimular este convencimento, a Associação Viva o Centro lança mão de uma série de publicações impressas para divulgar a sua atuação e o seu ponto de vista sobre as questões relacionadas ao cotidiano da região. Essa estratégia tem como ponto de partida a veiculação do "Informe Viva o Centro" (publicado quinzenalmente e distribuído gratuitamente em vários pontos do Centro de São Paulo) e da revista "URBS - Viva o Centro" (publicada bimestralmente e comercializada por meio da venda de assinaturas e em bancas de jornal).

Estas publicações (com ênfase maior para a "URBS - Viva o Centro") contêm matérias e artigos, em geral, escritos pelos seus próprios editores, que defendem os mesmo pontos de vistas e discursos manifestados pela Associação Viva o Centro. Do mesmo modo, são veiculadas entrevistas com políticos e acadêmicos que procuram 
discutir - mas raramente questionar - temas em torno da revalorização do Centro Histórico de São Paulo.

Tanto a revista "URBS - Viva o Centro" como o "Informe Viva o Centro" têm como público alvo os próprios associados da Viva o Centro, além de empresários, acadêmicos, o poder público, jornalistas da imprensa escrita, rádio, TV, etc. (ASSOCIAÇÃO VIVA O CENTRO, 2006). Ou seja, a Associação espera não somente divulgar os seus argumentos aos agentes dos quais necessita para levar adiante a sua estratégia de revalorização do Centro Histórico da cidade, mas também atingir os setores da sociedade considerados formadores de opinião e, deste modo, fazer com que seu discurso seja reproduzido e chegue para o público em geral $^{52}$.

Nos últimos anos, embora a Associação Viva o Centro ainda faça uso de fragmentos de um discurso que afirma como necessária a revalorização do Centro Histórico pelo resgate da sua história e importância econômica na cidade de São Paulo, ela procurou atualizar esta retórica frente os novos acontecimentos que inserem a metrópole paulistana no contexto da globalização econômica. Sendo assim, de acordo com a AVC, as estratégias que hoje promovem a revalorização da região central da cidade devem propiciar uma nova dinâmica urbana para este espaço, gerando uma ampla malha de serviços e de infra-estrutura, que permitam à cidade de São Paulo conectar-se à rede de economias mundiais ou de Cidades Mundiais (Almeida, 2001). Deste modo, como afirma a Associação Viva o Centro:

[...] o Centro metropolitano de São Paulo, sendo a região onde as contradições inerentes ao processo de metropolização se apresentam em sua forma mais atual, densa e a um só tempo problemática e promissora, é o lócus de onde deverão surgir as respostas para os formidáveis desafios urbanísticos, sociais e econômicos que se colocam para a inserção de São Paulo na ordem mundial globalizada. Visto até aqui como um território insolvente, ele é na realidade o território fecundo de São Paulo. Mercê de sua própria condição histórica, de sua carga simbólica, da qualidade coletiva e cívica de seus espaços e de seu extraordinário potencial, o Centro Metropolitano é a única região a partir da qual se poderá elaborar um projeto da cidade compatível não só com suas demandas sociais e de participação democrática na condução do seu destino, mas também com a relevância que São Paulo assume no âmbito do Mercosul e da economia mundial (ASSOCIAÇÃO VIVA O CENTRO, 1996, p. 3, grifos nossos).

\footnotetext{
${ }^{52}$ A própria Associação Viva o Centro calcula que semanalmente haja 50 mil leitores do "Informe Viva o Centro" (cuja tiragem é de 18 mil exemplares) e outros 50 mil leitores da revista "URBS-Viva o Centro" (cuja tiragem bimestral é de 18.500 exemplares), o que atinge um número considerável de pessoas (ASSOCIAÇÃO VIVA O CENTRO, 2006).
} 
Evidencia-se, desta maneira, uma "atualização" do discurso da Associação Viva o Centro, que passa se afirmar pela necessidade de reconhecer o Centro não mais como um espaço deteriorado, cuja reordenação e revalorização é premente, mas sim, como um "território fecundo", onde se encontram as possibilidades de ajustes da metrópole às demandas impostas pelo mundo globalizado. Neste caso, o Centro de São Paulo passa a ser compreendido e divulgado como o lugar profícuo para conter e irradiar os vetores da economia mundial.

Contudo, é necessário considerar que, embora o discurso tenha assumido outra roupagem, os ideais defendidos pela Associação Viva o Centro continuam basicamente os mesmos ao longo dos anos. Dentre esses ideais, pode-se destacar, a defesa do patrimônio imobiliário daqueles agentes que têm capitais investidos no Centro de São Paulo, e que hoje lutam por uma nova valorização de tais investimentos. Deste modo, as novas abordagens e discursos não eliminam as velhas práticas, ou seja, coloca-se, em tese, outra discussão, que é aquela de pensar a cidade e a sua produção a partir de uma nova conjuntura, que corresponderia à sua inserção na chamada redes de economias globais. Porém, isso ocorre reafirmando os mesmos preceitos que, baseados na afirmação da desigualdade e da segregação sócio-espacial dos seus habitantes, há anos determinam a produção do espaço na cidade de São Paulo, neste caso: a reprodução capitalista da cidade, sua apropriação privada pelos agentes hegemônicos e a remoção da população mais pobre para as periferias urbanas.

A seguir serão retomados os discursos da Associação Viva o Centro em prol da revalorização do Centro Histórico de São Paulo, porém, buscando enfatizar os seus argumentos a respeito do problema da habitação na região.

\subsubsection{O posicionamento da Associação Viva o Centro em relação à habitação na região central}

Dentre os ideais que a Associação Viva o Centro tem buscado difundir, por meio do discurso que elabora, inclui-se a defesa da produção de uma centralidade que tenha como característica principal a sua multifuncionalidade, ou seja, que concentre tanto atividades estritamente econômicas, como desenvolva o seu "potencial habitacional, cultural e turístico". Segundo a Associação Viva o Centro:

Diversidade funcional é o principal atributo de uma centralidade metropolitana. Na área central de São Paulo é necessário potencializar as funções existentes e estimular o surgimento de outras. A função habitacional é básica para esse propósito. Outras funções, como a vida 
noturna, a cultura, o lazer, a hotelaria, os serviços especializados, devem ser fortemente estimulados. [...] Existe hoje consenso que a monofuncionalidade pode tornar-se um fator corrosivo no interior das cidades. Atividades pouco diferenciadas produzem espaços homogêneos, indistintos, pouco vitais. (ASSOCIAÇÃO VIVA O CENTRO, 1996, p. 6 e 20).

Em que pese à questão habitacional, a Associação Viva o Centro passa a divulgar que, "a ocupação do Centro para uso residencial socialmente diversificado, mais do que um complemento, é um imperativo de caráter estratégico [para a revalorização do Centro Histórico de São Paulo]" (ASSOCIAÇÃO VIVA O CENTRO, 2001, s.p.). Deste modo, passa a manifestar os seus anseios para que o reforço habitacional da região propicie o uso do espaço durante as 24 horas do dia, e que a presença dos novos moradores se converta em demanda por novos serviços privados e por mais investimentos do poder público para valorizar a região..

Embora se manifeste favorável pelo reforço da função habitacional no Centro Histórico da cidade, a Associação Viva o Centro expõe claramente os limites que esta estratégia deve alcançar. Deste modo, afirma que "a ampliação do uso residencial do Centro é um imperativo da estratégia de requalificação de áreas centrais, não podendo ser considerada uma ação de política habitacional" (ASSOCIAÇÃO VIVA O CENTRO, 2002, s.p.). Portanto, o que a Viva o Centro procura ideologicamente argumentar é que no Centro Histórico cabem alguns poucos projetos habitacionais que permitam fortalecer o seu uso residencial ou que contribuam para a sua revalorização. Porém, aponta claramente que a região central não é o lugar apropriado para solucionar os problemas habitacionais da cidade.

$\mathrm{Na}$ contramão do que defendem os movimentos de moradia do Centro da cidade - que reivindicam ao poder público políticas para habitação de interesse social nesta região - a Associação Viva o Centro sustenta que "um programa bem sucedido de uso residencial do Centro será importante por seu significado simbólico, não como atendimento à demanda por moradia na cidade" (ASSOCIAÇÃO VIVA O CENTRO, 2002).

O que a Associação Viva o Centro procura sugerir é que a função habitacional se estabeleça como uma dentre as demais funções que conformariam a chamada diversidade funcional (ou multifuncionalidade) do Centro Histórico de São Paulo. Entretanto é necessário desnudar essa ideologia para compreender que, diferentemente do que o discurso quer fazer parecer, a idéia em questão é a de afastar do Centro 
qualquer possibilidade de uso habitacional pelas classes populares ou de baixo poder aquisitivo. Neste sentido, é importante destacar que aquilo que a Viva o Centro denomina por "uso socialmente diversificado" do espaço, nem de longe significa mistura social ou convívio entre diferentes classes sociais. Pelo contrário, há nas propostas da Associação uma clareza quanto aos que devem ser beneficiados por moradia no Centro de cidade, neste caso: artistas, universitários e funcionários públicos, ou seja, indivíduos considerados como consumidores em potencial.

Em contrapartida, a Associação sugere ao poder público que:

[...] é bom lembrar que para viabilizar projetos adequados de moradia no Centro [...] uma série de bairros centrais como Barra Funda, Bom Retiro, Pari, Brás, Mooca, Liberdade têm um enorme potencial para acolher grandes contingentes populacionais que contribuiriam não só para aumentar o número de moradores na região central como para minimizar - aí sim, efetivamente - o problema do déficit habitacional na cidade. (ASSOCIAÇÃO VIVA O CENTRO, 2004, s.p.).

Sendo assim, as possibilidades para um adensamento residencial na cidade que atenda a população de baixo poder aquisitivo, de acordo com o que sugere a Associação Viva o Centro, não se encontram no Centro Histórico da cidade de São Paulo - que corresponde ao eixo/núcleo de revalorização de todo o centro da cidade -, mas sim nas áreas que estão adjacentes a esta região. De tal modo, pode-se afirmar que a perspectiva de uma densa ocupação residencial do Centro não seria compatível com o seu processo de revalorização, tendo em vista que os agentes privados, como aqueles ligados ao mercado imobiliário ou o setor da construção, têm outros planos para o uso e ocupação desta área.

Foi a partir desse posicionamento que a Associação Viva o Centro assumiu uma postura crítica em relação aos projetos habitacionais levados a cabo pelo poder público na gestão Marta Suplicy (2001-2004), quando edifícios desocupados do Centro Histórico de São Paulo foram reabilitados para moradia de população de baixa renda. Entretanto, tal como prevê esta Associação, a possibilidade destas áreas voltarem a se degradar é quase um fato, assim "estaríamos usando dinheiro público para criar um novo São Vito"53 (ASSOCIAÇÃO VIVA O CENTRO, 2004, s.p.).

\footnotetext{
${ }^{53}$ Neste sentido, a aposta da Associação Viva o Centro é que a habitação popular está sempre fadada à deterioração. A referência feita ao Edifício São Vito se deve ao fato deste edifício ter abrigado por longos períodos e sob condições calamitosas uma numerosa quantidade de famílias de baixa renda. No ano de 2004 o poder público promoveu a desocupação deste edifício para que fosse dado início à sua reforma, entretanto, este projeto não foi efetivado (atualmente, planeja-se a sua demolição). Até o período recente, as famílias que lá residiam não puderam retornar. Essas famílias passaram a ser assistidas pelo programa
} 
Já no início da gestão Marta Suplicy havia por parte da Viva o Centro uma profunda preocupação com os rumos das políticas a serem implantadas na região central da cidade. Esta preocupação tinha como foco central o receio de ser difundido, pelo poder público, um tipo de projeto que, invés de priorizar os interesses colocados pela própria Associação, fizesse do Centro um bairro para habitação das classes populares, e que neste sentido privilegiasse as demandas da população de menor renda. Esta preocupação está manifesta no seguinte trecho:

O problema é que o Centro, nos projetos e ações do poder público, ora parece ser tratado como centralidade principal, ora como bairro específico, com ênfase na ocupação residencial, principalmente por estratos sociais de menor renda. Falta, assim, uma política global de desenvolvimento dos atributos de centralidade, que inclua a habitação, decerto, mas com um peso apenas relativo e subordinada ao objetivo de dotar a metrópole de um centro complexo, poderoso e vital (ASSOCIAÇÃO VIVA O CENTRO, 2002).

Em nome de um pretenso fortalecimento e vitalidade do Centro da cidade, mais uma vez se evidencia o caráter ideológico das idéias que Associação Viva o Centro elabora e difunde e que, ao mesmo tempo, faz chegar ao poder público como se fossem demandas de toda a sociedade. Porém, como é possível entrever, expressam unicamente os interesses dos agentes que procuram encontrar na revalorização do Centro Histórico novas possibilidades de reprodução do seu capital. O que, evidentemente, se afirma em detrimento dos interesses e do uso desta centralidade pela população pobre ou de baixa renda, a qual é alvo costumeiro das políticas de segregação sócio-espacial.

Portanto, é pela concepção de que o Centro deve ser um produto para o consumo das classes de maior poder aquisitivo, que a Associação Viva o Centro procura defender, junto ao poder público, medidas para limpeza, segurança, melhor acessibilidade (por transporte individual) e disciplinamento do uso do espaço, por julgar que estes elementos são capazes de criar uma nova imagem da região e, por conseqüência, estimular um movimento atração das classes médias para o Centro. Deste ponto em diante, tal como observa a Viva o Centro, "a indústria imobiliária fará a sua parte, construindo novas edificações ou reformando as existentes para as faixas de renda média e média alta, como já se nota em alguns lugares” (ASSOCIAÇÃO VIVA O CENTRO, 2004, s.p.).

Bolsa-aluguel da Prefeitura de São Paulo, porém, em fevereiro de 2007 o programa foi extindo pela gestão Kassab. 


\subsection{O Fórum Centro Vivo e o processo de revalorização do Centro Histórico de São Paulo}

O conjunto das ações e das reivindicações do Fórum Centro Vivo expressam interesses que, em geral, se contrapõem àqueles manifestados pelo poder público e pelos agentes da iniciativa privada. Deste modo, evidenciam um conflito pelo uso e apropriação do Centro Histórico da cidade, o que constitui uma importante dimensão a ser considerada na análise do processo de revalorização desse espaço.

Salvo possíveis (mesmo que incorrendo em) generalizações, pode-se afirmar que enquanto o Fórum Centro Vivo manifesta os interesses dos movimentos populares que lutam pela vida no Centro e pelo direito de lá permanecer, do outro lado, a Associação Viva o Centro exprime um discurso de caráter elitista e defende os interesses dos agentes empenhados na preservação e valorização do patrimônio imobiliário existente na região central.

Em complemento a essas considerações, pode-se reafirmar que na revalorização do Centro Histórico de São Paulo as políticas e práticas do Estado tendem, na maior parte das vezes, a convergir com os interesses da iniciativa privada - como forma de levar adiante uma estratégia de transformação desse espaço, pela alteração do seu uso e do seu usuário, refuncionalização e reordenação do espaço -, privilegiando as demandas específicas dos agentes do capital. Entretanto, este processo não se realiza sem evidenciar uma dimensão eminentemente conflituosa, que se estabelece quando as classes populares passam reivindicar outra forma de apropriação desse espaço, consubstanciada, entre outras, por demandas pelo direito à moradia no Centro de cidade. Segundo Vieira,

As transformações ocorridas no centro de São Paulo, seja as que são fruto de investimentos privados, seja as que resultam de intervenções do poder público, não se dão à revelia das pessoas presentes na área [...] De fato, a implementação de qualquer tipo de transformação urbanística em um espaço público como o centro de São Paulo implica negociações e confrontos com aqueles atores que estão presentes nela e que serão afetados pelas transformações (VIEIRA, 2004, p. 82-83).

Deste modo, analisar a natureza desses conflitos constitui uma importante variável a ser considerada na compreensão do processo de revalorização do Centro Histórico. Porém, não somente porque os movimentos sociais que entram em conflito ou as vezes negociam - com os agentes da revalorização manifestam um outro interesse em relação ao uso e apropriação do espaço no Centro da cidade. Mas, também, porque 
eles tentam manter uma ação efetiva nesse processo de transformação espacial, seja pela resistência que impõe às práticas que consideram socialmente excludentes e desigualitárias, seja pela ação proponente que assumem na possibilidade de pautar o poder público com as suas reivindicações..

Ao longo dos últimos anos, diferentes movimentos sociais surgiram como resultado da organização da população moradora do Centro - reivindicando o direito de lá permanecer - ou de grupos de indivíduos que passaram a vislumbrar a possibilidade de fixar moradia nesta região. Pode-se citar como exemplo: a Unificação das Lutas de Cortiços; o Movimento de Moradia do Centro (MMC); o Fórum dos Cortiços; o Movimento dos Trabalhadores Sem Teto do Centro (MSTC), etc.

As reivindicações desses movimentos surgiram inicialmente como demanda pelo direito à moradia no Centro da cidade. Nesse sentido, atuavam basicamente promovendo a ocupação de edifícios ociosos da região central, como forma de pressionar o poder público pela promoção de políticas habitacionais para a população de baixo poder aquisitivo. No período recente, como sugere Evaniza Rodrigues, os movimentos sociais passaram a manifestar novas demandas, é neste sentido que a reivindicação pelo direito à moradia tende se converter em luta pelo direito à cidade. Deste modo, procuram demonstrar que, além da conquista do direito de morar, é necessário garantir que todos possam se apropriar, indistintamente, da cidade ${ }^{54}$.

Embora, os movimentos sociais passem a fazer um discurso em torno do direito à cidade, é necessário observar que, freqüentemente esta retórica é abandonada para que seja retomada a questão do direito à moradia, colocando a garantia à habitação como elemento prioritário das reivindicações das classes populares. Talvez se possa dizer que um discurso menos segmentado e mais universalista seja aquele produzido no bojo do Fórum Centro Vivo, que procura conciliar a reivindicação pela habitação, com a luta pelo trabalho, pelo uso do Centro e, portanto, pelo acesso da população aos equipamentos culturais, à infra-estrutura urbana, aos serviços públicos, etc.

Como forma de criação de um espaço de articulação entre os diferentes movimentos sociais que atuam no Centro de São Paulo desde os anos 90, foi fundado no ano de 2000 o Fórum Centro Vivo. Este fórum foi idealizado por estudantes da Faculdade de Arquitetura da Universidade de São Paulo (FAU/USP), pela Central dos

\footnotetext{
${ }^{54}$ Estas idéias têm como referência a fala proferida por Evaniza Rodrigues (Coordenadora da União Nacional por Moradia Popular) no Seminário "Produção Social do Habitat" e no "IV Congresso Brasileiro de Direito Urbanístico", realizados respectivamente em 21 a 24/11/06 e 5 a 8/12/2006.
} 
Movimentos Populares (CMP) e pela União dos Movimentos de Moradia (UMM). E se constituiu com a finalidade de promover o encontro, propiciar trocas entre os movimento e entidades sociais que lutam pela apropriação do espaço no Centro de São Paulo, que têm como causa comum o enfrentamento dos problemas suscitados pelas recentes estratégias de intervenção urbana efetivadas nesta região - processo, nesta pesquisa, denominado por revalorização do Centro Histórico de São Paulo.

A criação do Fórum Centro Vivo estava associada à necessidade de um espaço para encontro, debates, reflexão, articulação, fortalecimento mútuo e luta na perspectiva de democratização e defesa dos direitos no Centro da cidade, como contraponto aos projetos e ações públicas e privadas que, em muitos casos, desconsideravam e afetavam negativamente os grupos mais vulneráveis ou atendiam apenas a interesses privados e de ordem econômica e imobiliária (FÓRUM CENTRO VIVO, 2006, p. 1).

Neste caso, o que está designada como luta pela democratização e defesa dos direitos no Centro da cidade, segundo o Fórum Centro Vivo, pode ser entendida como luta pelo direito à moradia, trabalho, circulação e uso de um espaço privilegiado por infra-estrutura, serviços e empregos (FÓRUM CENTRO VIVO, 2006, p. 2). Esta luta se manifesta em oposição à "revitalização" movimentos e entidades como um processo que, em geral, promove a exclusão e segregação social da população vulnerável, ou seja, moradores de rua e cortiços, trabalhadores ambulantes, catadores de material reciclável, profissionais do sexo, etc. (FÓRUM CENTRO VIVO, 2006).

Embora os diferentes movimentos sociais que participam do Fórum Centro Vivo tenham as suas especificidades, no que diz respeito à sua organização e à definição dos seus objetivos, o Fórum representa a possibilidade de construção de uma pauta comum voltada, notadamente, à pressionar o poder público para o atendimento das demandas das classes populares e por garantir a permanência desses indivíduos no Centro da cidade.

No geral, os movimentos e entidades sociais que se aglutinam no Fórum Centro Vivo procuram se aproximar das instâncias de decisão do poder público, por meio da participação nos órgãos de representação social abertos à população. Neste caso, manifestando os interesses que estão presentes em sua Carta de princípios (que será

\footnotetext{
${ }^{55}$ Revitalização é, em geral, o termo utilizado no Fórum Centro Vivo para denominar o processo que, na presente pesquisa, designo por revalorização do Centro Histórico de São Paulo.
} 
apresentada posteriormente). Por outro lado, procuram dar visibilidade às suas demandas, por meio da organização de manifestações e atos públicos que chamem a atenção da sociedade para os conflitos existentes no Centro da cidade.

Congregam-se ao Fórum Centro Vivo: Central dos Movimentos Populares (CMP); Centro Gaspar Garcia de Direitos Humanos; Frente de Luta por Moradia (FLM); Integração Sem Posse; Movimento dos Ambulantes de São Paulo (MASP); Movimento Nacional de Luta em Defesa dos Direitos da População de Rua (MNPR); Movimento Nacional dos Catadores de Materiais Recicláveis - MNCR; Comitê Gestor da Praça Roosevelt; Pólis Instituto de Estudos, Formação e Assessoria em Políticas Sociais; União dos Movimentos de Moradia de São Paulo (UMM-SP); Ação da Cidadania; Centro de Mídia Independente - Coletivo de São Paulo (CMI-SP); Laboratório de Habitação e Assentamentos Humanos da Faculdade de Arquitetura e Urbanismo da Universidade de São Paulo (LabHab - FAU/USP); Marcha Mundial de Mulheres (MMM); Movimento dos Trabalhadores Sem Teto do Centro (MSTC); Movimento Passe Livre de São Paulo (MPL - São Paulo); Pastoral da Mulher Marginalizada (PMM) etc. (FÓRUM CENTRO VIVO, 2006).

Como se pode observar, apesar de ser numerosa a presença dos movimentos de moradia no Fórum Centro Vivo, se denota, por outro lado, uma composição marcada pela diversidade de agentes, que vão desde grupos ligados à universidade e institutos de pesquisa - que atuam, geralmente, prestando assessoria técnica aos movimentos sociais - passando por um grupo de mídia - que auxilia na divulgação das ações do FCV chegando até grupos sociais compostos pela população que vive marginalmente no Centro de São Paulo (como já especificado anteriormente: os catadores de material reciclável, moradores de rua, crianças e adolescentes em situação de risco, trabalhadores ambulantes, profissionais do sexo, etc.). Esta composição diversificada se reflete diretamente na pauta de atuação do Fórum Centro Vivo, que embora contemple os problemas que parecem ser comuns a todos os movimentos e entidades, a exemplo das questões relacionadas à moradia e ao uso do espaço urbano, passa a defender também os interesses mais particulares dos chamados "grupos sociais vulneráveis", cobrando do poder público políticas para inseri-los socialmente e que apontem para um outro caminho que não seja o da sua exclusão social.

A diversidade de movimentos e entidades sociais que se articulam em torno do Fórum Centro Vivo é, em parte, considerada pelos seus integrantes como uma característica positiva, na medida em que pode representar uma soma de forças às ações 
que estes movimentos pretendem efetivar. Entretanto, esta diversidade é, ao mesmo tempo, encarada como geradora de atritos. Isto ocorre principalmente quando, na tentativa de criar uma agenda comum entre os diversos movimentos, instala-se uma disputa entre esses grupos para fazer prevalecer uma ou outra demanda considerada prioritária $^{56}$.

Apesar do considerável número de movimentos sociais e entidades que integram o Fórum Centro Vivo, as sua reuniões ${ }^{57}$ são marcadas pela inconstância com que cada um desses grupos se faz presente. Tal situação pode ser compreendida pela dificuldade que os movimentos apresentam em conciliar as suas funções e atividades específicas com aquelas que são atribuídas no FCV. Do mesmo modo, o cotidiano de cada um dos indivíduos que estão ligados aos movimentos sociais, em função de uma rotina pessoal de trabalho, dos recursos financeiros escassos, entre outros, acaba por impor um limite a sua participação mais efetiva neste Fórum ${ }^{58}$.

Esta inconstância em relação à participação das entidades e movimentos sociais é compreendida, pelos próprios integrantes do Centro Vivo, como uma das fragilidades deste Fórum, na medida em que entendem que estas ausências geram dificuldades em relação à continuidade das suas ações e, também, se tornam um impeditivo para uma maior união dos próprios movimentos sociais.

Já em relação ao papel do Fórum Centro Vivo, há um relativo consenso entre os seus integrantes de que ele se constitui como um espaço de articulação, debates e fortalecimentos entre os movimentos e entidades sociais. Todavia, existe internamente um questionamento em relação a sua função, pois parte desses integrantes cobra que o FCV se constitua ou assuma uma prática similar àquela adotada pelos movimentos sociais, e que, portanto, não seja somente um espaço de articulação desses grupos. Conquanto não haja um consenso absoluto em relação ao papel do Fórum Centro Vivo,

\footnotetext{
56 A exemplo desta situação é possível fazer referência à reunião entre o Fórum Centro Vivo com os representantes do poder público municipal e da Guarda Civil Metropolitana realizada na Prefeitura de São Paulo em 01/02/2007. Este encontro tinha como objetivo discutir o problema da violência policial para com os catadores de material reciclável e com os moradores de rua; embora esse fosse o tema estabelecido para a discussão, os representantes dos movimentos de moradia impuseram uma outra pauta na reunião (ou a sua pauta específica) causando, posteriormente, uma discussão interna no Fórum Centro Vivo.

${ }^{57}$ Que ocorriam semanalmente na sede do Instituto Pólis.

${ }^{58}$ Entretanto, deve-se afirmar que há uma certa regularidade em relação à participação do Movimento de Moradia do Centro (MMC), do Movimento de Nacional dos Catadores de Materiais Recicláveis (MNCR), do Comitê Gestor da Praça Roosevelt, do Centro Gaspar Garcia de Direitos Humanos, de alguns pesquisadores do Instituto Polis e de estudantes universitários.
} 
por outro lado, os movimentos sociais convergem incondicionalmente na idéia de que a sua ação coletiva tem como finalidade a luta pela apropriação e pelo direito de permanecer na região central, e contra o seu processo de revitalização.

Deste modo, em um sentido que consideram oposto ao da "revitalização" do Centro de São Paulo, o Fórum Centro Vivo passa a sugerir a Reforma Urbana ${ }^{59}$ deste espaço. Tal com consta no documento "O Centro da Reforma Urbana: Manifesto por um Centro Vivo", por Reforma Urbana se pode entender:

[...] luta por um centro como lugar do povo, do direito à moradia, à cidade e à cidadania [...] a reforma urbana é pela reversão do processo de expulsão dos trabalhadores para as periferias [...] e democratização do acesso às áreas centrais [...] é a defesa de uma gestão democrática, com participação ampla e popular [...] É a luta para definir como inaceitável o domínio do individual sobre o coletivo... (FÓRUM CENTRO VIVO, 2004a, p. 1).

Ou seja, "Reforma Urbana" é tomada como sinônimo de uma luta por direitos que os movimentos e entidades articulados no Fórum Centro Vivo compreendem como essencial para a construção democrática da cidade. Entretanto, tais direitos seriam ignorados nos projetos de revalorização do Centro. Projeto este, baseado na valorização imobiliária, na segregação das classes populares, na privatização do uso do espaço; e que tem como norte os interesses dos setores empresariais e do capital imobiliário (FÓRUM CENTRO VIVO, 2004a).

É este mesmo entendimento em relação à produção da cidade que parece determinar os preceitos que regem a atuação dos movimentos e entidades sociais integrantes do Fórum Centro Vivo. Tais preceitos estão presentes na "Carta de Princípios" deste Fórum, a qual contempla os seguintes aspectos:

1 - Lutar por justiça social e pela reforma urbana, contra toda forma de segregação por classe social, raça, etnia, gênero, orientação sexual e faixa etária; 2 - Defender a função social da propriedade, contra a especulação imobiliária e a retenção de imóveis vazios, sejam estes públicos ou privados; 3 - Pleitear uma política de habitação popular para a área central com ampla participação, desde sua formulação até a execução e gestão; 4 - Apoiar as formas de produção e distribuição por cooperativas e empresas autogeridas, baseadas nos princípios da construção de uma economia solidária; 5 - Batalhar pelo uso democrático do espaço público e, por isso, contra o controle privatizado das ruas, calçadas e praças; 6 - Garantir a acessibilidade

\footnotetext{
${ }^{59}$ Nesta perspectiva, o Fórum Centro Vivo faz uma referência ao Fórum Nacional pela Reforma Urbana, cuja mobilização social, organizada ainda na década de 80 , tem como bandeira o direito à cidade e à cidadania: pela universalização do acesso aos equipamentos urbanos; pela gestão democrática da cidade, materializada no planejamento e na participação popular; e pelo direito comum à propriedade (GRAZIA, 2003).
} 
ampla ao centro, privilegiando o transporte coletivo e seu planejamento, a manutenção dos calçadões de pedestres e a redução de barreiras físicas para idosos, crianças e portadores de deficiência, opondo-se à ampliação da circulação de automóveis particulares; 7 Defender a preservação da história e da memória como patrimônio vivo, transformado no uso e na apropriação cotidianos e, assim, colocando-se contra a sua monumentalização e museificação; 8 Propugnar por uma política cultural que inclua o acesso democrático à produção, circulação e fruição dos bens culturais, assim como o direito à informação, como instrumentos essenciais à construção da cidadania e de uma cidade justa e solidária; 9 - Pôr-se contra o tratamento repressivo da população na área central (principalmente do povo de rua, de prostitutas, gays e travestis, crianças e adolescentes, encortiçados, movimentos populares e ambulantes); 10 - Questionar a legitimidade de operações urbanas e outras ações do poder público que tenham por fundamento um processo de valorização imobiliária, mesmo que sob a justificativa de gerarem contrapartidas sociais; 11 - Garantir a participação popular na Subprefeitura do Centro, nos conselhos de representantes e no orçamento participativo, na definição das políticas urbanas e no acompanhamento dos investimentos e serviços públicos na região; 12 - Apoiar os movimentos populares e outras formas de luta pelos direitos sociais no centro (como, por exemplo, o direito à moradia reivindicado nas ocupações de imóveis públicos vazios realizadas pelos movimentos)" (FÓRUM CENTRO VIVO, 2004b, p. 2-3, grifos do autor).

Como síntese das diretrizes presentes na Carta de Princípios do Fórum Centro Vivo, pode-se observar que a luta por justiça social e pela defesa de uma cidade democrática constituem o elemento aglutinador dos ideais que estão expressos neste documento. Neste sentido, dá-se a entender que as recentes estratégias políticas para transformação do Centro Histórico de São Paulo tendem a comprometer o uso e a apropriação do espaço pela sociedade em sua coletividade. É neste sentido que pode ser compreendida a defesa que o FCV faz pelo uso, sem controles, do espaço público; pela acessibilidade ao Centro por meio de transporte coletivo; pelo acesso de toda população aos bens culturais, entre outros.

Do mesmo modo, a perspectiva de valorização imobiliária da região, como decorrência do processo de transformação do Centro, parece determinar a elaboração de diretrizes que demandam por políticas de habitação popular nesta centralidade; ao mesmo tempo, passam a defender a efetividade da função social da propriedade - como modo de destinar para uso os imóveis ociosos existentes no Centro; e também a questionar os instrumentos urbanísticos considerados estimuladores desta valorização e especulação imobiliária, como é o caso das Operações Urbanas. 
Portanto, tal como é possível observar pela Carta de Princípios, o Fórum Centro Vivo parte em defesa de uma ocupação popular do Centro de São Paulo, propondo desde a participação das classes populares na definição das políticas urbanas, até o uso habitacional desta região como uma política a ser pleiteada junto ao poder público. Se de um lado esta questão da habitação popular é colocada pela constatação de que se faz necessário um aproveitamento dos espaços ociosos na região central; do outro lado, ela tende a se afirmar pela própria constatação dos movimentos sociais que um processo de revalorização do Centro Histórico de São Paulo redundaria na expulsão da população de baixa renda. Isso em função do estímulo à ocupação residencial da região pelas classes abastadas e pela elevação dos custos de moradia no Centro.

Talvez seja necessário esclarecer que o poder público não se opõe ao uso habitacional do Centro, muito pelo contrário, a questão da habitação está na ordem do dia no processo de revalorização do Centro Histórico de São Paulo que ele comanda. Como será visto adiante, existe na esfera pública municipal um consenso em torno da idéia de que reforçar a função moradia na região central é uma maneira de assegurar a sua revalorização. Como aponta Vieira,

Isso se deve ao fato de que o morar implica a necessidade de que se desenvolvam uma série de outros usos do espaço (educação, compras, saúde, lazer, transporte), que dinamizariam a economia e a ocupação da região, garantindo-lhe a possibilidade de uma recuperação efetiva e duradoura (VIEIRA, 2004, p. 91, grifo da autora).

Entretanto, o que parece fazer diferença em relação ao tratamento desta questão, diz respeito a quem se pretende beneficiar com uma política de habitação para o centro da cidade.

O Fórum Centro Vivo e os movimentos de moradia fazem a denúncia de que o reforço da função residencial do Centro, no contexto do atual processo de revalorização deste espaço, tende a beneficiar as classes médias ou os setores de maior poder aquisitivo. Esta tendência contraria os interesses destes movimentos, pois procuram defender a habitação no Centro para as classes populares, conforme já analisado anteriormente.

Embora no período recente o Fórum Centro Vivo denuncie o exclusivismo das políticas públicas do Estado, é relevante apontar que, outrora, as entidades e os movimento sociais conseguiram apresentar ao poder público parte das suas demandas. Isso ocorreu com maior precisão na última gestão do Partido dos Trabalhadores (PT) em São Paulo (2001 à 2004), com a prefeita Marta Suplicy. Naquela ocasião o poder 
público instituiu canais de participação à sociedade ${ }^{60}$, o que permitiu a estes movimentos expor as suas reivindicações e colher como resultado, a formulação de algumas políticas públicas ${ }^{61}$ voltadas à promoção e incentivo à habitação popular no Centro de São Paulo ${ }^{62}$.

Hoje, muito além do desejo de verem cumpridas as suas demandas, os movimentos sociais, que se articulam em torno do Fórum Centro Vivo, buscam formas de se inserir como agentes políticos da cidade, e atuar na definição das próprias políticas urbanas, tal como consta da Carta de Princípios já mencionada. É desta forma que continuam reivindicar a participação popular juntamente aos órgãos do poder público, porém, indicando que esta participação deve ter o caráter deliberativo e não, ou somente, consultivo.

Se até o ano de 2004 estas possibilidades de participação estavam relativamente abertas, em 2005, a partir do início da atual gestão municipal (tendo à frente o exPrefeito e atual Governador do Estado, José Serra, pertencente ao Partido da Social Democracia Brasileira - PSDB), grande parte dos canais de interlocução do poder público com a sociedade civil foi encerrado. Esta atitude, somada à realização de estratégias mais severas para controle do uso do espaço público, estabeleceram novos embates entre os movimentos sociais e o poder público no Centro da cidade.

Há um consenso, no interior do Fórum Centro Vivo, que as práticas levadas a cabo pela prefeitura municipal têm promovido um processo de "higienização" do Centro Histórico de São Paulo, o que se justificaria pela adoção de medidas que visam retirar a população pobre e ou marginalizada desta região, reprimindo-as por meio da ação policial. Como denuncia o FCV, estas práticas têm como resultado "o deslocamento e a expulsão da população mais vulnerável, mais pobre, com fortes indícios da produção do fenômeno da gentrificação, bem como limpeza, de caráter não só físico, mas também social” (FÓRUM CENTRO VIVO, 2006, p. 3).

\footnotetext{
${ }^{60}$ O Fórum Centro Vivo, assim como a Associação Viva o Centro, tinham assentos na Coordenação Executiva Provisória Ação Centro - um canal de participação dos cidadãos na discussão de diretrizes gerais dos programas e instrumentos de reabilitação e desenvolvimento do Centro -, pertencente ao Programa Ação Centro, por sua vez, responsável pela política de revalorização do Centro Histórico de São Paulo.

${ }^{61}$ Entretanto, como aponta o FCV, a política de habitação do poder público "foi alvo de diversas críticas de entidades e movimentos sociais participantes do FCV, por diversas razões, a exemplo da prioridade dada aos aspectos da valorização imobiliária como indicador de sucesso do programa, além da baixa proporção de recursos destinados a programas e projetos de inclusão social dos grupos mais vulneráveis, comparativamente aos outros investimentos previstos" (FÓRUM CENTRO VIVO, 2006, p. 3).

${ }^{62}$ Estas políticas públicas serão analisadas no capítulo 3.
} 
No sentido de trazer a público o que consideram como violações dos direitos humanos, o FCV organizou em 2006 um Dossiê para denunciar as infrações cometidas pelo poder público no Centro de São Paulo. Segundo o FCV a produção deste documento se justifica,

[...] porque é importante apresentar, no seu conjunto, uma série de acontecimentos que, se forem vistos de maneira fragmentada, ocultam uma prática sistemática do poder público, ou melhor dizendo, uma política de governo, que criminaliza as formas de resistência popular e desconhece as demandas por políticas públicas das camadas mais pobres de nossa população, demandas que a nossa Constituição reconhece como direitos de todos os brasileiros, no caso de todos paulistanos, sejam eles ricos ou pobres (FÓRUM CENTRO VIVO, 2006, p. 5).

Dentre as denúncias contidas no Dossiê, podemos destacar: a violação aos direitos humanos da população sem-teto, a partir da interrupção de programas de Habitação de Interesse Social na região central; a violação dos direitos humanos dos catadores de material reciclável, mediante a restrição à sua circulação no Centro de São Paulo; a ineficácia da política de atendimento à população de rua; a violência e perseguição aos trabalhadores ambulantes; a criminalização da pobreza, dos movimentos sociais e dos defensores dos direitos humanos; os retrocessos na democratização do Centro de São Paulo, do ponto de vista do uso e do acesso aos espaços públicos e equipamentos no Centro de São Paulo, bem como, da perspectiva da participação social (FÓRUM CENTRO VIVO, 2006).

No que diz respeito, especificamente, ao problema da habitação no Centro, o Fórum Centro Vivo procura demonstrar que mesmo diante de um expressivo déficit habitacional na cidade, contraposto a um elevado índice de vacância de imóveis no Centro, o poder público pouco tem feito para enfrentar esta contradição. Do mesmo modo, o Fórum faz a denúncia sobre a paralisação dos programas habitacionais populares; a não-aplicação dos recursos previstos em habitação para o município; o descaso com as famílias ameaçadas de despejo; o pagamento de benefícios para que as famílias dos sem-teto retornem para a sua cidade-natal, etc. (FÓRUM CENTRO VIVO, 2006).

Como elemento legal para amparar essa denúncia, o Fórum Centro Vivo procura fazer referência ao Estatuto da Cidade e cobrar, do poder público, a aplicação das normas nele presentes. Nesse sentido, reivindicam o cumprimento da função social da propriedade urbana, a aplicação dos instrumentos de parcelamento e edificação compulsória, bem como, a efetivação do IPTU progressivo, e a desapropriação com 
pagamento em títulos da dívida pública. Em relação a esse aspecto é importante ressaltar que, se o Estatuto da Cidade é marcado, ainda hoje, por uma contingência em relação à sua plena efetividade (pois, em parte, depende da vontade política dos representantes do Estado no sentido de enfrentar os interesses patrimonialistas existentes na cidade), por sua vez, os movimentos sociais não abrem mão de utilizá-lo como instrumento de cobrança por uma gestão democrática da cidade.

Ainda no tocante as reivindicações dos movimentos sociais é importante assinalar que não existe um questionamento da propriedade privada enquanto estrutura fundante da sociedade capitalista. Ao contrário, o que as lideranças demandam é acesso à propriedade privada, ou seja, sua distribuição mais justa e equânime. Neste sentido, deixam de considerar que é a instituição da propriedade privada que condiciona o uso e restringe a apropriação do espaço pelos cidadãos, produzindo, conseqüentemente, uma segregação sócio-espacial dos indivíduos. Porém, nos discursos dos movimentos sociais qualquer radicalidade é abolida para dar lugar a uma reivindicação por formas de acesso à propriedade, que passa a ser designada como luta pelo cumprimento da função social da propriedade. Deste modo, somente se avista de longe o cerne do problema, sem querer tocá-lo ou questioná-10 ${ }^{63}$.

Para além da importância dos temas e do conteúdo que o Dossiê apresenta, a sua elaboração pelo Fórum Centro Vivo, torna-se elemento de relevância à compreensão do processo de revalorização do Centro Histórico, porque expõe os conflitos existentes no Centro da cidade entre os diferentes setores que lá estão presentes, e que travam uma disputa pela apropriação e uso desse espaço. Deste modo, embora a ação do poder público, aliada aos interesses da iniciativa privada (cujo suporte ideológico é garantido pela Associação Viva o Centro), se faça hegemônica, ela encontra resistência na presença dos movimentos sociais na região central da cidade. A prática desses movimentos, ao mesmo tempo em que se opõe a uma estratégia que tende a estimular outra ocupação (social) do Centro, revela a dimensão conflituosa desse processo.

Se de um lado o Fórum Centro Vivo enaltece a "luta por um centro da vida, vivo pelo uso e apropriação coletiva de sua história e riqueza, um lugar por excelência onde se expressem igualmente os diferentes grupos sociais" (FÓRUM CENTRO VIVO, 2004, p. 1 grifos nossos); de outro lado, a Associação Viva o Centro "objetiva o desenvolvimento da Área Central de São Paulo, em seus aspectos urbanísticos,

\footnotetext{
${ }^{63}$ É nesse sentido que se pode entender que a demanda dos movimentos sociais é por uma "reforma" urbana e não por uma "revolução" urbana.
} 
culturais, funcionais, sociais e econômicos, de forma a transformá-la num grande, forte e eficiente Centro Metropolitano" (ASSOCIAÇÃO VIVA o CENTRO, 2006, grifos nossos).

Estas referências evidenciam os diferentes interesses que se estabelecem no tocante à apropriação do Centro Histórico de São Paulo. Enquanto os movimentos sociais produzem um discurso que aponta a importância do uso Centro pelos grupos sociais - nesse sentido, tendem a favorecer os interesses das classes populares que demandam, entre outras coisas, por habitação no Centro da cidade -; a Associação Viva o Centro elabora um discurso voltado para a transformação desse espaço, apontando para a importância de torná-lo um lugar de comando e concentração de poder (notadamente, político e econômico) da cidade - desta maneira, tende a favorecer os interesses dos setores que aguardam a valorização do Centro, como estímulo aos novos negócios e para própria reprodução do capital.

No processo de revalorização do Centro Histórico, o discurso propalado pela Associação Viva o Centro tem maior aceitação, isto porque, não difere das intenções que o próprio poder público, em geral, manifesta em relação à produção e apropriação desta centralidade. Entretanto, como a luta e a resistência dos movimentos sociais permitem entrever, esse processo se realiza em contradição com o uso e a apropriação do Centro ainda exercido e pretendido por uma numerosa parcela da sociedade.

No próximo capítulo serão analisadas as políticas de revalorização do Centro Histórico de São Paulo e os planos e estratégias para o seu reforço habitacional a partir do que foi proposto pelas diferentes gestões que administraram a cidade no período de 1991 a 2006. 
os Capítulo 3 


\section{us Capítulo 3 - O poder público e o processo de revalorização do Centro Histórico de São Paulo: o problema da habitação}

Apesar do consenso ou do reconhecimento da idéia de que reforçar o Centro como espaço de moradia da cidade é uma forma de assegurar a sua recuperação, este tema ganhará diferente tratamento ao longo das distintas gestões municipais que administraram a cidade de São Paulo entre os anos de 1991 e 2006. Cada uma dessas gestões estabeleceu, ao seu modo, um plano de revalorização do Centro Histórico e a ele vinculou uma proposta de uso habitacional para este espaço.

\subsection{Gestão Luiza Erundina - Partido dos Trabalhadores (1989-1992)}

No período que está compreendida a gestão Luiza Erundina, torna-se notória a formação de um consenso em torno da idéia de que a revalorização do Centro Histórico está circunscrita à realização projetos habitacionais para esta região. Contudo, pôde-se constatar, por meio da análise dos documentos produzidos naquela época, que a proposta habitacional para o Centro Histórico da cidade aparecia inicialmente deslocada da discussão em torno do seu processo de revalorização. Ou seja, o plano de "recuperação" desta centralidade, tal como expresso no documento "O Resgate da Área Central" (SÃO PAULO, 1991a), não contemplava de modo direto e explícito esta discussão, entretanto, apresentava um encaminhamento à produção imobiliária da cidade ao oferecer, por meio da realização de uma Operação Urbana, os incentivos e os fundamentos legais para que a iniciativa privada promovesse um novo uso e ocupação da área.

As discussões em torno da revalorização do Centro Histórico na gestão Luiza Erundina (1989-1992) foram antecedidas por um debate entre os diferentes setores que compunham a administração pública, que percebiam que a alocação de investimentos para recuperar a região central da cidade de São Paulo poderia despertar uma contradição no próprio discurso político deste governo, que se promovera sustentando a idéia de realizar inversões na periferia da cidade, tendo em vista, que o Centro havia sido ao longo da história uma área concentradora de recursos públicos, em detrimento da região periférica. De acordo com Roberto Mac Fadden ${ }^{64}$, os investimentos no Centro se justificavam, pois,

\footnotetext{
${ }^{64} \mathrm{Na}$ época vice-presidente da Empresa Municipal de Urbanização.
} 
[...] o habitante da periferia trabalha no centro da cidade. É a análise desse fato que proporcionou a necessária clareza ideológica que dava suporte à justificativa para se investir na área central. Nesse quadro, constatamos que houve equívoco na gestão Mário Covas [1983-1985], que abandonou o centro da cidade, sob o entendimento, errôneo, de que aqui estava tudo pronto e seria melhor, portanto, investir na periferia. A administração dele não percebeu que os moradores de uma metrópole como São Paulo ocupavam a cidade dinamicamente: de dia, em um lugar; à noite, em outro. (SÃO PAULO, 1991a, p. 02).

Resolvido o embate, deu-se início às obras que compuseram o processo de revalorização do Centro Histórico na gestão Luiza Erundina. Dentre tais obras, pode-se destacar aquela que promoveu a reurbanização do Vale do Anhangabaú - um projeto que, apesar de concluído na gestão Luiza Erundina, se iniciou na administração de Reynaldo de Barros (1979-1982) - com a construção de um túnel subterrâneo que ligou a Praça da Bandeira à Avenida Tiradentes, e liberou a área em superfície para o uso exclusivo dos pedestres. Conforme consta no material de divulgação desta obra FIGURA 4 -, os ideais que nortearam a "readequação urbanística e paisagística" da área foram a busca de segurança para o trânsito e a transformação das condições ambientais do Anhangabaú, que, após a sua reurbanização, passaria a ser "o novo cartão postal de São Paulo" (PREFEITURA DE SÃO PAULO, 1990). Do mesmo modo, afirmava-se que estas reformas se tornariam indutoras de novos investimentos do capital privado no Centro da cidade, o que em tese contribuiria para a sua revalorização.

Reafirmando este contexto de revalorização do Centro Histórico de São Paulo, a Prefeitura do município, por meio da Secretaria de Habitação e Desenvolvimento Urbano, lançou no ano de 1992 o "Projeto Eixo Sé-Arouche: Programa Piloto de Ordenação da Paisagem da Área Central" (SÃO PAULO, 1992), com o objetivo de promover mudanças paisagísticas na região, mediante: reordenação do conjunto mobiliário do Centro; alteração das fachadas dos edifícios; controle da poluição visual etc. Ou seja, uma estratégia que poderia criar outra imagem do Centro, que pusesse fim a uma idéia de espaço deteriorado, compreendida como um dos elementos causadores da recusa de parcelas da população, dos comerciantes e investidores em voltar ou reinvestir no Centro da cidade. 
Figura 4: Folheto com propaganda do projeto de reurbanização do Vale do Anhangabaú

\section{OAnhangabaú reurbanizado para tiraro barulho, o trânsito e a poluiçã̃o.}
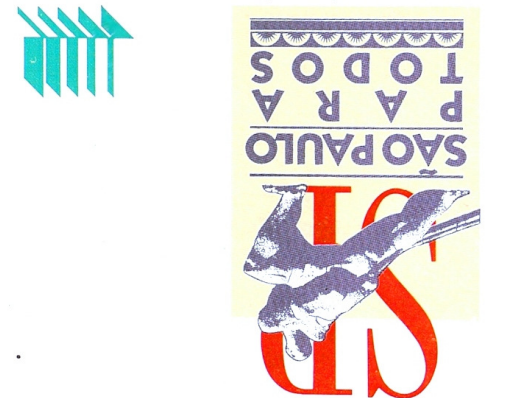

\section{Anhangabaú. Onovo cartão postal de São Paulo.}

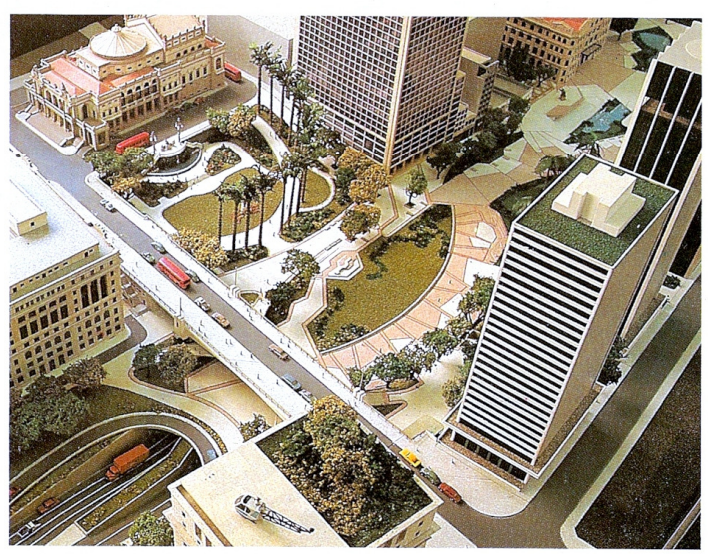

Fonte: (SÃO PAULO, 1990) 
Além das obras no Vale do Anhangabaú e no eixo Sé-Arouche, realizaram-se intervenções urbanísticas na Avenida São João, a partir de um projeto intitulado "Boulevard São João", que previa a implantação de calçadões para a livre circulação de pedestres em áreas onde antes, preferencialmente, circulavam veículos. Este projeto acentuou uma política de pedestrianização ${ }^{65}$ das ruas do centro da cidade, que ganhou vulto na gestão Luiza Erundina. Soma-se a estas intervenções, as obras realizadas no Parque Dom Pedro II, com vistas à reordenação deste espaço, buscando torná-lo adequado à instalação da nova sede do poder público municipal (que, até então, localizava-se no Parque do Ibirapuera). A referência a esta obra faz-se importante, pois ela se torna um elemento simbólico do processo de revalorização do Centro Histórico de São Paulo ao expressar a volta do poder ao centro, muito embora, essa transferência seja corporativamente justificada como se fosse apenas um "estímulo a outras obras capazes de alterar profundamente a feição daquela área...” (SÃO PAULO, 1991a, p. 1).

As transformações que estavam sendo realizadas no Centro, já contavam com o suporte ideológico da Associação Viva o Centro que, conforme referido em passagens anteriores, se constituiu formalmente no ano de 1991 e logo passou a atuar como instância de representação dos interesses dos setores empresariais e dos proprietários de imóveis junto ao poder público, o qual afirmava à época: "um dos principais motivos da recuperação do centro de São Paulo é trazê-lo de volta como referência aos cidadãos. Para isso é preciso que o poder público e a iniciativa privada estejam juntos, pois o interesse é todos" (SÃO PAULO, 1992, p. 24).

Seguindo esta perspectiva de que era necessário criar estímulos para atrair investimentos privados para o Centro Histórico, como forma de impulsionar o seu processo de revalorização, o poder público lançou mão de outros recursos para promover a região e captar tais investimentos. Neste caso, se faz referência especificamente à venda ou concessão onerosa do direito de construir acima dos potenciais fixados pela lei de zoneamento que vigorava na região. Este instrumento legal estava preconizado na Operação Urbana Anhangabaú ${ }^{66}$ aprovada pela Câmara Municipal de São Paulo como Lei Municipal no 11.090 no ano de 1991.

\footnotetext{
${ }^{65}$ Esse termo passa a ser empregado pelo poder público para nomear o processo de fechamento de vias de tráfego de veículo para a circulação exclusiva do pedestre.

${ }^{66}$ Apesar de já constar como um instrumento para intervenção urbana a ser utilizado por esta gestão, a Operação Urbana obteve caráter de lei federal após a regulamentação do Estatuto da Cidade no ano de 2001.
} 
A Operação Urbana Anhangabaú, ao mesmo tempo em que legalizava a venda de potencial construtivo, determinava que os recursos obtidos com esta venda deveriam ser alocados na área circunscrita a esta operação. Deste modo, permitia ao poder público realizar novos investimentos na área, dinamizando-a, valorizando-a e tornado-a ainda mais atraente aos interesses dos agentes privados, em especial àqueles que compõem o chamado setor imobiliário ${ }^{67}$. Além do que, eliminava as restrições em relação à verticalização da cidade que estavam impostas pela Lei de Zoneamento (adotada em 1972), até então, em vigência.

Para além da possibilidade de comercialização do solo urbano entre o poder público e a iniciativa privada, as Operações Urbanas passaram a se constituir como o regulamento oficial para a parceria público-privada que, na atualidade, assume status de parceria imprescindível à produção do espaço. Esta suposta "relação societária" se consubstancia frente à retórica de que o Estado não tem capacidade de arcar com o ônus da transformação dos espaços, entretanto, dispõe de poder normativo e de intervenção no espaço público. Já a iniciativa privada, por não dispor de tais atributos, coloca à disposição do Estado os seus recursos e, como contrapartida, tem a garantia da flexibilização da legislação. Tal medida, por sua vez, possibilitaria aos agentes privados promover a expansão dos seus negócios, bem como, captar a valorização decorrente dos investimentos feitos pelo poder público, neste caso, utilizando os recursos provenientes da venda de potencial construtivo, que seriam obrigatoriamente alocados nesta região.

Ao mesmo tempo em que essa valorização abria a possibilidade de ganhos rentistas ao setor imobiliário e aos demais agentes privados, ela poderia, por outro lado, ter implicado na impossibilidade de permanência da população de menor renda nesta mesma região em função do aumento do valor dos aluguéis e do seu impacto sobre a renda de tais famílias. Entretanto, apesar do revés social que esta medida poderia ocasionar, a discussão deste ponto sequer foi abordada no plano de revalorização do Centro Histórico de São Paulo proposto pela Empresa Municipal de Urbanização (Emurb).

Deve-se apontar que havia na Emurb um discurso que associava a deterioração da região central à sua popularização. Sendo assim, se as estratégias e as práticas

\footnotetext{
67 As primeiras intervenções programadas com recursos da Operação Anhangabaú foram: “a transformação da rua Xavier de Toledo em bulevar [...] implantação de calçadão na rua Sete de Abril [...] restauração de esculturas da praça Ramos de Azevedo, reforma da fonte dos desejos e instalação do Museu do Teatro Municipal nos baixos do viaduto do chá (SÃO PAULO, 1991, p. 26).
} 
efetivadas, com vistas à revalorização do Centro Histórico, objetivavam combater as causas da sua deterioração; logo a permanência das classes populares não era vista com bons olhos. Tal fato pode ser inferido à análise de Jorge Ciancio ${ }^{68}$ :

Curioso é que o processo de migração de empresas e instituições, do centro de São Paulo para outras áreas, possibilitou o aparecimento, na região central, de outro perfil de usuários. O centro, aos poucos, foi sofrendo um processo de degradação. Isso porque se acentuou o fenômeno dos cortiços e se aguçou a consequiente decadência de ambientes antigamente considerados nobres (SÃO PAULO, 1991a, p. 2).

Talvez haja nesta referência um indício que justifique a ausência de um debate em torno do ônus social que poderia advir de uma valorização imobiliária do Centro de São Paulo. Novamente, aqui, a frequiência de populares (população encortiçada) é vista como indício da degradação deste espaço.

Todavia, uma discussão a respeito da permanência da população pobre no Centro foi contemplada em projetos específicos elaborados pela Secretaria da Habitação (SEHAB) em parceria com a Superintendência de Habitação Popular (HABI), onde se manifestava a intenção do poder público em promover habitação social na região central de São Paulo. Tal como analisado por Diogo (2004), é no documento denominado “Cortiços: Programa de Habitações Populares da Região Central de São Paulo" que foi apresentada uma proposta de melhoria das condições de moradia da população que residiam em cortiços no Centro de São Paulo. Estas propostas tinham como objetivo zelar pela permanência desta população de baixa renda na região.

Uma das medidas tida como exemplar, na gestão Luiza Erundina, foi a reforma do imóvel localizado no número 849 da Avenida Celso Garcia, no bairro do Brás ${ }^{69}$, onde havia a proposta de transformar os cômodos existentes em apartamentos com melhor infra-estrutura; além de construir uma rede de serviços, tais como: creche, área de lazer e comércio, voltados para os 54 moradores daquele cortiço. Cabe ressalvar que a conclusão desta obra ocorreu após o ano 2000, durante a segunda gestão do PT com a Prefeita Marta Suplicy.

\footnotetext{
${ }^{68}$ Jorge Ciancio naquela época ocupava o cargo de chefe do Departamento de Projetos Urbanos da Emurb.

${ }^{69}$ Embora este projeto não se enquadre na delimitação espacial deste estudo, ele foi mencionado em função da importância que assumiu para a gestão Luiza Erundina como modelo de intervenção no Centro da cidade de São Paulo.
} 
Conforme constatou Diogo (2004), ao final de gestão Luiza Erundina foram propostas intervenções para a produção de 622 unidades habitacionais na Administração Regional Sé, entretanto, nenhuma delas foi concretizada até o final daquele mandato.

Além do programa de intervenção em cortiços, o poder público manifestou, por meio da elaboração do Plano Diretor de São Paulo no ano de 1991, a intenção de instituir Zonas Especiais de Interesse Social (ZEIS) no Centro de São Paulo. Estas ZEIS seriam voltadas à produção de habitação para população de baixa renda em áreas com concentração de cortiços - ZEIS 4 (SÃO PAULO, 1991c). Segundo Silva, H., "as primeiras ZEIS de cortiços [...] seriam delimitadas para vários conjuntos de quadras em bairros próximos ao centro histórico (19,79 hectares) onde [...] os agentes públicos e privados seriam obrigados a produzir HIS" (SILVA, H., 2000, p. 41). Entretanto, em função da reprovação do Plano Diretor pela Câmara de Vereadores de São Paulo, este instrumento também não efetivado.

Torna-se notório que o poder público, respaldado por suas secretarias (a exemplo da SEHAB) e empresas a ele associadas (como a EMURB), apresentava discursos divergentes em relação à questão da habitação e da revalorização do Centro Histórico de São Paulo. Há na verdade uma mescla de propostas que ora convergem para a defesa do interesse da população de menor renda - seja na questão da habitação, seja nas demais questões que envolvem o uso do espaço público -, ora caminham na direção dos interesses privados (como os do mercado imobiliário), tal como sugestionado pela lei municipal $n^{\circ} 11.090 / 91$, que regulamentou a Operação Urbana Anhangabaú.

Cabe ressaltar que, no quadro de intervenções propostas pelo poder público na gestão Luiza Erundina, a lei de Operações Urbanas foi - dentre a totalidade de intervenções propostas - a única medida que ao ser aprovada se efetivou ao longo desta gestão e obteve continuidade (não sem modificações) nas demais administrações públicas, sem que a sua validade e os seus efeitos fossem questionados. Por outro lado, medidas de caráter mais abrangente e de cunho popular, como a pedestrianização das ruas do Centro e os investimentos para reforma dos cortiços constituíam medidas que, quando não engavetadas, foram amplamente questionadas em algumas das gestões posteriores.

A exemplo do que foi afirmado acima, pode-se mencionar as medidas da atual administração municipal do Prefeito Gilberto Kassab. Nessa gestão, os calçadões são associados à deterioração do espaço urbano, sendo caracterizados como locus da 
marginalidade e da ilegalidade, bem como um entrave à "necessária" circulação dos automóveis pelas ruas do Centro Histórico de São Paulo.

O conjunto destes fatos aponta, ao longo do tempo, para uma tendência de produção do espaço onde os interesses da iniciativa privada se sobrepõem àqueles do restante da sociedade. O que coloca em xeque as possibilidades de uso e apropriação do espaço que podem ser realizadas por grandes parcelas da população, em especial aquelas de menor renda. Como será analisado a seguir, as intervenções propostas para o Centro Histórico de São Paulo na gestão Paulo Maluf (1993-1996) caminham nesta mesma direção.

\subsection{Gestão Paulo Maluf - Partido Progressista (1993-1996)}

Com o objetivo de reverter "o processo de deterioração, desvalorização e esvaziamento do Centro e conferir a ele, novamente, o estatuto que lhe cabe de direito" (SÃO PAULO, 1993, p. 06), em 1993 a gestão Paulo Maluf, por meio da Secretaria da Habitação (SEHAB), criou o Programa de Requalificação Urbana e Funcional do Centro de São Paulo, denominado PROCENTRO, visando com isto:

[...] impedir a instauração de um processo de declínio do Centro da Cidade de São Paulo [...] conjugando esforços públicos e privados que Sendo assim, considerem a diversidade de funções e interesses ali presentes.

[...] o PROCENTRO constitui-se num verdadeiro programa de ecologia urbana, com ações que visam criar novos e qualificados espaços públicos e privados, extirpar abusos de usos, rever soluções de visível fragilidade funcional e revitalizar funções hoje tolhidas por diversas razões (SÃO PAULO, 1993, p. 05-06, grifo nosso).

As propostas encaminhadas por meio da PROCENTRO partem da concepção de que o Centro Histórico era uma área cuja potencialidade ainda não havia se esgotado, entretanto, apresentava um uso "desgovernado" e "perdulário" frente à gama de recursos públicos ali investidos (SÃO PAULO, 1993). Neste sentido as ações de intervenção no Centro deveriam ser orientadas para reaver o prestígio deste espaço, de modo a resgatar antigas funções e estabelecer outras novas, como forma de atribuir-lhe novos usos que pudessem gerar valorização e não o desperdício do seu potencial.

Um dos elementos centrais do discurso do poder público, no tocante à revalorização do Centro Histórico, passa a ser o estímulo a uma suposta vocação cultural do Centro Histórico. Deste modo, há no bojo das propostas do PROCENTO um projeto designado "Plano de incentivo à cultura, lazer e turismo na região central" (SÃO 
PAULO, 1993). A idéia proposta era fazer um melhor aproveitamento dos equipamentos existentes no Centro, tais como: igrejas, bibliotecas, teatro, edifícios históricos, antigas salas de cinema; potencializando os seus atributos culturais e turísticos. Contudo, essas idéias podem ser compreendidas em uma outra perspectiva: como produção de espaços de consumo para as camadas de maior poder aquisitivo, por meio da refuncionalização e transformação de espaços pretensamente desqualificados.

Portanto, indo além de uma ideologia de transformação e criação de novos e qualificados espaços públicos e privados, ficava evidente a proposta de que a transformação do Centro passava necessariamente pela mudança do perfil social daqueles que faziam uso do espaço. Tendo em vista que naquela época o Centro se constituía como uma área eminentemente popular, seja pelo perfil do seu habitante, seja pelo padrão do comércio que ali se estabelecia, ou ainda pela imensa massa de trabalhadores que por ali circulavam cotidianamente, é possível dimensionar quem seriam os primeiros a serem afetados por esta transformação.

Quando da elaboração do Programa de Requalificação Urbana e Funcional do Centro de São Paulo, o poder público identificou quatro problemas a serem solucionados: 1) a deterioração ambiental e paisagística - constatava-se não haver uma ordem para a instalação dos equipamentos urbanos e mobiliários no Centro da cidade; o Centro era considerado visualmente poluído e com edifícios mal conservados; identificou-se problemas com a iluminação, bem como, com a coleta do lixo etc.; 2) A dificuldade de acesso, circulação e estacionamento - propunham-se medidas para rever a restrição do tráfego (calçadões), como forma de gerar maior acessibilidade automotiva às empresas; 3) A deficiência de segurança pessoal e patrimonial - apontava-se para a insegurança dos calçadões que propiciavam a circulação de um grande número de pessoas e a presença de barracas dos ambulantes ${ }^{70}$, ambos considerados como entraves à ação do Corpo de Bombeiros; a insegurança propiciada pela realização de grandes eventos na Vale do Anhangabaú, etc.; 4) A obsolescência e insuficiência do estoque imobiliário - a idéia era criar mecanismos que permitissem a modernização das edificações existentes e a construção de novos edifícios que atendessem a demanda das empresas (SÃO PAULO, 1993).

No que diz respeito ao último problema acima identificado, o plano sugeriu diretrizes para um novo projeto de Operação Urbana para o Centro, como forma de criar

\footnotetext{
${ }^{70}$ Além da existência de barracas nos calçadões ser considerada um problema, o Programa inclui como diretriz garantir a máxima restrição à concentração de comerciantes ambulantes na região central.
} 
novos estímulos para que a iniciativa privada voltasse a investir na região, modificando, assim, as condições do seu imobiliário. Tal como consta nas propostas do PROCENTRO, “o investidor apostará em uma reversão do processo de degradação do centro da cidade, se tiver razoável índice de segurança para tal. Ele necessita de garantias específicas sob forma de uma legislação especial para o centro da cidade" (SÃO PAULO, 1993, p. 19). É nesse sentido que a realização da Operação Urbana passa a legitimar uma estratégia de produção do espaço em que o Estado se auto-atribui a função de criar as condições ideais para a reprodução do capital - como se os benefícios a serem colhidos privativamente pelas empresas pudessem, em algum momento, ser compartilhados com toda a sociedade.

Dentre as diretrizes propostas para o novo projeto de Operação Urbana, a primeira a ser apresentada foi aquela que procurou estabelecer incentivos legais ${ }^{71}$ para a instalação no Centro da cidade de usos como: habitação, educação, lazer, cultura e hotelaria; visando com isto aumentar a "diversificação de usos na área central" (SÃO PAULO, 1993).

No que concerne à questão da habitação, pode-se entrever que a idéia proposta era incentivá-la por meio da realização do investimento privado. Portanto, o sentido de reforçar a função habitacional no Centro era criar meios para a produção de moradia pelo mercado imobiliário. Nesse sentido, propiciar a este setor maior rentabilidade face à isenção de impostos e à desobrigação do pagamento da contrapartida prevista na Operação Urbana Anhangabaú.

Sendo assim, a proposta de produzir novas habitações na região central pelo mercado imobiliário, cuja clientela é formada pelas classes mais abastadas, trazia subjacente a intenção de atrair para o Centro um contingente populacional de maior poder aquisitivo. Deste modo, pode-se observar que ao novo uso do espaço corresponderia um novo usuário.

A partir das análises realizadas e da investigação dos documentos elaborados pela Prefeitura de São Paulo foi possível observar uma relação de grande proximidade entre o poder público e a iniciativa privada cujos interesses são correntemente contemplados nos programas elaborados pela administração municipal. Conforme consta nos documentos do PROCENTRO:

\footnotetext{
71 Como disposto no Programa "estes incentivos podem prever, conforme o caso, autorização para ultrapassar os limites dos coeficientes urbanísticos com contrapartida reduzida ou nula, isenção de IPTU ou ISS por prazos estabelecidos, etc.” (SÃO PAULO, 1993, p. 20).
} 
A iniciativa privada tem objetivos e interesses claros quanto à questão da requalificação do Centro de São Paulo e do reaquecimento da demanda imobiliária. Alguns proprietários desejam a retomada da valorização de seus patrimônios, outros, melhores condições de percurso para seus clientes [...] É certo que esses propósitos em nada conflitam com os desejos de eficiência da administração pública. (SÃO PAULO, 1993, p. 19, grifos nossos).

O reconhecimento de que a iniciativa privada tem interesses próprios no processo de revalorização do Centro Histórico de São Paulo não traz um elemento novo à análise. No entanto, é altamente questionável o fato do poder público assumir como próprio os interesses da iniciativa privada.

Esta constatação de quase identidade entre interesses públicos e privados fica evidente, por exemplo, na constante referência à Associação Viva o Centro no Plano de Requalificação Urbana e Funcional do Centro de São Paulo (PROCENTRO). Há neste Plano o reconhecimento formal da Associação como "parceiro estratégico" do poder público para a elaboração de políticas para o Centro Histórico de São Paulo, bem como, para implementação das intervenções urbanísticas na região (SÃO PAULO, 1993). Como comprovação para tais afirmações, pode-se mencionar a nomeação em caráter oficial da Associação Viva o Centro como mediadora dos interesses da iniciativa privada junto ao Estado. O poder público atribui a esta Associação a responsabilidade pelo marketing e a participação na elaboração do projeto de Lei da nova Operação Urbana (SÃO PAULO, 1993).

Deste modo, é preciso recuperar que a criação do PROCENTRO como órgão público, teve como finalidade única atender à pressão ou contemplar as demandas colocadas pela Associação Viva o Centro. Portanto, o PROCENTRO passa se efetivar como instância de representação dessa Associação dentro do próprio poder público haja vista que a ideologia que o Estado manifestava em nada diferia daquela produzida pela Viva o Centro. Conforme atesta Simões Jr. (1994) “o PROCENTRO foi concebido tendo como marco inicial de estudo as propostas que já vinham sendo elaboradas pela Associação Viva o Centro" (SIMÕES JR., 1994, p. 59). Esse fato é reconhecido pela própria Vivo o Centro ao manifestar: "o PROCENTRO foi uma exigência da Viva o Centro [...] Nós não fazemos as leis, não temos poder de polícia, não somos poder público. Então a gente precisava realmente da parceria da prefeitura [...]" (BARRETO apud FRÚGOLI JR., 2000, p. 81). Ou ainda:

A Viva o Centro nasceu com a proposta de constituir-se em interlocutor entre a sociedade civil e o poder público para uma ação conjunta visando a requalificação do Centro. Como não havia nenhum 
órgão público especificamente encarregado de uma política para o Centro, foi preciso induzir a Prefeitura a criar um. Em julho de 1993 um decreto municipal cria o PROCENTRO, de cuja comissão executiva a Associação participa... (ASSOCIAÇÃO VIVA O CENTRO, 1997, s.p.).

Deve-se apontar que, durante boa parte da gestão Maluf, a atenção do poder público estava voltada notadamente à promoção de investimentos para a constituição de uma nova centralidade em São Paulo, localizada na Avenida Faria Lima. Como lembra Fix (2001), estes investimentos foram alocados na área de expansão do capital imobiliário, e mobilizaram recursos milionários do Estado para promover as infraestruturas demandadas pela iniciativa privada. Deste modo, o Centro Histórico da cidade, foi relegado, pelo menos momentaneamente, a segundo plano pelo poder público, o que talvez, tenha instigado a Associação Viva o Centro a cooptar o Estado para revalorizar a sua área de interesse.

É interessante notar que uma parceria do poder público com os movimentos sociais na definição de políticas para o Centro Histórico de São Paulo (o que supostamente poderia agregar um outro cunho à proposta de transformação do espaço), sequer é aventada como possibilidade. Ou seja, as camadas populares que habitam o Centro e os movimentos sociais não são chamados a tomar parte das decisões e das estratégias propostas para esta região. Esta mesma postura ganhará continuidade nos planos elaborados na gestão Celso Pitta (1997-2000).

\subsection{Gestão Celso Pitta - Partido Progressista (1997-2000)}

A gestão Celso Pitta retomou muitas das estratégias encaminhadas na gestão Paulo Maluf ${ }^{72}$, dentre as quais, a de tornar a instância decisória do processo de revalorização do Centro Histórico de São Paulo permeável à participação de representantes da iniciativa privada. Tal como está regulamentado na Lei ${ }^{\circ} 12.349$, que institui a Operação Urbana Centro - em substituição à Operação Urbana Anhangabaú de 1991 -, a Associação Viva o Centro, o Sindicato das Empresas de Compra, Venda, Locação e Administração de Imóveis de São Paulo (SECOVI), a Associação Comercial de São Paulo, entre outros, passaram a compor a Comissão Executiva desta Operação. Dentre as atribuições dessa Comissão Executiva estavam: a análise de propostas, a

\footnotetext{
${ }^{72}$ Deve-se ressaltar que Celso Pitta foi o candidato preparado por Paulo Maluf para ser o seu sucessor direto na administração municipal de São Paulo para o período de 1997 a 2000.
} 
emissão de pareceres e a elaboração de diretrizes para esta Operação ${ }^{73}$ (SÃO PAULO, 1997).

A Lei Municipal n 12.349/97 foi aprovada seis meses após o início da Gestão Celso Pitta. Conforme consta no documento "A Cartilha da Área Central":

Essa lei contém um conjunto integrado de incentivos que visam promover a reordenação urbanística da área central, através da atuação conjunta do poder público e da sociedade civil - empreendedores, usuários e moradores. O objetivo focal do instrumento é criar condições que reforcem a importância da área central para a metrópole de São Paulo, tornando-a atraente para investimentos imobiliários, turísticos e culturais e preparando-a para o papel de cidade mundial. (SÃO PAULO, 1997, p. 1, grifos nossos).

Na mesma direção das transformações propostas na gestão Paulo Maluf, o novo projeto de Operação Urbana formulado na gestão Celso Pitta contemplava, especificamente, a valorização do espaço no Centro Histórico de São Paulo por meio da concessão de uma gama de incentivos aos proprietários imobiliários e setores afins da iniciativa privada, que tivessem interesse em promover novos negócios na região e, assim, contribuir valorizá-1a ${ }^{74}$.

No que concerne à questão da habitação, a Operação Urbana Centro estabeleceu como uma de suas diretrizes o "incentivo à construção de habitações" (SÃO PAULO, 1997, p. 18). Esta diretriz se efetivaria pela concessão, sem ônus, do direito de construir aos interessados em promover habitação no Centro de São Paulo. O incentivo à função habitacional teve como objetivo animar a diversificação de usos na área central, contudo, conforme foi possível analisar em outros momentos, esta diversificação de usos do espaço não contempla necessariamente os interesses daqueles usuários (de menor renda) que já tem o Centro como lugar para habitação, lazer, trabalho, etc.

Um outro elemento a ser observado é que, dentre os documentos da administração pública analisados, pela primeira vez é feita uma referência explícita à proposta de tornar São Paulo uma cidade mundial ${ }^{75}$. A Operação Urbana Centro seria o

\footnotetext{
${ }^{73}$ Em relação a esta parceria público-privada, é importante notar que o que era uma diretriz do Programa de Requalificação Urbana e Funcional do Centro de São Paulo (PROCENTRO) na gestão Paulo Maluf, torna-se uma Lei Municipal na gestão Celso Pitta.

${ }^{74}$ A Operação Urbana Centro estabelece incentivos à produção imobiliária por meio da concessão de exceções à Legislação de Parcelamento Uso e Ocupação do Solo e ao Código de Edificações (SÃO PAULO, 1997).

${ }^{75}$ É interessante notar que esta referência a um projeto de Cidade Mundial surge no discurso do poder público simultaneamente à sua adoção no discurso da Associação Viva o Centro, como pode ser constado a partir da análise do documento intitulado "Associação Viva o Centro: propostas e compromissos" (ASSOCIAÇÃO VIVA O CENTRO, 1996).
} 
mecanismo pelo qual se tornaria possível colocar São Paulo no mapa das economias mundiais. Isso porque a partir da Operação se promoveria: a atração de novos investimentos (nacionais e transnacionais) e de novos negócios para esta região e o desenvolvimento de sua potencialidade turística - entendida como promoção de novas funções para os edifícios históricos e de novos usos para o espaço público. Este processo não se daria, porém, sem antes eliminar os chamados "usos perdulários" que contribuiriam para a desvalorização desse espaço, tais como, a atividade dos comerciantes ambulantes, a presença de moradias subnormais (cortiços), a existência de moradores de rua, etc.

Em acréscimo ao que fôra proposto pela Operação Urbana Anhangabaú, a Operação Urbana Centro instituiu a chamada “Área de Especial Interesse”, onde os pedidos de elevação do potencial construtivo seriam concedidos gratuitamente durante os três primeiros anos de vigência desta Operação. Tal como ilustra a FIGURA 5 esta “Área de Especial Interesse" corresponde ao núcleo do Centro Histórico de São Paulo onde estão localizados os edifícios que compõem o patrimônio histórico da cidade, a maior parte das sedes dos bancos e demais empresas que atuam na região.

O que parece estar em questão é implantar em São Paulo uma gestão empresarial da cidade, na qual a produção do espaço deve ter como finalidade inequívoca a geração de lucro ou rentabilidade às partes envolvidas. Esta idéia aparece explícita no Programa de Valorização do Centro - PROCENTRO ${ }^{76}$. Por meio da análise dos documentos do poder público, constatou-se a persistência da idéia de que a realização de um projeto de revalorização do Centro Histórico de São Paulo depende da formação de parcerias com a iniciativa privada.

O PROCENTRO vem buscando soluções participativas que permitam o efetivo engajamento da iniciativa privada, ordenando investimentos voltados aos segmentos imobiliários para novas construções/incorporações ou para instalação de atividades produtivas terciárias, geradoras de emprego e renda (SÃO PAULO, 1998, p. 15).

Contudo, o que a ideologia em questão não esclarece é que esta estratégia faz da cidade uma mercadoria a ser negociada com as instituições privadas (mercado imobiliário e demais setores produtivos), passando negá-la como espaço de apropriação

\footnotetext{
${ }^{76}$ A partir da gestão Celso Pitta, o antigo Programa de Requalificação Urbana e Funcional do Centro de São Paulo, o PROCENTRO, passa a se chamar Programa de Valorização do Centro.
} 


\section{Figura 5: Área de Especial Interesse da Operação Urbana Centro}

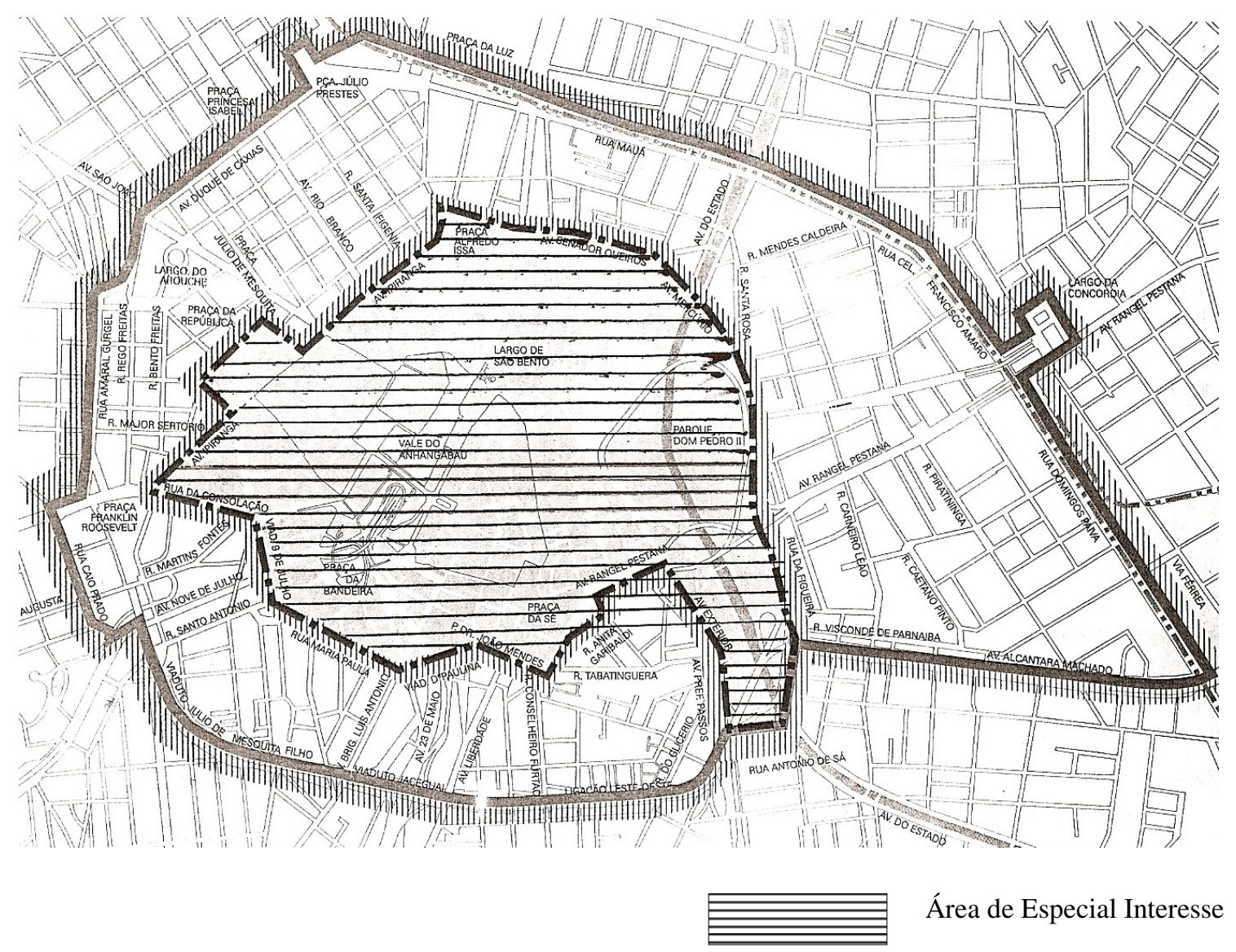

Fonte: (SÃO PAULO, 1997) 
do restante da sociedade. Isso porque o uso que os cidadãos fazem deste espaço não é considerado produtivo ${ }^{77}$.

É neste sentido que se pode compreender um discurso que afirma ser necessário estabelecer uma nova vocação econômica para o Centro, modificando o seu uso em nome do desenvolvimento de um suposto potencial turístico e cultural. Tais modificações seriam capazes de propiciar um melhor aproveitamento desse espaço ${ }^{78}$, da mesma maneira que poderiam atrair um público "mais exigente em termos de infraestrutura e equipamentos/mobiliários urbanos", ou ainda "um público alvo acostumado a eventos culturais e exposições de alto nível" (SÃO PAULO, 1988, p. 10 e 29). Neste caso, entenda-se por público exigente: artistas, intelectuais, estudantes universitários, turistas. Ou seja, um novo contingente populacional com perfil social e econômico distinto das classes mais populares.

No tocante à revalorização do Centro Histórico de São Paulo, tal como sugeria o PROCENTRO, o caminho para alcançar este intento passava, primeiramente, pela solução dos problemas ocasionados pela existência de cortiços na região central (SOUZA, 1998). Uma vez que a este tipo de moradia era atribuída a responsabilidade pela degradação do local, assim como pela queda dos preços dos imóveis da região.

Foi partindo da perspectiva de que os cortiços representam um entrave à revalorização do Centro Histórico de São Paulo que o poder público propôs um plano de intervenções nas áreas encortiçadas. Sendo assim, o que estava em questão não era intervir nos cortiços para promover a melhoria das condições de vida da população que o habitava; mas sim, a eliminação desse "obstáculo" para a efetiva revalorização do espaço.

O plano de intervenções sugerido para as áreas encortiçadas do Centro de São Paulo está contido no documento "Propostas para Habitação na área Central", que previa a "recuperação de áreas degradadas e encortiçadas com a construção de novas edificações em terrenos subutilizados e reforma de edificações vazias" (DIOGO, 2004, p. 65). Entretanto, ao mesmo tempo em que encaminhava propostas para atender as

\footnotetext{
${ }^{77}$ Segundo Carlos, por uso produtivo do espaço, pode-se entender: "a cidade produzida dentro dos estritos limites da produção econômica, enquanto condição da produção/reprodução do capital..." já o uso improdutivo do espaço estaria "centrado na vida cotidiana" (CARLOS, 2003, s.p.).

${ }^{78}$ Como recurso para realização desses intentos, a prefeitura contava, principalmente, com a possibilidade de serem aprovados acordos de financiamento com o Banco Interamericano de Desenvolvimento - BID, da ordem de U\$ 200 milhões, dos quais 50\% seria a contrapartida do poder público municipal. Porém, apenas na gestão de Marta Suplicy este acordo foi concretizado, havendo um empréstimo de US\$ 100 milhões do BID e contrapartida de US\$ 67 milhões do poder público municipal.
} 
necessidades dos moradores de cortiços, este mesmo plano sugeria a promoção de habitações para as camadas da classe média. Assim, tal como o discurso quer fazer acreditar, indivíduos cujos perfis sócio-econômicos se diferenciam poderiam "compartilhar" dos benefícios de morar no Centro Histórico de São Paulo. Em grande parte, tais propostas convergiam com os ideais defendidos pela Associação Viva o Centro, como pode ser apreendido na fala de Meyer “... o Centro poderá ser um bairro popular, não de pobre, mas popular...” (MEYER apud FRÚGOLI, 2000, p. 85).

De acordo com Denise Souza ${ }^{79}$ (1998), entidades não governamentais e movimentos sociais como, a União dos Movimentos de Moradia (UMM), a Unificação das Lutas de Cortiços (ULC), o Fórum dos Cortiços, os Sem-Teto de São Paulo e a Pastoral da Terra, foram chamados a discutir com o poder público soluções para o problema da moradia na área central de São Paulo. Houve, portanto, nessa gestão um esforço para promover uma abertura às reivindicações populares. Contudo, deve-se relativizar esta abertura ou diálogo, tendo em vista que, à exceção da situação acima exposta, aquilo que a gestão Celso Pitta procurou classificar como participação popular $^{80}$ se trata, na verdade, de um grupo de moradores ou de seus representantes filiados à Associação Viva o Centro e organizados em torno das chamadas Ações Locais. Nesse sentido, elabora-se a seguinte questão: em que medida uma participação mediada por interesses de setores privados pode ser considerada como participação popular?

Embora o questionamento acima não se enquadre de modo específico ao conjunto de questões ao qual esta pesquisa pretende responder, não foi possível declinar à inevitabilidade de propô-lo. Todavia, por acreditar que a resposta a esta pergunta suscita novas reflexões e análises mais complexas, optou-se por deixá-la em aberto. Para esta pesquisa é mais significativo investigar os elementos que conduziram a este questionamento, na medida em que revelaram mais uma vez a permeabilidade do poder público aos interesses da iniciativa privada. Esta "parceria" entre o poder público e a iniciativa privada, como já afirmado em outras oportunidades, passa a ser a substância para as atuais transformações do espaço urbano, de maneira que perpassa (com

\footnotetext{
${ }^{79}$ Assessora da Secretaria da Habitação e Desenvolvimento Urbano do Município de São Paulo.

80 Segundo Denise Souza, "dentro do programa PROCENTRO, a participação da população, especialmente no Centro, se tornou mais efetiva com a criação, por parte da Associação Viva o Centro [...] de sub-programa denominado Ações Locais, um projeto típico de zeladoria urbana, presente em 26 áreas da região central, onde pessoas e entidades interessadas trabalham para conseguir a melhoria e manutenção destes locais" (SOUZA, 1998, p. 76)
} 
diferentes intensidades) as políticas urbanas das sucessivas gestões municipais da cidade de São Paulo.

\subsection{Gestão Marta Suplicy - Partido dos Trabalhadores (2001-2004)}

Dentre as diferentes gestões até aqui analisadas, foi na gestão Marta Suplicy que o processo de revalorização do Centro Histórico de São Paulo teve marcadamente um enfoque voltado para o reforço da função habitacional dessa região..

Durante este governo o poder público passou a divulgar as "condições vantajosas" de morar no Centro. Como foi exposto no documento "Morar, viver e trabalhar no centro... Agora é possível" (SÃO PAULO, 2002a), estas vantagens estariam associadas à infra-estrutura já consolidada na região, composta por uma rede de serviços urbanos, oportunidades de trabalho, cultura e lazer; bem como pela existência de programas habitacionais. Dentre tais programas encontra-se o Programa de Arrendamento Residencial (PAR) que, custeado pela Caixa Econômica Federal (CEF), tem como objetivo financiar habitação no Centro da cidade para famílias com renda de até seis salários mínimos.

Por considerar que o Centro é um espaço onde podem ser presenciadas situações contrastantes - por um lado apresenta extrema acessibilidade e um amplo estoque imobiliário, por outro lado, boa parte deste imobiliário está subutilizado e um número considerável de indivíduos vivem em habitações precárias -, o poder público elaborou um programa para revalorização desta região, mas que procurava promover a inclusão social dos indivíduos alijados do uso e da apropriação deste espaço. Nesse sentido, foi elaborado pela gestão Marta Suplicy o plano "Reconstruir o Centro", que tinha como objetivos:

Resgatar o caráter público do espaço público; ampliar o uso residencial e garantir a diversidade de funções; consolidar a identidade de centro metropolitano; criar mecanismos de gestão democrática voltados para o interesse coletivo; e atuar sistematicamente para a redução de violência (SÃO PAULO, 2001, p. 20, grifos nossos).

Tal como descrito no Programa, a concretização destes objetivos se daria por meio da efetivação de oito subprogramas, chamados: "Andar no Centro"; "Morar no Centro"; "Trabalhar no Centro"; "Descobrir o Centro"; "Preservar o Centro"; "Investir no Centro"; "Cuidar do Centro"; e "Governar o Centro". 
No que concerne ao subprograma "Morar no Centro", os objetivos delimitados visavam "contribuir para o repovoamento da área central; viabilizar moradia para a população de baixa renda na área central; reabilitar edifícios desocupados para uso habitacional; melhorar a qualidade de vida dos habitantes da área central" (SÃO PAULO, 2001, p. 27).

É importante ressaltar que, ao menos enquanto proposta formal, o plano "Reconstruir o Centro" delimitava estratégias que visavam contribuir para a permanência da população de menor rendimento no Centro da cidade de São Paulo. No entanto, o poder público não esclarecia os seguintes aspectos: quais seriam os recursos que tornariam viáveis os objetivos traçados; a quem o plano denominava por "população de baixa renda" e de que modo se daria o acesso desta população ao programa?

Um maior detalhamento à proposta de moradia no Centro de São Paulo foi dado quando da elaboração, pelo poder público - já ao final da gestão Marta Suplicy -, de um programa que contemplava com maior especificidade esta questão, o "Programa Morar no Centro" (SÃO PAULO, 2004c). Os principais objetivos deste Programa eram: "melhorar as condições da habitação de quem já vive no centro, promover a inclusão social da população de baixa renda e atrair novos moradores para a região" (SÃO PAULO, 2004c, p. 1). E os princípios básicos previam:

[...] articular a política habitacional com o conjunto de intervenções, públicas e privadas, voltadas à reabilitação da região central e ao seu repovoamento [como forma de] garantir que pessoas que hoje moram e trabalham no centro possam ser beneficiadas pelo processo, mediante programas que garantam a sua permanência (SÃO PAULO, 2004c, p. 2).

Com vistas a promover a permanência da população de baixo rendimento no Centro Histórico de São Paulo, o poder público desenvolveu diferentes "modalidades de atendimento habitacional", como: o Programa de "Locação Social” - com subsídio à locação de unidades habitacionais por famílias com renda mensal de até três salários mínimos e, por isso, impossibilitadas de fazer aquisição de um imóvel; o "Programa de Arrendamento Residencial” (PAR) ${ }^{81}$ - que "constitui a primeira (e única) linha de financiamento para Habitação de Interesse Social a contemplar a possibilidade de recuperação e reforma de edifícios existentes" (MALERONKA, 2005, p. 6); o Programa

\footnotetext{
${ }^{81}$ O PAR foi criado pelo governo federal a partir de medida provisória no ano de 1999, e se tornou Lei Federal no ano de 2001.
} 
"Bolsa Aluguel" - que permitiu a concessão subsídios financeiros à famílias com renda entre um e dez salários mínimos, como forma de complementar o valor do aluguel em imóveis do mercado privado; o "Programa de Intervenção em Cortiços" - que visava promover a melhoraria das condições habitacionais dos cortiços por meio de intervenções urbanísticas (SÃO PAULO, 2004c).

No caso específico do Programa de Arrendamento Residencial (PAR) ${ }^{82}$, tinha-se como proposta propiciar o acesso à moradia para a população de baixa renda mediante o arrendamento do imóvel no Centro da cidade (após seleção dos arrendatários conforme critério de capacidade de pagamento), dando ao morador a opção de compra desse bem após quinze anos de pagamento ininterrupto. Neste caso, sendo abatido do valor da dívida os valores pagos durante o período (SÃO PAULO, 2002b).

Tal como afirmava o poder público, tanto o PAR como as demais modalidades de atendimento habitacional tinham como finalidade criar uma perspectiva de permanência das classes de baixo poder aquisitivo (mas necessariamente com algum poder aquisitivo) no Centro de São Paulo, reconhecendo para isso que, em vista dos investimentos efetuados na revalorização desta região - e como resultado da sua conseqüente valorização imobiliária - poderia haver a expulsão dessa população para outras áreas da cidade. Deste modo, o poder público parecia admitir que a criação de programas habitacionais para as camadas populares no Centro Histórico da cidade era uma tentativa de amenizar um processo, inexoravelmente, gerador de segregação sócioespacial, mas com o qual ele não podia - ou não queria - romper.

Diante do que até aqui foi exposto, poder-se-ia conduzir uma análise que destacasse os méritos das propostas apresentadas pela gestão Marta Suplicy para a revalorização do Centro de São Paulo, principalmente, no que diz respeito à (hipotética) tentativa de inverter um ideal de intervenção urbana que, ao menos nas gestões Paulo Maluf (1993-1996) e Celso Pitta (1997-2000), promovia a valorização imobiliária da região central em detrimento da apropriação do espaço pelas classes de menor rendimento da sociedade. Contudo, no tocante a uma análise que pretenda transcender o campo das propostas formais ou dos discursos e tenta avaliar os resultados das

\footnotetext{
${ }^{82}$ O programa foi instituído em São Paulo no ano de 2001, por meio de um convênio entre a Caixa Econômica Federal e a Prefeitura deste município. Ficou acordado que, à Caixa caberia a avaliação do projeto, a aquisição do imóvel, a contratação da obra e a seleção dos arrendatários. Já a Prefeitura ficava encarregada de identificar a demanda e criar formas de agilizar a aprovação dos projetos habitacionais, o que envolveria a revisão da legislação de habitação de interesse social e da lei de zoneamento (SÃO PAULO, 2002b, p. 12).
} 
estratégias postas em prática, deve-se relativizar os feitos obtidos pelas propostas apresentadas pelo poder público, na administração Marta Suplicy, frente ao aproveitamento dos edifícios vazios ou subutilizados para a promoção de habitação de interesse social no Centro de São Paulo.

No caso da viabilização de unidades habitacionais por meio do PAR, por meio da reforma de edifícios vazios ou subutilizados localizados no Centro de São Paulo (PARReforma), é necessário fazer algumas considerações. A primeira delas diz respeito à própria estrutura deste programa que, ao mesmo tempo em que tinha como premissa se constituir no âmbito de um projeto de cunho social, também possibilitava às construtoras e proprietários de imóveis a aquisição de financiamento da Caixa Econômica para reforma e/ou readequação de edifícios ociosos e produção habitação social. Portanto, garantia aos agentes imobiliários formas irrestritas de fomentar (e valorizar) os seus negócios no Centro da cidade. Neste caso, os recursos ${ }^{83}$ da Caixa passavam a financiar diretamente o investidor privado e não prioritariamente o morador do edifício. Deve-se observar ainda que, ao ser aprovado o projeto da construtora, a Caixa faria o pagamento à vista do valor da área e executaria o pagamento, em parcelas, do valor da obra.

De acordo com Maleronka (2005), após intensa negociação dos movimentos sociais com o governo federal foi aberto um precedente para que estes agentes pudessem promover, de modo autônomo (sem a intermediação dos construtores nesta negociação), a produção de habitação social no Centro de São Paulo utilizando os recursos do PAR-Reforma. Este acordo foi firmado no ano de 1999 e permitiu aos movimentos populares realizar (entre os anos de 1999 e 2003) a reabilitação de cinco edifícios na região, foram eles: Rizkallah Jorge (167 Unidades Habitacionais), Fernão Sales (54 UHs), Olga Benário Prestes (84 UHs), Maria Paula (75 UHs), e o edifício Labor (84 UHs) ${ }^{84}$ (MALERONKA, 2005).

Portanto, a realização desta empreitada foi resultado direto das lutas travadas pelos movimentos sociais de moradia com o governo federal, sem que houvesse, ao longo do processo, uma interferência direta da administração pública municipal. Porém, as 464 unidades habitacionais produzidas por meio do PAR-Reforma entraram cômputo

\footnotetext{
${ }^{83}$ A Lei Federal 10.188/2001 criou o Fundo de Arrendamento Residencial (FAR), cujos recursos são utilizados pelo PAR. Por sua vez, o FAR é composto pelo Fundo de Desenvolvimento Social (FDS); Fundo de Investimento Social (FINSOCIAL) e Fundo de Apoio ao Desenvolvimento Social (FAZ).

${ }^{84}$ Ressalve-se que à exceção do edifício Olga Benário Prestes, localizado no distrito Brás, todos os demais se localizam no Centro Histórico de São Paulo (distritos Sé e República).
} 
geral dos projetos habitacionais efetivados pela Prefeitura Municipal no período de 2001 a 2004, tal como consta no "Balanço Qualitativo de Gestão 2001-2004" (SÃO PAULO, 2004a).

Deve-se considerar que na gestão Marta Suplicy havia em execução (ou em fase de negociação) a reabilitação, por meio do PAR, de cinco edifícios localizados no Centro de São Paulo (o que representaria 1059 Unidades Habitacionais). Se forem contrapostas as iniciativas levadas a cabo ao número de imóveis desocupados no Centro da cidade se constataria que muita coisa ainda teria ser feita para um maior enfrentamento do problema habitacional existente em São Paulo. De acordo com Maleronka,

Em São Paulo, apesar do contexto aparentemente favorável para a implementação da modalidade Reforma do PAR - existência de um estoque considerável de edifícios vazios ou semi-ocupados e uma política municipal direcionada à recuperação do centro da cidade foram viabilizados apenas cinco empreendimentos PAR-Reforma. A maior parte dos recursos do PAR continua produzindo conjuntos habitacionais na periferia da cidade. (MALERONKA, 2004, p. XII).

Desta forma, dá-se continuidade a uma política que perpetua a periferia como lugar de habitação da população de menor renda. Sendo assim, é necessário relativizar os efeitos sociais produzidos pelos programas efetivados na gestão Marta Suplicy. Contudo, não se pode deixar de reconhecer que houve neste governo consideráveis avanços políticos e sociais se comparado às gestões que a antecederam.

No que diz respeito à permanência da população de menor rendimento no Centro Histórico de São Paulo, a possibilidade de torná-la factível ocorreu com a aprovação do Plano Diretor Estratégico municipal, que institui as chamadas Zonas Especiais de Interesse Social (ZEIS).

As Zonas Especiais de Interesse Social são destinadas prioritariamente, à recuperação urbanística, à regularização fundiária e à produção de Habitações de Interesse Social - HISs ou de Mercado Popular - HMPs, [...] inclusive à recuperação de imóveis degradados e à provisão de equipamentos sociais e culturais, espaços públicos, serviços e comércio de caráter local (SÃO PAULO, 2004b, p. 34).

Houve na gestão Marta Suplicy - não sem o devido empenho e pressão dos movimentos sociais - o esforço para a aprovação e, conseqüente, delimitação das ZEIS na região central de São Paulo. Tal fato representou a possibilidade de dar um novo rumo à dinâmica de produção do espaço no Centro Histórico à medida que, ao menos 
em termos formais, abria um horizonte para a realização da função social da propriedade em imóveis/áreas, até então, subutilizados ou ociosos.

Contudo, a maior parte das Zonas Especiais de Interesse Social que foram aprovadas pelo Plano Diretor está localizada nas adjacências do Centro Histórico FIGURA 6. Este fato permite supor que se optou por efetivar habitações de interesse social em áreas onde o preço do solo é mais baixo ${ }^{85}$ e onde os interesses do mercado e dos proprietários imobiliários (pró-revalorização do Centro) não se fazem tão presentes. Todavia, esta opção entra em contradição com as demandas dos movimentos de moradia, que indicam a delimitação de algumas ZEIS no limite interno da centralidade histórica. Essa indicação se justificaria em vista da existência de inúmeros imóveis vazios nesta região e da sua farta infra-estrutura urbana.

As constatações acima realizadas permitem pressupor que a presença ou a permanência da população de baixa renda é aceita no Centro $^{86}$ da cidade, porém não no pedaço que interessa aos agentes hegemônicos da sociedade, para os quais, em geral, a habitação popular está associada à desvalorização do espaço.

Embora os instrumentos urbanísticos regulamentados no Plano Diretor sinalizem a construção de novos ideais para se pensar a respeito da produção de cidades mais justas e democráticas (ROLNIK, 2001), vê-se, a exemplo da contradição existente em torno da instituição das Zonas Especiais de Interesse Social no Centro de São Paulo, que estes ideais parecem sucumbir à imposição de determinados interesses que já estão arraigados na cidade e que tentam fazer dela o seu espaço de dominação.

Dentre os estímulos dados pelo poder público ao processo de revalorização do Centro Histórico de São Paulo na gestão Marta Suplicy, pode-se citar - além, da Operação Urbana Centro, das intervenções paisagísticas e de reforço da segurança na região -, a transferência da sede da Prefeitura do Município de São Paulo do Parque D. Pedro II para o Edifício Conde Francisco Matarazzo, popularmente conhecido como Banespinha, localizado nas proximidades da Praça do Patriarca e do Vale do Anhangabaú.

A mudança da sede da Prefeitura Municipal (no ano de 2004) realizou-se como continuidade de uma política de transferência dos órgãos do poder público para o eixo de revalorização do Centro Histórico de São Paulo iniciado na gestão Luiza Erundina

\footnotetext{
${ }^{85}$ A justificativa do poder público é de que os preços mais baixos do solo podem refletir sobre o custo final deste projeto de modo a torná-lo ainda mais viável à população de baixa renda.

${ }^{86}$ Neste caso, entende-se por Centro todos os distritos que compõe a Subprefeitura Sé.
} 
Figura 6: Zeis aprovadas no PDEM, em estudo na SEHAB e sugeridas pelos moradores e movimentos de moradia da subprefeitura Sé.

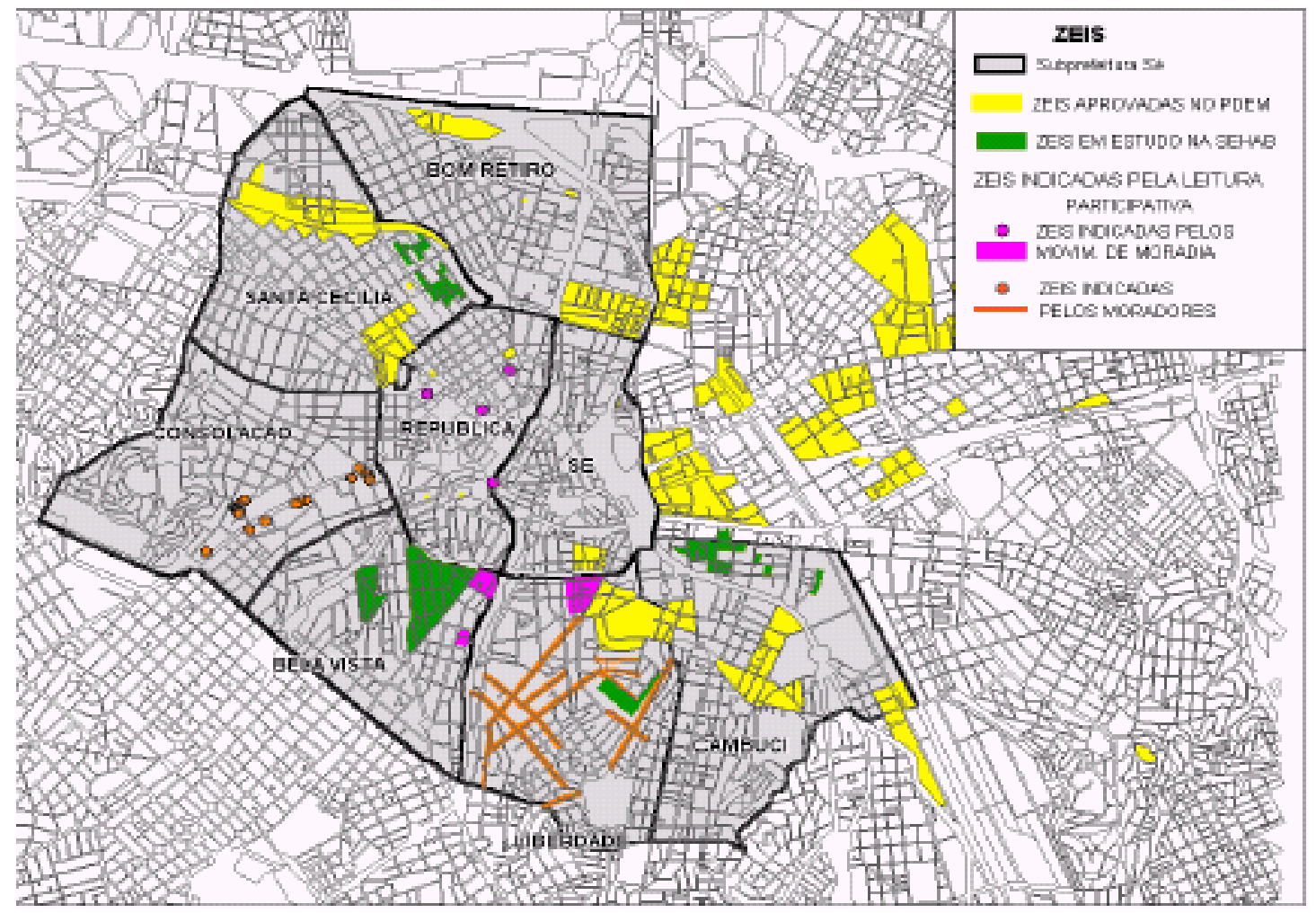

Fonte: (São Paulo, 2003) 
(1989-1992), ao mesmo tempo em que, coincidentemente ou não, contemplava uma das diretrizes do plano de revalorização amparado pela Associação Viva o Centro que defendia - e ainda hoje defende - o necessário retorno do poder público para o Centro Histórico de São Paulo como forma de transmitir credibilidade às estratégias que procuram promover a região central de São Paulo.

Ainda no que concerne à revalorização do Centro Histórico de São Paulo, como já foi possível analisar, o PROCENTRO se constituiu nas gestões Maluf e Pitta como o principal órgão do poder público a impulsionar estratégias de intervenção urbanística e de transformação do uso da região central da cidade. Na gestão Marta, o PROCENTRO passou a se chamar "Programa de Reabilitação da Área Central - Ação Centro", mantendo as suas antigas atribuições e incorporando - ao menos, enquanto proposta formal - novas metas, dentre as quais: promover a inclusão social e a reversão do esvaziamento residencial do Centro.

Foi no contexto da Ação Centro que foi firmado um acordo entre a Prefeitura de São Paulo e o Banco Interamericano de Desenvolvimento (BID) ${ }^{87}$, prevendo um empréstimo de US\$100 milhões vinculado a uma contrapartida da Prefeitura de US\$ 67 milhões a serem empregados na: "reversão da desvalorização imobiliária e recuperação da função residencial; transformação do perfil econômico e social do centro; recuperação do ambiente urbano; fortalecimento institucional do município" (SÃO PAULO, 2004d, s.p.).

Nesta ocasião, o discurso do poder público passa a sugerir que "a Prefeitura de São Paulo [está] trabalhando para que o Centro seja mais democrático, tenha sua diversidade respeitada e venha ser um espaço com justiça social" (SÃO PAULO, 2004d, s.p.). Entretanto, somente a quarta parte dos recursos que se pretendia destinar para promover o "Programa de Reabilitação da Área Central/BID” seria aplicada diretamente no desenvolvimento social da região: Programa Morar no Centro - US\$ 25 milhões; Regularização do comércio informal e atenção aos grupos vulneráveis - US\$ 3 milhões; Atenção a grupos vulneráveis - U\$ 13 milhões ${ }^{88}$. A parcela restante pretendia ser utilizada em obras de infra-estrutura, recuperação e refuncionalização de edifícios históricos e demais obras de melhoramento estético-paisagístico.

\footnotetext{
${ }^{87}$ Deve-se relembrar que este acordo entre poder público e BID foi negociado já na gestão Celso Pitta.

${ }^{88}$ Todos esses valores foram aproximados.
} 
Portanto, embora seja evidente uma preocupação do poder público com a questão das classes menos favorecidas - ao criar estímulos para a sua permanência na região Central - tais estratégias ainda se apresentavam relativamente tímidas, frente ao projeto de produção do Centro Histórico como área para o consumo turístico e cultural. Este último projeto parece se firmar cada vez mais como uma estratégia que não se pode, ou não se quer, contrariar.

\subsection{Gestão José Serra ${ }^{89}$ e Gilberto Kassab - Partido da Social Democracia Brasileira/ Democratas (2005-2008)}

No discurso elaborado pela gestão José Serra para o Centro Histórico de São Paulo, considera-se o processo de revalorização deste espaço um elemento fundamental ao desenvolvimento da metrópole paulistana. Isso porque, a revalorização da área central é vista como uma das diretrizes capazes de contribuir favoravelmente para consolidá-la em uma cidade mundial, de modo a torná-la cada vez mais atrativa aos investimentos do capital, preferencialmente, os de origem internacional.

Da maneira como é encarada, a revalorização do Centro Histórico de São Paulo poderia atribuir um novo dinamismo a esta área e integrá-la ao conjunto de espaços que, em função da sua rede de serviços, infra-estrutura e lazeres permitem às empresas exercerem com eficiência as suas atividades produtivas - seja no âmbito nacional ou internacional. Isso asseguraria à metrópole de São Paulo uma maior visibilidade no cenário econômico mundial e tornando-a atrativa aos ansiados investimentos dos chamados agentes econômicos transnacionais.

O conjunto destas idéias está contido no Plano Plurianual (PPA) da cidade de São Paulo (DIÁRIO OFICIAL, 2005) elaborado pela gestão Serra/Kassab no ano de 2005. O PPA estabelece as metas e diretrizes a serem cumpridas pelo poder público municipal nas diferentes esferas da administração, entre os anos de 2006 e 2009.

Tal como apresenta o Plano Plurianual, a consolidação de São Paulo no status de Cidade Mundial depende da sua capacidade de reunir atributos que assegurem a sua inserção no contexto de uma economia mundializada. Esses atributos são:

... [criar] uma eficiente rede de telefonia de fibras óticas; centros de excelência em tratamentos de saúde [...], centros de pesquisa científica de ponta, além de atrativos culturais como um rico museu e uma

\footnotetext{
${ }^{89}$ Como já foi dito anteriormente, José Serra se elegeu prefeito de São Paulo em 2004 e passou o seu cargo para Gilberto Kassab em 2006, tendo em vista que foi eleito para o cargo de Governador do Estado de São Paulo em 2005.
} 
orquestra sinfônica de nível internacional. Também é fundamental criar condições para enfrentar as questões ambientais decorrentes da ocupação ilegal dos mananciais, encaminhar e resolver questões relacionadas aos moradores de rua, aos cortiços, à criação de espaços públicos adequados... (DIÁRIO OFICIAL, 2005, p 183).

Deve-se observar que são poucos os espaços da cidade que podem atender aos pré-requisitos acima traçados. Como faz entender o discurso oficial, o Centro Histórico de São Paulo foi "eleito" como o lugar profícuo para a integração da metrópole à rede de cidades mundiais. Contudo, o cumprimento destas intenções esbarra no processo de degradação em curso nesta região, de modo que, torna-se inevitável a sua revalorização. Neste exato momento, a retórica passa a dar legitimidade às transformações e intervenções urbanísticas a serem promovidas no Centro Histórico da cidade. Estas transformações - muito além de promoverem uma nova valorização do patrimônio local e implantarem as infra-estruturas necessárias à reprodução do capital - interferem no uso e apropriação do espaço por parcelas da população que têm o Centro da cidade como lugar de reprodução da vida.

É como parte das estratégias traçadas pelo poder público para promover a revalorização do Centro Histórico, que podem ser compreendidas as "Dez Idéias" para "resgatar a importância e o glamour do coração da cidade". As "Dez Idéias" foram apresentadas no ano de 2005, pelo então Subprefeito da Sé, Andrea Matarazzo ${ }^{90}$. Tais idéias visam:

[...] promover o fim dos calçadões; realizar melhorias no sistema de segurança da região; criar um novo centro comercial (lojas e escritórios) em terrenos públicos subtilizados; retirar de cena carroceiros e mendigos; promover um banho de limpeza em todo o centro (otimizar o corte de grama e as operações tapa-buracos); criar shopping centers para os camelôs; estabelecer parceria com empresas privadas para ações de zeladoria urbana; construir garagens subterrâneas; proibir a colocação de anúncios e distribuição de panfletos no centro; viabilizar a construção de uma universidade na 'Cracolândia'(VEJA SÃO PAULO, 2005, 12-20) ${ }^{91}$.

Grande parte das "Dez Idéias" apresentadas pelo subprefeito da Sé coincide com as "dez propostas" elaboradas pela Associação Viva o Centro (ASSOCIAÇÃO VIVA O CENTRO, 2004) e por ela encaminhada aos candidatos à Prefeitura do Município nas

\footnotetext{
90 Atualmente Andrea Matarazzo ocupa o cargo de Coordenação das Subprefeituras da Prefeitura da Cidade de São Paulo.

${ }^{91}$ Localizada no bairro da Santa Ifigênia (Distrito República), a "Cracolândia" refere-se ao quadrilátero formado pelas avenidas Rio Branco, Ipiranga, Cásper Líbero e rua Mauá. Nesta região há uma grande incidência de prostituição, tráfico e consumo de drogas.
} 
eleições do ano de 2004. Os elementos comuns entre as "idéias" e as "propostas" são: a extinção do sistema de calçadões; a construção de garagens subterrâneas; a criação de espaços adequados ao comércio informal; a implantação de um sistema de zeladoria urbana, segurança e fiscalização e a requalificação da região da Cracolândia. Estes fatos podem apontar para duas considerações. A primeira é a inexistência de um projeto original do poder público para o Centro Histórico; já a segunda, é a presteza da administração municipal em atender as demandas da iniciativa privada, tornando as políticas públicas ajustáveis aos interesses dos agentes privados.

Nota-se que as "dez idéias" propostas pelo poder público têm como fundamento promover um reordenamento do espaço por meio da realização de obras viárias; da melhoraria da circulação dos veículos; da extinção dos calçadões e dos carroceiros; da criação de novos espaços para o consumo (centros comerciais e shopping centers); e do embelezamento paisagístico, com controle da poluição visual e assepsia do espaço público. As "dez idéias" também objetivam promover uma nova ordem social, na qual não haverá mais espaço a ser apropriado pelo mendigo ${ }^{92}$; o ambulante deixará de interromper o passo do pedestre - que estará confinado em estreitas calçadas; as calçadas serão ocupadas pelos universitários da classe média paulistana, em substituição aos "meliantes" da Cracolândia, cuja atividade transgressora não mais será aceita ${ }^{93}$. A própria Cracolândia não será mais tolerada e desaparecerá para dar lugar à "Nova Luz" "94, este sim, um espaço público adequado.

Por intermédio de Andrea Matarazzo ${ }^{95}$, o poder público manifestou por diversas ocasiões que o seu objetivo, ao intervir no bairro da Santa Ifigênia, não é elitizá-lo, mas sim "estimular a sua multifuncionalidade e produzir uma diversidade social" na região. E isso só seria possível por meio da atração de população e de novos moradores. O

\footnotetext{
${ }^{92}$ Neste caso, não se objetiva eliminar a pobreza, mas apenas retira-la do campo de visão da elite.

${ }^{93}$ Conforme veiculado pela Folha de São Paulo, a partir da matéria intitulada "Ações tentam tirar região da ilegalidade", a Prefeitura e as polícias Civil, Militar e Federal realizaram "em março passado [de 2005] uma ofensiva com 220 policiais, batizada de Operação Limpa [que] abordou 740 pessoas. Cinco foram detidas em flagrante por porte de drogas e 111 seriam investigadas por suspeita de ligação com diversos crimes. Pelo menos 70 estrangeiros foram detidos pela PF, a maioria liberada depois. [...] Uma nova blitz no centro foi realizada cerca de um mês depois, sob o nome Revitalização da Luz, no final de abril. Outras dez pessoas foram presas e sete hotéis foram interditados [...]. Bares, ferros-velhos, empresas de turismo, cinemas-pornôs e até uma fábrica de pamonha foram interditadas naquela ocasião e em outras ações" (FOLHA DE SÃO PAULO, 2005, p. C1, grifo nosso).

${ }^{94}$ Após as devidas intervenções urbanísticas, a "Cracolândia" passará a ser conhecida por "Nova Luz".

${ }^{95}$ Estas idéias têm como referência a fala proferida por Andrea Matarazzo na palestra "A Revitalização do Centro de São Paulo" e no seminário "A Biblioteca e a Cidade: o entorno da Biblioteca", realizados, respectivamente, em 24/07/06 e 30/10/2006.
} 
discurso em questão afirma que "não se pode criar guetos no Centro de São Paulo", de tal modo, declara que este espaço "não deve ser um lugar nem para os ricos, nem para os pobres". Como forma de tolher qualquer intenção dos movimentos de moradia da região central, Matarazzo manifesta: "O centro não será somente uma região de habitação para os pobres. Ele não será uma Cidade Tiradentes ${ }^{96}$ ".

Mais uma vez, torna-se evidente que os objetivos do poder público para com a transformação e revalorização do Centro de São Paulo não devem confluir com qualquer tipo de interesse manifestado pelas classes populares. Talvez, as idéias expressas por Matarazzo justifiquem o fechamento do poder público e de suas instâncias de participação social, como foi o caso do encerramento da Coordenação Executiva Provisória Ação Centro, na qual o Fórum Centro Vivo tinha assento.

$\mathrm{Na}$ atual administração há um temor de que a região central se configure como uma área eminentemente popular e que a presença dos pobres constitua um elemento de desestímulo aos novos usuários e consumidores, que se espera atrair para aquela região. Nesse sentido, será que o propalado estímulo à diversidade social tem sentido diverso de uma gentrification do Centro da Cidade?

A intervenção do poder público na Cracolândia ganhou um desfecho em setembro de 2006, quando, por meio da publicação de um decreto municipal, a Prefeitura de São Paulo declarou como sendo de utilidade pública uma área equivalente a 150 mil $\mathrm{m}^{2}$ nesta região - FIGURA 7. Tal decreto legalizou a desapropriação dos imóveis localizados neste trecho. Conforme consta em matéria publicada pela Folha de São Paulo:

A proposta da Prefeitura é transformar a região da Cracolândia em um pólo tecnológico, tendo como base o Porto digital criado em Recife (PE) [...]. Para atrair a iniciativa privada, a Prefeitura de São Paulo estuda a diminuição de ISS (Imposto Sobre Serviços) e de IPTU (Imposto Predial e Territorial Urbano) para quem se instalar na região (FOLHA DE SÃO PAULO, 2005, p. C1, grifo do autor).

A proposta de intervenção apresentada pelo poder público para a revalorização da Cracolândia vai ao encontro do discurso que sustenta a necessidade de se produzir espaços que contenham atributos capazes de assegurar a inserção da metrópole no contexto de uma economia mundializada. Um desses atributos seria a criação dos chamados "pólos tecnológicos". Ao mesmo tempo, esta proposta de intervenção reforça

\footnotetext{
${ }^{96}$ Cidade Tiradentes é um dos bairros localizados na periferia de São Paulo e se constituí como uma das áreas de maior pobreza da cidade, ao mesmo tempo em que concentra o maior volume de conjuntos habitacionais para população de baixo poder renda de todo o município.
} 
Figura 7: Cracolândia. Operação Limpa

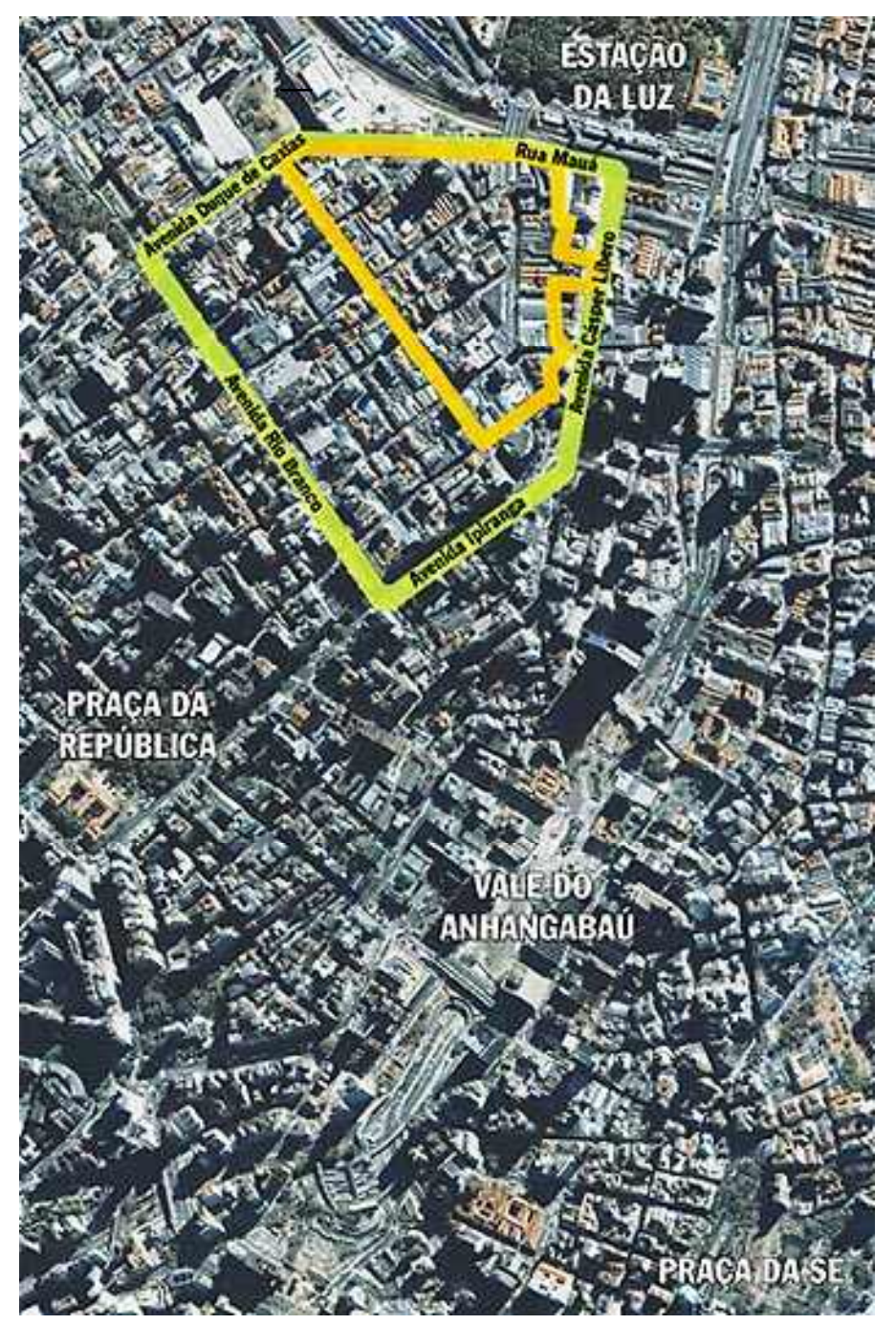

Área laranja - $150.000 \mathrm{~m}^{2}$ - a ser derrubada

Área verde $-250.000 m^{2}$ - a ser desapropriada

Fonte: (VEJA SÃO PAULO, 2006) 
a tendência à constituição de "parcerias" entre o poder público e a iniciativa privada, com o objetivo de promover a transformação de grandes áreas da cidade. O elemento que torna atrativo a consolidação desta parceria é a concessão de recursos públicos aos agentes privados. Conforme reconhece o poder público:

A recuperação da área central demanda iniciativas com a composição
de ações públicas e privadas de formas e naturezas diversas. O papel
dos investimentos públicos é sinalizar e articular uma nova realidade
para estimular os investimentos privados, minimizando seus riscos,
seja no que concerne aos empreendimentos imobiliários, seja no que
toca aos empreendimentos nos setores de comércio e serviços. Nesse
sentido, ressalta-se o papel do poder público em disponibilizar um
conjunto de instrumentos relativos ao planejamento urbano, e de ações
de requalificação do espaço, indispensáveis para gerar um clima de
confiança na recuperação de áreas degradadas, garantindo a
sustentabilidade dos investimentos realizados (DIÁRIO OFICIAL,
2005, p. 190).

Mais uma vez, é possível observar que o papel que o poder público relega a si próprio é o de se tornar mediador das relações que permitem à iniciativa privada se apropriar do espaço, e a partir dele reproduzir suas relações capitalistas de produção.

Na gestão José Serra, a estratégia para reforçar a função moradia no Centro Histórico de São Paulo também está baseada nesta "parceria" entre o poder público e a iniciativa privada e na isenção de impostos. Tal como consta no Plano Plurianual da cidade de São Paulo:

São grandes as disponibilidades de áreas e, sobretudo, edifícios desocupados na região central: prédios a serem reformados ou adaptados com mudança de uso, construções deterioradas que podem ser substituídas por edifícios residenciais, prédios com baixa densidade populacional, todos constituem possibilidades para $\mathrm{o}$ provimento de alternativas de moradia. A existência de mais de 40 mil unidades habitacionais vagas na região, sem levar em conta as moradias de uso ocasional, é fator importante na articulação dos programas de financiamento e ações com o mercado privado (DIÁRIO OFICIAL, 2005, p.196).

Note-se que neste trecho há referência direta às possibilidades que se abrem ao mercado privado para produzir habitação no Centro, tendo em vista a disponibilidade de espaços considerados ociosos ou subutilizados. Contudo, como argumentado ao longo deste trabalho, quando o mercado privado se torna o principal provedor ou financiador de habitação à população, as possibilidades de acesso à moradia passam a se restringir àqueles setores que dispõem de poder aquisitivo, ficando excluídas deste processo grandes parcelas empobrecidas da população paulistana, dentre elas, aquelas que demandam por moradia no Centro de São Paulo. 
A proposta de reforço da função habitacional do Centro Histórico apresentada pela gestão Serra/Kassab recuperava inicialmente itens que compunham o "Programa Morar no Centro" da gestão Marta Suplicy,-- onde estão inclusas a Atuação em Cortiços, a Locação Social/Bolsa aluguel e as Moradias Transitórias (DIÁRIO OFICIAL, 2005). Ou seja, recupera um conjunto de propostas que, ao menos no plano formal, poderiam propiciar formas de habitação para as pessoas de baixo rendimento, e possibilitar a sua permanência nesta região.

Todavia, a estratégia de maior relevo para enfatizar o Centro Histórico como um espaço de moradia é aquela que busca atrair uma população capaz de adquirir no mercado privado a sua parcela de espaço para habitação. Deve, portanto, dispor de poder aquisitivo para consumir os novos serviços que pretendem ser oferecidos na região, como bares, cafés, museus, universidades, entre outros.

Esta estratégia encontra respaldo no "Programa de Incentivo à Iniciativa Privada" (DIÁRIO OFICIAL, 2005) baseado na concessão de incentivos, pelo poder público, aos agentes privados - agentes do setor imobiliário e da construção civil visando à construção, reforma e requalificação de imóveis para setores de classe média e média baixa (no centro e no centro expandido). Isso seria possível por meio da "oferta pública de imóveis passíveis de serem enquadrados no programa [...], e financiamento para as obras e ao beneficiário garantidos, e com a demanda pré-selecionada, além de contar com as vantagens do Plano Diretor Integrado" (DIÁRIO OFICIAL, 2005, p. 197198).

No início de 2006, Geraldo Biasoto ${ }^{97}$ reafirmou essas condições quando anunciou as "novas" medidas a serem implantadas pelo poder público ao longo da gestão Serra/Kassab, dentre as quais estava: promover a reversão da desvalorização imobiliária do Centro Histórico da cidade, por meio de estímulos ao empreendedor privado para a realização de novas incorporações nesta região. Da mesma forma, ele evidenciou que este processo não se realizaria pela intervenção direta do poder público na compra de edifícios ociosos e produção de habitação de interesse social, mas sim pela operacionalização de uma parceria público privada entre o Estado - agente viabilizador de intervenções - e a iniciativa privada enquanto agente interventor ${ }^{98}$.

\footnotetext{
${ }^{97}$ Vice-presidente da Empresa Municipal de Urbanização (Emurb).

98 Anúncio realizado na palestra “A revitalização do Centro de São Paulo”, realizada em 24/07/2006.
} 
Às medidas acima enunciadas se somaram outras ações da Prefeitura municipal, que ao final do ano de 2006 promoveu o corte (não renovação dos contratos existentes) dos programas "Bolsa Aluguel" e "Locação Social". Esta situação propiciou recentemente uma série de manifestações organizadas pelos movimentos sociais, tornando pública a condição de dezenas de famílias que estão na iminência de ser desalojadas e reivindicando a retomada desses projetos.

De fato, como pronunciou o secretário da habitação da Prefeitura Municipal de São Paulo, Orlando de Almeida Filho: “[a Habitação no Centro Histórico] é prioridade para as classes média e alta, uma vez que esses segmentos consomem produtos e serviços, pagam tributos e geram empregos" ${ }^{99}$. Esta afirmação dá a real dimensão do público que se espera beneficiar com o processo de revalorização do Centro Histórico, e também a quem se espera atrair para concretizar o plano de reforço da função habitacional neste espaço.

\subsection{Delineando semelhanças e diferenças entre as gestões municipais}

Pelas análises realizadas é possível observar que a revalorização do Centro Histórico de São Paulo é um processo que perpassa as distintas gestões municipais. No entanto, no período analisado (1991-2006) seis prefeitos estiveram à frente do poder público municipal e imprimiram à suas administrações os princípios políticos com os quais pactuavam. Isso pode sugerir que, além de uma suposta vontade política em retomar o tema, o interesse por uma revalorização do Centro de São Paulo se mantém ativo, em função das demandas ou força dos agentes políticos (como, a Associação Viva o Centro) que exercem pressão para a manutenção deste tema na pauta do dia do poder público.

Ao longo dessas gestões constatou-se que, apesar de uma relativa especificidade no que diz respeito às estratégias de revalorização do Centro Histórico propostas em cada um dos períodos, determinados temas foram sempre privilegiados. Nesse sentido, a idéia de propiciar uma transformação espacial da região central a partir da mudança do seu uso foi reincidentemente veiculada. Os novos usos são tidos como suportes para valorização imobiliária do espaço e também transformam o Centro num espaço de consumo - cultural e turístico - da cidade. Esse ideário foi um elemento de

\footnotetext{
99 Fala proferida na palestra “Aula São Paulo - Desenvolvimento da Região Central da Cidade de São Paulo", realizado no dia 19/09/05.
} 
convergência ou consenso entre as diferentes gestões municipais. Do mesmo modo, havia a preocupação em promover o reforço habitacional da região, entretanto, esta questão ganhou diferentes enfoques.

Nas administrações de Luiza Erundina e Marta Suplicy - com maior ênfase para esta última - as políticas públicas giravam em torno da promoção de habitação de interesse social no centro. Desse modo, objetivavam um melhor aproveitamento do uso do espaço - dado elevado número de imóveis vagos - e contribuir para a permanência das classes populares do Centro. Nas demais gestões - respectivamente, Maluf, Pitta e Serra/Kassab - não houve a formulação de um plano específico para ocupação residencial do centro. Havia, contudo, um ideal de propiciar o reforço da função moradia na região, como elemento para atração de um novo contingente populacional. Conforme o discurso evidenciava, essa nova população estaria apta a fazer um uso qualificado do espaço, contribuindo positivamente para a sua revalorização. Esta mesma ideologia era aquela que procurava imputar às classes populares o ônus pela deterioração do espaço.

Uma assimetria entre as distintas administrações também pode ser traçada em relação ao atendimento às demandas dos movimentos sociais que reivindicavam, além do direito à moradia, o uso e a apropriação do Centro pelas classes populares. Evidenciou-se, como tendência, uma maior penetração dessas reivindicações nas gestões mais progressistas, como nas administrações do Partido dos Trabalhadores, com as prefeitas Luiza Erundina e Marta Suplicy.

Por outro lado, numa evidente simetria, a ideologia difundida pela Associação Viva o Centro passa a determinar boa parte das estratégias para a revalorização do Centro Histórico de São Paulo consumadas pelo poder público ao longo de todo o período analisado. Isso permite considerar que, apesar de haver um conflito na sociedade pelo uso e apropriação do espaço - evidenciado na polaridade de discursos do Fórum Centro Vivo e da Associação Viva o Centro -, o poder público tende a homogeneizar esse processo, em nome da promoção de uma falaciosa diversidade social, contribuindo com um ideal capitalista de produção do espaço, que prioriza a sua apropriação privada em detrimento do seu uso público. Comprometendo, sobretudo, a apropriação destes espaços pelas classes populares. 
os Capítulo 4 


\section{OS Capítulo 4 - O Estatuto e a cidade: incidências e efeitos da Lein ${ }^{\circ} 10.257$ sobre o uso do espaço no Centro de São Paulo.}

No ano de 2001, o governo federal sancionou a Lei $\mathrm{n}^{\circ} 10.257$, denominada Estatuto da Cidade, passando a estabelecer novos parâmetros para a política urbana brasileira pela delimitação de um conjunto de diretrizes e de instrumentos urbanísticos voltados para a normatização do uso da propriedade urbana, tendo como premissa o desenvolvimento de sua função social.

A partir daquele momento ficou determinado que todas as cidades brasileiras com mais de 20 mil habitantes deveriam, mediante a elaboração de um Plano Diretor, definir e regulamentar os instrumentos urbanísticos que passariam a condicionar a propriedade urbana ao cumprimento da sua função social. Os Planos Diretores teriam que respeitar as premissas ou diretrizes designadas no próprio Estatuto da Cidade, dentre as quais estão: a garantia à terra urbana e à moradia; a participação da população na formulação de projetos urbanos; o controle do uso do solo e dos processos especulativos com a terra urbana; a regularização fundiária das áreas ocupadas por população de baixa renda etc.

Grande parte dessas diretrizes está fundamentada nos ideários de justiça social e reforma urbana reivindicados pelo Fórum Nacional de Reforma Urbana (FNRU), que há anos tem mobilizado parte das classes populares da sociedade em defesa do "direito à cidade", da "gestão democrática das cidades" e da "função social da cidade e da propriedade urbana".

Tornou-se consensual o reconhecimento de que a sanção do Estatuto da Cidade - em função das diretrizes e dos instrumentos que o sustentam - representa um avanço na história da política urbana brasileira, tendo em vista a criação de normas para regulação do uso do solo urbano, as quais tendem a conflitar com "direitos" e práticas já institucionalizados em nossa sociedade. Tais “direitos” e práticas usualmente definem a quem é possível a apropriação do espaço urbano, o acesso aos serviços públicos, a garantia aos direitos constitucionais etc.

Entretanto, as contradições intrínsecas ao próprio conteúdo do Estatuto da Cidade, assim como as resistências à sua execução colocam em questão a possível efetividade das avançadas diretrizes e instrumentos do Estatuto. Os proprietários de imóveis e o mercado imobiliário são os principais agentes que questionam a nova lei, e 
defendem assim, o seu status quo e a apropriação do espaço como condição para a reprodução do capital.

Ainda neste sentido, deve-se considerar que esta legislação urbanística (pautada nos ideários de justiça social e democracia) se afirma no exato momento de conformação da sociedade capitalista, onde os setores hegemônicos - não sem o aval dos governos locais - passam a induzir a produção do espaço segundo os seus interesses mais particulares. Portanto, têm uma concepção de apropriação espacial que conflita com os interesses da parcela restante da sociedade.

A análise aqui realizada pretende compreender de que modo o Estatuto da Cidade interfere na questão das áreas centrais e no problema da habitação nessa mesma região. Mas além das premissas do estatuto, as diretrizes do Plano Diretor Estratégico do município de São Paulo (Lei $n^{\circ} 13.430 / 02$ ) também servem de suporte para esta investigação. De um modo específico, busca-se compreender de que forma essas normas e instrumentos da política urbana existente em São Paulo incidem sobre o uso do solo na porção central da cidade no período recente; e quais os resultados já podem ser colhidos como efeito de sua aplicação. Antes de avançar nesta investigação, será feita a análise do percurso histórico/político de promulgação do Estatuto da Cidade, bem como, um delineamento do seu conteúdo.

\subsection{Estatuto da Cidade: processos anteriores à sanção da Lei nº 10.257}

Embora a Lei Federal $\mathrm{n}^{\circ} 10.257$, denominada Estatuto da Cidade - que regulamentou os capítulos de política urbana da Constituição Federal de 1988 -, tenha sido sancionada no ano de 2001, o seu processo de tramitação foi relativamente extenso e marcado pela luta persistente dos movimentos sociais que, com maior ênfase nos anos 80, passaram a pressionar o Estado pela reforma urbana das cidades brasileiras. Também contribuiu para o surgimento dessa lei a iniciativa de setores progressistas do poder público que passaram a evidenciar um interesse em constituir normas de regulação para o uso do espaço urbano.

Não raro nos estudos acadêmicos que perscrutam o Estatuto da Cidade se faz referência a uma atuação marcante das entidades e movimentos sociais no processo de constituição dessa Lei Federal $^{100}$. Estas análises, em geral, reconhecem que o Estatuto da Cidade incorpora parte das demandas manifestas pelos movimentos sociais, bem

\footnotetext{
${ }^{100}$ CARDOSO (2003); GRAZIA (2003); MARICATO (2001); RIBEIRO (2003); RODRIGUES (2004); SILVA, J. (2003).
} 
como deve a sua aprovação à pressão política realizada por esses agentes que, ao longo de um pouco mais de vinte anos, têm encampado a luta pela reforma urbana no Brasil.

De um modo geral, os movimentos sociais em prol da reforma urbana brasileira reivindicam junto ao Estado medidas que assegurem justiça social, e garantam a toda sociedade uma série de direito, dentre os quais: o direito à moradia, o direito aos equipamentos urbanos e serviços públicos, o direito de participação da população no processo de decisão política; o cumprimento da função social da propriedade etc.

Os ideais acima referidos estão coadunados em torno dos objetivos do Fórum Nacional pela Reforma Urbana (FNRU). Este Fórum é composto por movimentos populares, organizações não governamentais, instituições de pesquisa e demais entidades sociais ${ }^{101}$ que, conforme aponta Grazia, nos idos de 1980 reacenderam o debate a respeito da reforma urbana no Brasil ${ }^{102}$. Estes movimentos passaram a compreender que o processo de produção das cidades brasileiras estava submetido aos interesses privados dos proprietários imobiliários, logo, aos de critérios rentabilidade econômica do solo urbano. Estes mesmos critérios rentistas é que determinam os modos de apropriação do espaço, e como conseqüência estabelecem um fosso entre uma parcela da sociedade cujo poder aquisitivo possibilita o acesso à cidade com urbanidade - habitação e demais serviços públicos (GRAZIA, 2003) -, em contraposição à grande maioria da população, cuja pobreza faz viver à margem desses mesmos direitos. Segundo Ribeiro, esta compreensão dos problemas urbanos formulada pelo FNRU se opõe à outra visão do processo de produção das cidades brasileiras que, partindo de um "diagnóstico demográfico", procura explicar os problemas urbanos (favelização e a desigualdade social de acesso aos equipamentos urbanos) como resultado do elevado

\footnotetext{
101 A atual coordenação FNRU é composta por: Federação de Órgãos para Assistência Social e Educacional, Confederação Nacional de Associações de Moradores, Instituto Pólis, Central dos Movimentos Populares, União Nacional por Moradia Popular, Movimento Nacional de Luta por Moradia, Associação dos Geógrafos Brasileiros, Federação Nacional de Arquitetos e Urbanistas, Federação Interestadual de Sindicatos de Engenheiros, Federação Nacional de Associações de Funcionários da Caixa Econômica Federal, Centro de Assessoria à Autogestão Popular, Instituto Brasileiro de Análises Sociais e Econômicas etc. (FÓRUM NACIONAL DE REFORMA URBANA, 2006).

${ }^{102}$ É necessário apontar que as discussões sobre a questão urbana principiaram em períodos anteriores à década de 80. Conforme recupera Maricato (2001), realizou-se na década de 60 o Seminário Nacional de Habitação e Reforma Urbana (organizado pelo Instituto de Arquitetos do Brasil - IAB) e, anos 70, aconteceu a Conferência Nacional dos Bispos Brasileiros (CNBB) a qual lançou o documento "Solo urbano e Ação Pastoral", em que a questão da reforma urbana ganha evidência e se torna mote para as mobilizações da sociedade civil.
} 
crescimento e concentração de população nos grandes centros urbanos (RIBEIRO, 2003).

Segundo Grazia, são três os princípios que passam a nortear as práticas do Fórum Nacional de Reforma Urbana:

1) Direito à Cidade e à Cidadania, entendido como uma nova lógica que universalize o acesso aos equipamentos e serviços urbanos, a condições de vida urbana digna e ao usufruto de um espaço culturalmente rico e diversificado [...]. 2) Gestão Democrática da Cidade entendida como forma de planejar, produzir [...] governar cidades submetidas ao controle e participação social [...] 3) Função Social da Cidade e da Propriedade entendida como a prevalência do interesse comum sobre o direito individual de propriedade [...] (GRAZIA, 2003, p. 54).

Deve-se ressaltar que o conjunto dessas idéias constitui um aporte inovador às práticas que até o período recente determinam a produção e apropriação do espaço urbano. Isso porque, tais idéias colocam em relevo a participação popular no campo de tomada de decisões políticas da cidade e a função social da propriedade (como questionamento do uso privado da propriedade urbana). Neste sentido, o Fórum Nacional de Reforma Urbana pretende chamar atenção para a criação e adoção, por parte do poder público, de instrumentos normativos que passem a assegurar um conjunto de direitos sociais que induzam a apropriação do espaço urbano pela sociedade em sua coletividade. Do mesmo modo, espera-se alcançar o reconhecimento das classes populares como agentes políticos da cidade, pela participação na formulação de políticas públicas direcionadas à defesa dos interesses sociais.

Entretanto, é necessário apontar que os movimentos sociais, em nome da defesa da função social da propriedade urbana, passam a demandar o acesso à propriedade, e não questionar o seu fundamento. Contudo, a propriedade privada por existir (está definida constitucionalmente) determina a apropriação do espaço urbano, instituindo a prevalência dos direitos privados acima dos interesses e direitos coletivos. Assim sendo, a propriedade privada gera desigualdade e segregação sócio-espacial.

É no contexto de construção da nova Constituição Federal Brasileira (aprovada em 1988) que a atuação do Fórum Nacional de Reforma Urbana terá destaque, dada a sua estratégia e mobilização para aprovar, em 1987, a Emenda de Reforma Urbana. Ou seja, uma iniciativa popular em defesa da inclusão na Constituição Federal dos artigos 182 e 183 referentes à política urbana, que tinham como diretriz principal a submissão da propriedade privada ao cumprimento de sua função social. 
Embora, a Constituição tenha sido aprovada com a inclusão dos respectivos $\operatorname{artigos}^{103}$, isso não se realizou sem contrariar algumas das reivindicações dos movimentos e entidades sociais, o que pode ser exemplificado em relação a questão da Função Social da Propriedade. Enquanto o Fórum Nacional de Reforma Urbana esperava que a Constituição determinasse esta diretriz como sendo auto-aplicável, isso não aconteceu, pois o texto constitucional delegou ao Plano Diretor Municipal a função de definir quando uma propriedade cumpre a sua função social. Dessa maneira, esta diretriz dependia de novas leis para ser regulamentada, logo, de novas negociações e enfrentamentos com os setores conservadores que a ela se opunham. Tal como expresso no $\S 2^{\circ}$ do artigo 182 da Constituição Federal: “A propriedade urbana cumpre sua função social quando atende às exigências fundamentais de ordenação da cidade expressas no Plano Diretor”. Assim, foram frustradas as intenções do FNRU, pois a União deslocou a efetivação de tal diretriz para as instâncias de decisão do poder público municipal, que podem, a depender da organização mais ou menos forte dos movimentos sociais, ser muito influenciadas pelas relações clientelistas ou de poder econômico.

Deve-se apontar também que a promulgação da nova Constituição brasileira não resultou na regulamentação dos capítulos de política urbana. Tal fato deu início a um novo processo de negociação do Fórum de Reforma Urbana com o governo federal, que terminou somente no ano de 2001, com a aprovação do Estatuto da Cidade que fez executar os artigos 182 e 183 previstos constitucionalmente ${ }^{104}$.

Conforme apontado no início deste item, o caminho que conduziu à formulação do Estatuto da Cidade passou ainda por tentativas sucessivas de elaboração institucional de leis para regular o uso do espaço urbano. Como analisam Grazia (2003) e Cardoso (2003), foi buscando enfrentar o processo de especulação imobiliária que a Comissão Nacional de Desenvolvimento Urbano (CNDU) tentou aprovar uma Lei de Desenvolvimento Urbano (LDU) no ano de 1977. Esta lei tinha como diretrizes: o estímulo ao planejamento urbano como medida para controle do uso do solo e de

\footnotetext{
103 Conforme previsto na Constituição brasileira ART. 182 "A política de desenvolvimento urbano, executada pelo poder público municipal, conforme diretrizes gerais fixadas em lei, tem por objetivo ordenar o pleno desenvolvimento das funções sociais da cidade e garantir o bem-estar de seus habitantes". Já o ART. 183 estabelece que "Aquele que possuir como sua área urbana de até duzentos e cinqüenta metros quadrados, por cinco anos, ininterruptamente e sem oposição, utilizando-a para a sua família, adquirir-lhe-á o domínio, desde que não seja proprietário de outro imóvel urbano ou rural".

${ }^{104}$ Como poderá ser enfatizado adiante, o Estatuto da Cidade manteve o cumprimento da função social da propriedade urbana atrelado às determinações do Plano Diretor municipal.
} 
expansão das cidades; a função social da propriedade; a regularização fundiária e urbanização de áreas ocupadas por população de baixo poder aquisitivo; o estímulo à participação comunitária na gestão do poder público, etc. (CARDOSO, 2003, p. 27-28).

Note-se que a conjuntura política daquela época era marcada pelo regime militar, portanto, a elaboração desta lei estava associada ao trabalho de setores mais progressistas existentes no CNDU. Segundo Ribeiro, tal ambigüidade foi expressa pela imprensa escrita que à época "atribuía às elites autoritárias, imbricadas com as oligarquias regionais e locais que tradicionalmente viviam da riqueza patrimonial, intenções de regular uma das fontes de ganhos patrimoniais: o solo urbano" (RIBEIRO, 2003, p. 12).

Todavia, é somente em 1983 que este projeto é encaminhado ao Congresso Nacional e se torna o Projeto de Lei $\mathrm{n}^{\circ} 775 / 83$. O tempo transcorrido entre a sua elaboração e a sua transformação em Projeto de Lei, justifica-se pela resistência dos setores conservadores do poder público que, preocupados com a defesa dos interesses do mercado imobiliário, impuseram restrições ao trâmite da LDU nas instâncias do poder legislativo.

Conforme analisa Ribeiro (2003), o resgate da Lei de Desenvolvimento Urbano, que pelas mãos do próprio regime autoritário foi alçada à condição de Projeto de Lei, estava atrelado à iminência de reabertura política do país e a uma estratégia dos próprios militares em lançar mão de um tema que fosse sedutor e de interesse de toda a sociedade, convertendo-se futuramente em apoio das massas à sua continuidade no poder.

Transcorrida a reabertura política, no processo de elaboração da nova Constituição Brasileira os preceitos que já estavam colocados pelos movimentos sociais, assim como as diretrizes da Lei de Desenvolvimento Urbana, foram retomados para e elaboração do capítulo constitucional de política urbana, preconizado nos artigos 182 e 183.

Entre os anos de 1988 e 2001, período que se refere à promulgação da Constituição Brasileira e a regulamentação do Estatuto da Cidade, o Fórum Nacional pela Reforma Urbana manteve uma mobilização popular permanente visando pressionar o Estado para que o capítulo de política urbana da Constituição ganhasse efetividade. Conforme analisado por Grazia (2003), desde a primeira tentativa de regulamentar os artigos 182 e 183 da Constituição, por meio do Projeto de Lei ${ }^{\circ}{ }^{181 / 89}$ elaborado pelo Senador Pompeu de Souza - $\quad$ este projeto foi, posteriormente, aprovado no Senado 
Federal e convertido em Projeto de Lei n5.788/90 - foi vital a negociação dos movimentos e entidades sociais com os parlamentares para driblar os setores que se opunham às diretrizes que comporiam o Estatuto.

A oposição à sanção do Estatuto da Cidade estava formada por parlamentares ligados ao setor imobiliário, por entidades que representavam os proprietários imobiliários e empresários da construção civil, que também passaram a pressionar o Estado na defesa dos seus interesses. Esta pressão teria como resultado a criação de barreiras para tramitação do projeto de lei sobre a política urbana no Plenário da Câmara e Senado (GRAZIA, 2003).

Na empreitada pela regulamentação do Estatuto da Cidade, por vezes, o Fórum Nacional de Reforma Urbana teve que ceder, em relação a algumas de suas propostas, como maneira para fazer seguir adiante o projeto de lei que continha as diretrizes para a política urbana. Segundo Grazia, “a estratégia usada nessas negociações foi retirar alguns detalhes incluídos em artigos que, embora importantes, não atrapalhavam o sentido da matéria [...]" (GRAZIA, 2003, p. 62) e que poderiam ser retomadas ou renegociadas em momentos posteriores.

No ano de 2001, após aprovação unânime no Senado e a sanção presidencial, o Estatuto da Cidade foi regulamentado. Este fato passou a ser considerado pelos movimentos sociais como uma vitória, muito embora, neste processo tenha havido perdas significativas em relação às premissas levantadas pelo próprio Fórum Nacional de Reforma Urbana. Dentre essas premissas se inclui o mantimento do princípio da função social da propriedade submetido ao Plano Diretor, e o veto presidencial à lei de "Concessão de Uso Especial para Fins de Moradia".

A “Concessão de Uso Especial para Fins de Moradia” propiciaria às famílias que ocupam terras públicas há mais de cinco anos o direito à permanência nessas áreas. Isso poderia trazer um novo alento aos numerosos moradores de favelas, cortiços, loteamentos irregulares e clandestinos existentes nas grandes cidades brasileiras. Segundo Grazia, "o argumento utilizado para o veto [...] era o medo de que a lei se tornasse um incentivo à população para ocupar terra pública [...]" (GRAZIA, 2003, p. 63-64).

A partir da regulamentação do Estatuto da Cidade a luta dos movimentos sociais tem se dado com especial ênfase em nível local, tendo em vista o fato do cumprimento da função social da propriedade estar atrelado à elaboração, no município, dos Planos Diretores Estratégicos. Ao mesmo tempo, a ação dos movimentos tem pressionado o 
poder público em busca da efetividade do Estatuto da Cidade, como forma de orientar, por meio da elaboração dos Planos Diretores, políticas públicas que determinem a produção da cidade na direção dos interesses sociais. Essa tarefa tem se mostrado árdua, realizando-se mediante o constante enfretamento com os setores econômicos que, na contramão dos anseios das classes populares, procuram fazer do espaço o meio para a reprodução do capital.

\subsection{Delineamento geral sobre o conteúdo do Estatuto da Cidade}

Passados onze anos da promulgação da Constituição Federal brasileira, o Governo Federal sancionou em 2001 o Estatuto da cidade, Lei Federal nº10.257 que regulamenta os artigos 182 e 183 do capítulo de política urbana do texto constitucional e "estabelece normas de ordem pública e interesse social que regulam o uso da propriedade urbana em prol do bem coletivo, da segurança e do bem-estar dos cidadãos, bem como do equilíbrio ambiental" (Cap. 1, art. $1^{\circ}$, par. Único). Neste sentido, o Estatuto da cidade passa a ser o dispositivo legal para "ordenar o pleno desenvolvimento das funções sociais da cidade e da propriedade [...]" (Cap. 1, art. $2^{\circ}$ ). Entretanto, ele delega aos municípios, mediante elaboração de um Plano Diretor, o cumprimento desses objetivos ao dispor que "a propriedade urbana cumpre a sua função social quando atende às exigência fundamentais de ordenação da cidade expressas no plano diretor, assegurando o atendimento das necessidades dos cidadãos quanto à qualidade de vida, à justiça social e ao desenvolvimento das atividades econômicas [...]" (Cap.3, art. 39).

Como já analisado, o conjunto de normas que regulam o uso da propriedade urbana e que compõem o Estatuto da Cidade foi regulamentado na esteira das reivindicações, debates e negociações travados com o poder público e suscitados pelos movimentos sociais engajados na luta pela reforma urbana. Esses movimentos populares, já na década de 80 , estavam organizados em torno da inserção do capítulo de política urbana no texto da nova Constituição brasileira, que foi promulgada em 1988.

Os movimentos sociais pela Reforma Urbana passaram a pressionar o Estado para o enfrentamento dos problemas urbanos relacionados à iniqüidade de acesso aos bens e serviços públicos, à terra urbana, ao trabalho, ao lazer etc. Deste modo, cobrando do poder público a institucionalização de direitos que assegurassem justiça social, ou ainda, o reconhecimento do "direito à cidade" para todos os cidadãos. Assim, como 
afirma Grazia: “[...] a Lei Federal 10.257/01 expressa o debate urbano acumulado nos últimos 20 anos, bem como boa parte dos princípios estabelecidos pelo Movimento da Reforma Urbana" (GRAZIA, 2003, p. 60).

A partir da aprovação do Estatuto das Cidades, os municípios brasileiros ${ }^{105}$ passaram a dispor de instrumentos normativos para a realização de uma política de ordenação do uso do solo urbano. Esses mesmos instrumentos abriram a possibilidade de coibir as estratégias que produzem a segregação sócio-espacial das classes populares da sociedade: pela tendência ao enfretamento da especulação imobiliária, mediante a delimitação de normas que tornam possível pôr em uso os imóveis mantidos vazios ou subutilizados; por tornar legal a regularização fundiária das áreas ocupadas por população de baixa renda; por instituir a participação da população nos processos de formulação e execução de políticas urbanas voltadas ao atendimento do interesse social etc.

No período recente, aprovação do Estatuto da Cidade é encarada pelos movimentos sociais como um passo adiante em relação ao caminho para a conquista do “direito à cidade". Este sentimento de otimismo não é contestado pela grande maioria dos acadêmicos ${ }^{106}$ que consideram o Estatuto como um marco histórico para a legislação urbana brasileira, assinalando a sua importância e o seu caráter promissor para rever o rumo da produção do espaço urbano e do crescimento das cidades no Brasil.

As positividades do Estatuto da Cidade são afirmadas frente a um cenário urbano no qual a maior parcela da população vive em lugares distantes do trabalho, onde os serviços públicos são escassos. Tais condições podem ser presenciadas cotidianamente nas favelas, cortiços e loteamentos irregulares que, em geral, se multiplicam pela periferia das grandes cidades brasileiras. Pode-se afirmar que a maioria esmagadora dessa população vive em condições que podem ser consideradas subumanas. Já nos lugares regulados pelo mercado imobiliário, onde se concentram a maior parte dos investimentos públicos, a apropriação do espaço se torna restrita às camadas de maior poder aquisitivo, devido ao preço elevado da propriedade urbana.

\footnotetext{
${ }^{105}$ Trata-se, na verdade, de apenas parte dos municípios brasileiros, uma vez que o Plano Diretor é obrigatório apenas para municípios com mais de vinte mil habitantes.

${ }^{106}$ CYMBALISTA (2001); MARICATO (2001); SILVA, J. (2003)
} 
Estes mesmos lugares podem coincidir com as regiões onde há um grande número de imóveis deixados vazios à espera de valorização futura.

Deste modo, o Estatuto da Cidade, enquanto dispositivo legal que permite à administração municipal regular o uso do solo urbano, pode representar uma possibilidade de intervenção no mercado imobiliário, estimulando outras formas de apropriação desse espaço que permitam à maior parte da população brasileira viver em lugares que não sejam apenas aqueles onde predominam a carência e pobreza extrema.

Assim sendo, tal como afirma Silva, J., "é indiscutível que a lei do Estatuto da Cidade seja uma grande conquista e sinal de novos tempos na construção de cidades mais justas, humanas e bonitas [...] portadoras de direitos sociais inerentes à dignidade humana" (SILVA, J., 2003, p. 31). Entretanto, apesar das discussões e análises acadêmicas reafirmarem um caráter promissor do Estatuto da cidade, elas procuram, por outro lado, ponderar a respeito das reais possibilidades da sua efetividade para conter as desigualdades existentes nas cidades brasileiras (no que diz respeito ao uso do solo), e reverter o seu processo de segregação sócio-espacial.

Nesse sentido, aponta-se para a inexorável presença e atuação dos proprietários de terras e do próprio mercado imobiliário na produção do espaço urbano brasileiro. Considera-se que o Estado tem sido indiferente - quando não, grande incentivador - aos interesses desses agentes que se apropriam privadamente do espaço e traçam estratégias para valorizá-lo e mantê-lo como meio constante para a reprodução do seu capital. São esses mesmos interesses que empurram as classes populares rumo à periferia das cidades, e na maior parte das vezes, estimulam a ocupação de áreas ilegais como única alternativa para moradia dessa população.

Portanto intervir no rumo de produção das cidades brasileiras é estabelecer um limite às forças e interesses que já estão enraizados na sociedade patrimonialista, e que muitas vezes são alimentados por políticas de privilégios traçadas pelo próprio poder público. Neste sentido, é possível questionar se as possibilidades abertas às administrações públicas, expressas no Estatuto da Cidade, virão a se constituir de fato como um elemento para o enfrentamento desses interesses, conduzindo à produção do espaço segundo as demandas de toda à sociedade. Como analisa Maricato:

É evidente [...] a importância do aperfeiçoamento de toda a legislação urbanística. A experiência brasileira mostra, no entanto, que conquistas formais legais nunca serão suficientes. Todos reconhecem que no Brasil há leis que pegam e leis que não pegam, tudo depende do que se trata e de quem se trata, ou seja, tudo depende dos interesses em jogo (MARICATO, 2001, p.92, grifos da autora) 
Numa outra perspectiva é importante considerar que, além do próprio enfrentamento de interesses existente na sociedade, outros aspectos tendem a limitar a efetividade dos instrumentos normativos do Estatuto da Cidade. Estes elementos estão diretamente associados às incertezas e contradições intrínsecas à própria lei, por exemplo a falta de clareza em relação às categorias que estão atreladas à questão da função social da propriedade. Isso acontece, pois o Estatuto não especifica objetivamente o que se pode entender por imóvel subutilizado ou não utilizado. Neste caso, como analisou Rodrigues, "há ainda ausência de critérios básicos para definir quando uma propriedade urbana está aguardando valorização futura, para averiguar se está cumprindo a função social e aplicar os instrumentos do Estatuto" (RODRIGUES, 2004, p. 21).

Em relação ao conteúdo do Estatuto da Cidade pode-se dizer, de um modo abrangente, que a Lei $\mathrm{n}^{\circ} 10.257 / 01$ se desdobra em torno de Diretrizes Gerais e de Instrumentos de intervenção (política e jurídica) a partir dos quais, mediante a elaboração de um Plano Diretor pelos municípios, pretende-se efetivar a política urbana de regulação do uso do solo, tendo como premissa básica ordenar o cumprimento das funções sociais da cidade e da propriedade urbana.

Como disposto no Capítulo 1, artigo $2^{\circ}$ do Estatuto da Cidade, o desenvolvimento das funções sociais da cidade e da propriedade será encaminhando por meio de diretrizes que contemplem a garantia: à moradia, à terra e infra-estrutura urbanas, ao trabalho e ao lazer - entendidos como "direito à cidade sustentáveis"; à participação da população na formulação e execução de projetos urbanos - como forma de assegurar a "gestão democrática" das cidades; ao planejamento das cidades - como meio para "evitar e corrigir distorções do crescimento urbano"; à ordenação e controle do uso do solo - visando evitar a sua "utilização inadequada", impedir a especulação imobiliária, a manutenção imóveis "subutilizados ou não utilizados" no espaço urbano e a deterioração das áreas urbanas; à recuperação dos investimentos públicos decorrentes da valorização de imóveis urbanos; à regularização fundiária das áreas da cidade ocupadas por população de baixa renda, etc.

No que concerne à delimitação dessas diretrizes, é possível aferir que o Estatuto da Cidade reconhece alguns dos problemas urbanos e conflitos recorrentes em cidades brasileiras, nas quais - a exemplo de São Paulo - o processo de produção do espaço tem se efetivado pela multiplicação de moradias irregulares, como resultado da ocupação de 
terras públicas e privadas sem uso, geralmente, localizadas na periferia das grandes cidades. Para estes casos, o Estatuto passa a determinar medidas de regularização fundiária.

O que pode se constituir como outra possibilidade para essa população de baixo poder aquisitivo - na maior parte das vezes mantida à margem da legalidade urbana - é a regulação (pelo poder público) sobre os imóveis mantidos sem uso em áreas urbanizadas da cidade. Neste caso, a lei abre um precedente formal para que se possa instituir uma finalidade social ou destinar ao uso as propriedades imobiliárias mantidas vazias e à mercê das estratégias especulativas. Porém, é necessário observar novamente que no texto da Lei $n^{\circ} 10.257$ não há maiores especificações em relação ao que se entende por imóveis subutilizados ou não utilizados, o que pode constituir uma barreira à efetividade desta matéria.

Quanto a diretriz que diz respeito à participação da população na definição de projetos urbanos, ela pode vir a se constituir como um aporte significativo rumo à construção de gestões democráticas, caso seja plenamente executada pelas administrações municipais. Isso implicaria na concessão aos cidadãos do direito de intervir efetivamente no campo de tomadas de decisões políticas sobre a cidade. Por hora, o Estatuto da cidade determina genericamente que esta participação deve se dar "na formulação, execução e acompanhamento de planos, programa e projetos de desenvolvimento urbano" (art. $2^{\circ}$, inciso II).

Como forma de intervir no uso do solo urbano e viabilizar as diretrizes expressas no Estatuto da Cidade, a Lei n ${ }^{\circ} 10.257$ (Cap. 2, art. 4º disponibiliza para os municípios a utilização de instrumentos jurídicos e políticos e de institutos tributários e financeiros. Dentre os instrumentos de cunho jurídico e político constam: o parcelamento, edificação ou utilização compulsórios do solo urbano, caso este não esteja edificado, subutilizado ou não utilizado nas áreas incluídas no plano diretor; a desapropriação com pagamento em títulos da dívida pública, aplicável após cinco anos de cobrança do IPTU (progressivo) e sem que o solo urbano tenha sido parcelado, edificado ou utilizado; instituição de zonas especiais de interesse social, voltadas prioritariamente para habitação de interesse social; concessão de uso especial para fins de moradia ${ }^{107}$; usucapião especial de imóvel urbano; direito de preempção, que confere ao poder público a preferência na aquisição de imóvel particular em alienação; outorga onerosa

\footnotetext{
107 Como já foi considerado anteriormente, este artigo foi vetado pelo então Presidente da República
} Fernando Henrique Cardoso. 
do direito de construir, que permite o direito de construir acima do coeficiente determinado no plano diretor e mediante pagamento de contrapartida pelo beneficiário ao poder público; operações urbanas consorciadas, etc.

Dentre os instrumentos tributários, inclui-se o imposto sobre a propriedade predial e territorial urbana (IPTU) progressivo no tempo; aplicável, pelos municípios, caso não seja cumprido no prazo determinado o parcelamento, edificação e utilização compulsórios do solo urbano.

Tal como referido anteriormente, o Estatuto da Cidade estabelece como diretriz a ordenação e controle do uso do solo para impedir a especulação imobiliária sobre imóveis da cidade, os quais, a partir de estratégias rentistas dos proprietários imobiliários, são mantidos subutilizados ou sem utilização prevendo futura valorização. Neste caso, restabelecer o uso desses imóveis seria o meio de fazer prevalecer a função social da propriedade na cidade. Como potenciais instrumentos viabilizadores desses objetivos, o Estatuto passa a determinar a obrigatoriedade do parcelamento, edificação ou utilização compulsórios do solo urbano ${ }^{108}$. No caso de descumprimento desta medida, há a possibilidade de penalizar o proprietário com a cobrança do IPTU progressivo no tempo. Esta medida consistiria na aplicação de alíquotas de imposto, cujo valor seria elevado continuamente durante o prazo de cinco anos.

Caso do proprietário do imóvel ocioso resista à pressão imposta pela cobrança do IPTU progressivo, o Estatuto ainda prevê a desapropriação deste imóvel como recurso final para efetivar o parcelamento, edificação ou utilização da propriedade urbana. Segundo Cymbalista "esse conjunto de instrumentos pode representar uma possibilidade de intervir efetivamente no crescimento da cidade, promovendo uma ocupação mais intensa nas áreas onde a infra-estrutura é mais presente [...]" (CYMBALISTA, 2001, p. 1).

Entretanto, ao submeter o cumprimento do parcelamento, edificação ou utilização compulsórios à elaboração de lei municipal específica para a área a ser submetida ao Instrumento, o Estatuto da Cidade estabelece um elemento de morosidade e até mesmo de veto a este instrumento. Isso porque implicaria em difícil e necessário consenso em torno de uma medida que afeta diretamente os negócios do setor

\footnotetext{
108 Porém, o Estatuto da Cidade estabelece que uma lei específica municipal deve ser elaborada para determinar o parcelamento, edificação ou utilização compulsórios do solo urbano não edificado, subutilizado ou não utilizado. Ao mesmo tempo prevê que a área/imóvel sob intervenção deve, ainda, estar incluída e delimitada no plano diretor.
} 
imobiliário e dos proprietários fundiários, cujos interesses estão representados nas câmaras de vereadores dos municípios.

Como expresso na Lei $\mathrm{n}^{\circ} 10.257$, cabe às administrações públicas municipais regulamentar, por meio da elaboração do Plano Diretor, as diretrizes e instrumentos contidos no Estatuto da Cidade. Deste modo, institui-se e determina-se que a propriedade urbana cumprirá a sua função social quando atender às ordenações contidas no Plano Diretor.

O plano diretor é obrigatório para cidades com mais de 20 mil habitantes, deste modo, segundo Rodrigues (2004), o critério para se fazer cumprir a função da propriedade e da cidade não é espacial, mas sim populacional. Deste modo, estará restrito a uma parcela muito pequena de municípios brasileiros cujo contingente populacional atinge o número determinado pelo Estatuto da Cidade (neste caso somente $20 \%$ dos municípios brasileiros). Sendo assim, o Estatuto ao "transferir" a regulamentação dos seus instrumentos pela aplicação do plano diretor municipal, e tendo como critérios o tamanho da população, restringe a sua importância a uma parcela pequena de todo o território nacional.

Frente a este delineamento geral do Estatuto da Cidade, a análise que seguirá busca compreender como vem se efetivando e quais os resultados que já puderam ser colhidos em relação à incidência da Lei nº10.257/01 no município de São Paulo.

\subsection{A questão do Centro à luz do Estatuto da Cidade e do Plano Diretor de São Paulo.}

Há tanto no discurso do Governo Federal - como fica explícito no documento "Plano Diretor Participativo: guia para elaboração pelos municípios e cidadãos" quanto no do poder público municipal de São Paulo - evidenciado no documento "São Paulo Plano Diretor Estratégico: Cartilha de Formação" - o entendimento de que o esvaziamento populacional das áreas centrais e históricas ${ }^{109}$ é um dos principais problemas a ser enfrentado pelo Plano Diretor Estratégico.

No que tange especificamente ao discurso elaborado pelo Governo Federal, o ponto de partida para o encaminhamento deste problema é a identificação de que há nas áreas centrais e históricas espaços edificados vazios ou subutilizados que, se submetidos

\footnotetext{
109 Neste caso utiliza-se a denominação "áreas centrais e históricas”, pois o Governo Federal reconhece que nem sempre o centro histórico das cidades corresponda espacialmente à sua área central, muito embora isso ocorra com freqüência.
} 
aos instrumentos normativos contidos no Plano Diretor - com vistas para o cumprimento da função social da propriedade - podem, de um lado, propiciar uma nova ocupação desse espaço, contribuindo para minorar os problemas relacionados ao déficit habitacional das grandes cidades brasileiras.

O que o Governo Federal propõe às administrações municipais é que o Plano Diretor, pautado pelo cumprimento da função social da propriedade urbana, seja o ponto inicial para uma política de reabilitação das áreas centrais. Isso porque ele propiciaria um novo aproveitamento do estoque imobiliário aí existente, substituindo uma prática que define a expansão horizontal das cidades brasileiras rumo às áreas periféricas (BRASIL, 2005).

Neste aspecto, o discurso do Governo Federal encontra um paralelo com as formulações do poder público municipal, que estabelece uma relação de causa-efeito entre o esvaziamento das áreas centrais e o crescimento das áreas de urbanização precária. Nesse sentido, aponta-se que as áreas dotadas de maior infra-estrutura e emprego são aquelas que têm registrado perda de população. Isso ocorre enquanto as regiões periféricas - com baixa infra-estrutura e poucos investimentos públicos e privados - apresentam um elevado crescimento populacional. Este crescimento é apontado como conseqüência de um processo migratório no interior da própria cidade, resultado dos altos custos de moradia nas áreas centrais, que fazem com que a população (mais pobre) saia dessas regiões mais valorizadas e vá buscar moradia em áreas cada vez mais distantes e baratas (SÃO PAULO, 2003).

É pela constatação de que o Plano Diretor, ao conter instrumentos de ordenação do uso e ocupação do solo, pode contribuir para combater esse quadro de segregação sócio-espacial que o Governo Federal passa a recomendar que:

O Plano diretor deve incidir diretamente nas diretrizes locais da política habitacional, induzindo o repovoamento das áreas centrais e vazios urbanos, destinando áreas infra-estruturadas na cidade para provisão de habitação de interesse social, democratizando o acesso ao solo urbano e à própria cidade, para a população de baixa renda [...] (BRASIL, 2005, p. 75).

Segundo o poder público municipal de São Paulo, a partir do processo de esvaziamento populacional do centro, diagnosticou que inúmeros imóveis têm permanecido vazios durante anos nessas regiões. Este fato tem gerado uma penalização à população mais pobre que "é expulsa cada vez para mais longe, gasta tempo e dinheiro no transporte e ainda mora em bairros com baixa qualidade de vida" (SÃO 
PAULO, 2003, p. 15), e representa também um prejuízo a toda à sociedade, pois faz com que Estado tenha de investir (minimamente) nas áreas periféricas, quando as regiões com infra-estrutura instalada permanecem vazias (SÃO PAULO, 2003).

Para o enfrentamento do problema acima delineado, o poder público municipal em uma aparente consonância com as recomendações do Governo Federal - sugere o estímulo ao uso habitacional das áreas centrais, como forma de povoar essas regiões e conter o crescimento populacional nas áreas tidas como precárias e de proteção ambiental. Essa medida se tornaria possível a partir da efetivação de determinados instrumentos previstos no Plano Diretor, dentre os quais estão: a delimitação de Zonas Especiais de Interesse Social do tipo 3 (Zeis 3) - "que reservam determinadas áreas centrais, bem localizadas e com infra-estrutura completa para a utilização prioritária de população de baixa renda..."; a edificação e utilização compulsórios - "visam combater a manutenção de terrenos e edifícios vazios e subutilizados, que poderiam ser usados para Habitação de Interesse Social (HIS)"; a transferência do direito de construir - "em casos de doação de imóveis nos quais haja interesse público para uso como HIS [o doador] recebe o direito de utilizar o potencial construtivo daquele imóvel em outro terreno, sem precisar pagar outorga onerosa" (SÃO PAULO, 2003, p. 30).

Associado ao estímulo ao uso habitacional do Centro, e como forma de fazer cumprir a função social da propriedade dos imóveis vazios ou subutilizados presentes nas áreas centrais, o poder público pretende, ao menos no plano formal, penalizar os proprietários dos imóveis ${ }^{110}$ que os mantém dentro dessas condições. Para o cumprimento de tal penalização, o Estado passaria a dispor (de modo gradual) do emprego dos seguintes instrumentos do Plano Diretor: parcelamento, edificação e utilização compulsórios; Imposto Predial e Territorial Urbano (IPTU) progressivo no tempo; desapropriação e pagamento com títulos da dívida pública. Ou seja, todo um conjunto de instrumentos que, tal como afirma Cymbalista, abre possibilidades para combater a especulação imobiliária na cidade e "pode[m] representar uma possibilidade de intervir efetivamente no crescimento da cidade, promovendo uma ocupação mais intensa nas áreas onde a infra-estrutura é mais presente [...] reduzindo a pressão pela urbanização das áreas periféricas” (CYMBALISTA, 2001, p. 1).

\footnotetext{
110 Essas penalidades estão previstas somente para os imóveis considerados não edificados ou subutilizados localizados nas ZEIS 2 e 3 e nas áreas de Operações Urbanas, nas quais estão inclusas os distritos Sé e República.
} 
Nesse sentido, tanto o Governo Federal quanto o poder público municipal de São Paulo convergem na compreensão de que o Plano Diretor - mediante o cumprimento da função social da propriedade, e pelo aporte que possibilita à reordenação do uso e ocupação do solo - deve propiciar uma nova ocupação para as áreas centrais da cidade, a partir do estímulo ao uso dos imóveis vazios ou subutilizados.

Deve-se apontar que, combinada a uma estratégia de reocupação das áreas centrais, o Governo Federal recomenda aos municípios que efetivem uma política voltada à preservação do patrimônio arquitetônico (histórico e cultural) existente nos seus centros históricos, como forma de intervir nesses espaços permitindo a sua reabilitação.

Por sua vez, esta política de reabilitação das áreas centrais é definida em contraponto às "políticas de conservação de patrimônio". Estas últimas são consideradas como um conjunto de intervenções que exercem um "controle negativo" do uso do espaço, pois se preocupam meramente em criar restrições às mudanças que podem ocorrer nos edifícios históricos (BRASIL, 2005).

Portanto, a conservação do patrimônio passa a ser encarada pelo Estado, como uma política que - ao ser efetivada de modo desarticulado em relação à reabilitação dos centros históricos - emperra o desenvolvimento da cidade por inviabilizar o uso do seu patrimônio "como um bem e como importante base para que se construa um projeto de desenvolvimento local" (BRASIL, 2005, p. 56)

Deste modo, tal como afirma o Governo Federal, a valorização de uma política de reabilitação prevalecendo sobre uma estratégia rígida de conservação do patrimônio histórico e cultural levaria à seguinte situação: “o Estado deixaria de desempenhar um papel negativo, de apenas impor restrições à descaracterização, e passaria a articular projetos de desenvolvimento para as áreas a serem preservada/conservadas/revitalizadas" (BRASIL, 2005, p. 54-55).

Embora não haja um maior detalhamento sobre o que o Governo Federal entende por "projetos de desenvolvimento para áreas preservadas", pode-se supor que a idéia em pauta é criar meios para que o patrimônio histórico e cultural das cidades não permaneça imobilizado. Dito de outra maneira, impedir que o patrimônio histórico e cultural não esteja condicionado a normas rígidas que inviabilizem a sua transformação, ou seu uso, para fins de atividades turísticas e de consumo cultural. Atividades essas que seriam capazes de gerar novas receitas para os municípios, bem como novas 
possibilidades de negócios e lucros para os setores privados que se beneficiam diretamente desta liberalização do patrimônio.

No tocante a questão das políticas patrimoniais, é sintomática a parecença entre o discurso do Governo Federal e aquele próprio aos agentes privados - como a Associação Viva o Centro. Ambos defendem, ideologicamente, a transformação do uso do espaço nos centros históricos como forma de fomentar uma nova dinâmica econômica nesta região ${ }^{111}$. Esta dinâmica se traduziria em valorização imobiliária para os proprietários de imóveis localizados nas áreas de reabilitação urbana, bem como propiciaria ganhos ao diversos setores que se beneficiam do consumo neste/deste espaço.

Esta mesma lógica que defende a liberalização do patrimônio histórico e induz a valorização do solo tem sido aquela que nega o uso e apropriação do espaço pelas classes populares, empurrando-as para as áreas periféricas. Esta lógica produz os mesmos efeitos que, ambiguamente, tanto o Governo Federal - ao promulgar o Estatuto da Cidade - como o poder público municipal - ao reiterar os instrumentos normativos do Estatuto, por meio da elaboração do Plano Diretor - esperam combater.

\subsection{O estado atual das coisas: o estatuto permanece como possibilidade}

Ainda que no ano de 2002 a prefeitura de São Paulo tenha aprovado a Lei Municipal $\mathrm{n}^{\circ} 13.430 / 02$ - que institui o Plano Diretor Estratégico municipal - reiterando as diretrizes do Estatuto da Cidade, reafirmando como compromisso social a delimitação de uma política urbana voltada para o desenvolvimento das funções sociais da cidade e da propriedade urbana, muito pouco foi alcançado em termos de resultados efetivos.

Pode-se afirmar que, ao menos no caso de São Paulo, o Estatuto da Cidade permanece enquanto possibilidade. Ou seja, ainda que o poder público municipal tenha procurado cumprir as determinantes do Estatuto e construir uma política urbana para regulação do uso do solo, não houve um esforço posterior para a criação de leis específicas que regulamentassem os seus instrumentos jurídicos e tributários. São

\footnotetext{
111 A Associação Viva o Centro pronuncia que, como resultado do tombamento de patrimônio histórico no Centro Histórico de São Paulo, tanto a reforma de imóveis, como as mudanças urbanísticas na região precisarão ser submetidas ao órgão do poder público responsável por sua preservação. Tal fato pode comprometer o interesse das empresas em ali se instalar. (ASSOCIAÇÃO VIVA O CENTRO, 2005).
} 
justamente tais medidas aquelas que propiciariam o cumprimento da função social da propriedade urbana.

Há no plano diretor municipal de São Paulo a delimitação das propriedades que a princípio estariam sujeitas ao parcelamento, edificação e utilização compulsórios, mediante a identificação dos imóveis vazios ou subutilizados existentes em distintas regiões da cidade. Entretanto, a efetividade deste instrumento, que representaria a possibilidade de garantir a utilização dos imóveis que se encontram sem uso, estava sujeita à aprovação de uma lei específica que o regulamentasse, contudo, até o período recente isso não ocorreu.

Deste modo, em função da não regulamentação do instrumento legal sobre o parcelamento, edificação e utilização compulsórios da propriedade urbana, os demais instrumentos jurídicos e tributários que a ele estão vinculados também ficam proibidos de serem aplicados na cidade. Neste caso, tanto o IPTU progressivo no tempo quanto a desapropriação com pagamentos em títulos da dívida pública, que poderiam induzir ao cumprimento da função social da propriedade urbana, permanecem inaplicáveis ou, apenas, no campo das possibilidades futuras.

Por outro lado, nas diretrizes de uso e ocupação do solo, o Plano Diretor Estratégico regulamentou e delimitou Zonas Especiais de Interesse Social - ZEIS. Este instrumento, tal como consta no Plano Municipal de Habitação da Prefeitura de São Paulo, é considerado "o mais importante instrumento que o Plano Diretor criou visando o enfrentamento dos problemas habitacionais da cidade" ${ }^{\prime 12}$ (SÃO PAULO, 2003, p. 72). No Art. 171 do Plano Diretor, as Zonas Especiais de Interesse Social são definidas como:

[...] são porções do território destinadas, prioritariamente, à recuperação urbanística, à regularização fundiária e produção de Habitações de Interesse Social - HIS ou do Mercado Popular - HMP [...] incluindo a recuperação de imóveis degradados, a provisão de equipamentos sociais e culturais, espaços públicos, serviço e comércio de caráter local (Cap. 2, art. 171).

As Zonas Especiais de Interesse Social previstas no Plano Diretor de São Paulo são de quatro tipos e, de modo sintético, podem ser assim compreendidas: ZEIS 1 -

\footnotetext{
112 O Plano Municipal de Habitação ainda destaca que: "As ZEIS delimitadas pelo Plano Diretor [...] abrangem 140 milhões de metros quadrados representando cerca de $12 \%$ da área urbana da cidade. Desse total, 120 milhões correspondem a ZEIS 1, ou seja, a áreas já ocupadas por favelas e loteamentos precários. Considerando-se apenas as áreas das ZEIS 2 (terrenos e glebas vazias) e os terrenos vazios delimitados como ZEIS 3, estima-se que esteja garantida a destinação de terras para a construção de 130 mil unidades habitacionais de interesse social [...]" (SÃO PAULO, 2003, p. 74).
} 
áreas ocupadas por favelas e loteamentos precários, habitadas por população de baixa renda; ZEIS 2 - áreas com terrenos não edificados ou subutilizados; ZEIS 3 perímetros ou imóveis subutilizados/deteriorados, ocupados por cortiços e localizados em áreas dotadas de infra-estrutura; e ZEIS 4 - terrenos não edificados em áreas de proteção aos mananciais para o atendimento habitacional de famílias removidas de áreas de risco e de preservação permanente.

No caso de áreas com urbanização consolidada, tais como as áreas centrais da cidade que apresentem imóveis sem uso, subutilizados ou degradados; a partir da delimitação das Zonas Especiais de Interesse Social 3 se espera estimular o seu uso habitacional e constituir uma estratégia que beneficie a apropriação desses espaços pelas classes populares e classes médias. Do mesmo modo, o poder público pretende - ao menos, é isso o que a lei faz parecer - que as ZEIS se tornem um instrumento legal a partir do qual seja possível impedir a expulsão da população de baixa renda em virtude da valorização da área, como decorrência dos investimentos públicos.

De um modo mais abrangente, o Plano Diretor especifica que as Zonas Especiais de Interesse Social 3 compreendem:

[...] áreas com predominância de terrenos ou edificações subutilizados situados em áreas dotadas de infra-estrutura, serviços urbanos e empregos, ou que estejam recebendo investimentos desta natureza, onde haja interesse público expresso por meio desta lei, dos planos regionais ou da lei específica, em promover ou ampliar o uso por Habitação de Interesse Social - HIS ou do Mercado Popular - HMP, e melhorar as condições habitacionais da população moradora (Cap. 2, art. 171, inciso III).

De acordo com esses parâmetros, o Plano Diretor Estratégico de São Paulo delimitou e aprovou quinze ZEIS-3 na Subprefeitura Sé. Determinou também, que a aprovação de novos empreendimentos nesta zona (incluindo novas edificações e reforma de edifícios residenciais não ocupados ou subutilizados) está submetida à destinação mínima de $50 \%$ da área a ser construída ou reformada (em cada lote ou edificação) para a produção de Habitação de Interesse Social - HIS, conforme expresso no Art. 176, inciso III, alínea "e"113. Neste caso, entende-se que Habitação de Interesse Social destina-se exclusivamente a famílias com renda de até seis salários mínimos.

Portanto, a estratégia em questão tem como finalidade proporcionar o uso de áreas ociosas da cidade e estimulá-lo por meio de sua ocupação habitacional. Entretanto,

\footnotetext{
${ }^{113}$ Estão dispensados dessa exigência os lotes regulares que apresentam área igual ou inferior a $500 \mathrm{~m}^{2} \mathrm{na}$ data da aprovação da lei.
} 
este processo não se efetivou sem conflitos e contradições. Conforme já foi apontado anteriormente, as ZEIS aprovadas pelo Plano Diretor Estratégico de São Paulo estão delimitadas em sua maior parte fora dos distritos Sé e República que, por sua vez, constituem as áreas em que se concentraram um elevado número de imóveis vazios. Esta delimitação propiciou um questionamento por parte dos movimentos sociais, que passaram a sugerir a delimitação de novas ZEIS dentro desses distritos.

No que diz respeito às contradições em relação à delimitação de ZEIS-3 no Centro de São Paulo, torna-se necessário enfatizar a atual proposta do poder público municipal para a produção de habitações na área da intervenção do chamado projeto "Requalificação Urbana Nova Luz""114.

Como já foi possível analisar em momentos anteriores, as estratégias delimitadas pelo poder público visando a revalorização de trechos do bairro Santa Ifigênia (Distrito República), na região popularmente conhecida por Cracolândia, têm se efetivado a partir da ação policial e judicial - para a remoção da população marginalizada e mudança do perfil sócio-econômico da região -, e pela interdição de estabelecimentos comerciais considerados ilegais, etc. Ao mesmo tempo, a prefeitura municipal já estabeleceu o limite da área da ser desapropriada. Esta desapropriação tem como finalidade criar novas áreas para a construção de empreendimentos a serem utilizados na realização de atividades econômicas e para o uso habitacional.

No entanto, na área de intervenção do projeto "Requalificação Urbana da Nova Luz” está compreendido em uma Zona Especial de Interesse Social 3 (ZEIS 3-C016). Neste caso, segundo determina o Art. 140 da Lei de Zoneamento (Lei n 13.885/04) "a aprovação de nova edificação ou reforma de edificação existente deverá observar a destinação de $80 \%$ da área construída computável final para habitações de interesse social - HIS - e habitações de mercado popular - HMP, garantindo-se o mínimo de $40 \%$ para HIS" (SÃO PAULO, 2006a, p. 1).

Tal como expresso no documento "Requalificação Urbana da Nova Luz: a proposta de produção de habitações na área de intervenção" (SÃO PAULO, 2006a), o poder público avalia que as intervenções a serem realizadas nesta região não trarão consequiências para permanência da população de baixa renda que vive nos cortiços aí

\footnotetext{
114 Cabe enfatizar que não se pretende fazer nesta pesquisa um estudo de caso, ou uma análise aprofundada, do projeto "Requalificação Urbana Nova Luz", mas sim considerar um tópico específico deste projeto que é revelador da maneira como o poder público tem conduzido a aplicação recente de um instrumento urbanístico (as ZEIS 3) do Estatuto da Cidade no Centro Histórico de São Paulo.
} 
existentes. Aponta-se que "as ações de reabilitação de edificações encortiçadas e a produção pública de novas unidades habitacionais obrigatoriamente beneficiarão os atuais ocupantes dessas moradias" (SÃO PAULO, 2006a, p. 1-2). Esta afirmação do poder público procura reiterar o Parágrafo $3^{\circ}$, do Artigo 140 da Lei de Zoneamento, que dispõe: "no caso de demolição de edificação usada como cortiço, as HIS produzidas [...] deverão ser destinadas prioritariamente à população que morava no imóvel" (SÃO PAULO, 2006a, p. 1).

A elaboração da proposta habitacional do projeto de "Requalificação Urbana Nova Luz" tomou como critério os dados sobre o rendimento médio nominal mensal da pessoa responsável pelo domicílio nos distritos do município de São Paulo, produzidos pelo IBGE, a partir do Censo Demográfico realizado em 2000. Estes dados foram utilizados para apontar que, diante de um quadro onde a maior parcela dos domicílios do Distrito República se enquadra nas faixas de rendimentos de até 5 salários mínimos (35,14\% dos domicílios) e de 5 a 15 salários mínimos (44,20\% dos domicílios), a revalorização do bairro Santa Ifigênia não resultará na alteração do perfil econômico da sua população. Procura-se aferir, portanto, que o rendimento médio mensal desta população (ou dos domicílios existentes) coincide com as classes de rendimentos dos programas de produção de habitação de interesse social (HIS) e de mercado popular (HMP) previstos para as ZEIS-3. (SÃO PAULO, 2006a). Deste modo o poder público afirma:

Desta forma as disposições da ZEIS-3 Santa Ifigênia que gravam parte da área de projeto em nada conflitam com a proposta de sua requalificação; antes disso, asseguram o incremento do uso habitacional na região, tão necessário à garantia da vitalidade da área fora do horário comercial. E, no mesmo sentido, revelam compatibilidade com o rendimento médio da população residente na área central (SÃO PAULO, 2006a, p. 3).

Entretanto, a partir da análise dos documentos da "Operação Tripartite CAIXA/CDHU/PMSP: Área Central Nova Luz" (SÃO PAULO, 2006b), em que são divulgados os parâmetros para a realização de empreendimentos habitacionais na Santa Ifigênia, foi possível observar que o projeto habitacional a ser implementado nesta região procura, de um lado, viabilizar recursos para produzir moradias que atendam as classes da população com rendimentos entre 3 e 10 salários mínimos e, do outro lado, criar incentivos financeiros para efetivar a remoção da população mais pobre, cujo rendimento é inferior a 3 salários mínimos. 
A chamada "Operação Tripartite CAIXA/CDHU/PMSP" é resultado de uma parceria entre os órgãos do Governo Federal (Caixa Econômica Federal - CAIXA), Prefeitura do Município de São Paulo (Companhia Metropolitana de Habitação de São Paulo - COHAB) e Governo do Estado de São Paulo (Companhia de Desenvolvimento Habitacional e Urbano do Estado de São Paulo - CDHU), para a realização de empreendimentos/operações habitacionais na Nova Luz.

Os empreendimentos a serem realizados terão recursos oriundos das três esferas de governo e possuem como referência os programas habitacionais operados pela Caixa Econômica Federal: Programa Carta de Crédito/Operações Coletivas/FGTS, Programa Carta de Crédito Associativo/FGTS e Programa de Arrendamento Residencial (PAR). A partir da implementação desses programas, tendo como complemento os recursos a serem disponibilizados pela $\mathrm{COHAB}$ e pelo $\mathrm{CDHU}^{115}$, a parceria prevê o atendimento de famílias com renda entre 1 e 10 salários mínimos (SÃO PAULO, 2006b).

Embora seja previsto o atendimento habitacional à população de baixa renda, as propostas apresentadas na Operação Tripartite indicam que tal atendimento não ocorrerá na área de intervenção do programa de "Requalificação Urbana da Nova Luz". Sendo assim, mediante a concessão da Carta de Crédito no valor máximo de $\mathrm{R} \$ 30 \mathrm{mil}$, para famílias com rendimento até 3 salários mínimos, o poder público fará com que esta população seja removida da região e passe a procurar moradia em áreas cujo preço do imóvel é menos elevado. Tal como consta no documento "Operação Tripartite CAIXA/CDHU/PMSP: Área Central Nova Luz" - pela implementação do Programa Carta de Crédito/Operações Coletivas/FGTS na modalidade aquisição de imóveis usados - o poder público indica que: "Estas operações poderão ser utilizadas como suporte ao Programa de Intervenção na Área Nova Luz, para remoção de famílias com rendimento mensal entre 1,00 e 3,00 salários mínimos, com a oferta de 100 cartas de crédito para aquisição de imóveis usados" (SÃO PAULO, 2006b, p. 4, grifos nossos).

Por outro lado, a partir da concessão de Carta de Crédito no valor máximo de R \$ 80 mil para famílias com rendimento entre 3 e 10 salários mínimos - por meio da implementação do Programa Carta de Crédito Associativo/FGTS - o poder público

\footnotetext{
${ }^{115}$ A parceria prevê que a CDHU ofereça contrapartida financeira para complementar os investimentos da CAIXA, visando atingir o valor total dos imóveis a serem adquiridos, tendo em vista que os limites fixados em cada um dos programas operados por este banco ficam abaixo da avaliação do preço dos imóveis da região. Já a contrapartida da prefeitura/COHAB se daria por meio da doação de terrenos e por garantir uma "verba de atendimento social" de até R\$ 5 mil para suporte ao atendimento dos beneficiários.
} 
reconhece que: "Esta operação poderá ser utilizada para ofertar a alternativa de aquisição de 170 unidades habitacionais novas às famílias com rendimento mensal entre 3,01 e 10,00 salários mínimos, na Área Nova Luz" (SÃO PAULO, 2006b, p. 5, grifos do autor).

Já no caso do Programa de Arrendamento Residencial (PAR), o poder público identifica que o limite máximo de valor de avaliação do imóvel deste programa, que é de R\$ 34 mil a 40 mil reais ${ }^{116}$, "não atendem a realidade de São Paulo, cujo valor de imóvel é mais elevado, por força dos custos de terrenos" (SÃO PALO, 2006b, p. 2). Neste caso, a Operação Tripartite passa a prever a realização de "excepcionalidades" a serem promovidas pela CAIXA de modo a viabilizar a parceria de recursos. Tal operação se realizará a partir da ampliação do limite de avaliação do imóvel previsto no PAR para R \$ 80 mil. Neste caso, a diferença entre o valor de avaliação da CAIXA e o de aquisição do imóvel será pago com contrapartida da CDHU. Sendo assim, "esta operação poderá ser utilizada para ofertar unidades habitacionais novas, em arrendamento, às famílias com rendimento mensal entre 3,01 e 6,01 salários mínimos, na Área Nova Luz" (SÃO PAULO, 2006b, p. 6).

O que se pretende apontar a partir da análise desses documentos é que, embora as ZEIS tenham sido regulamentadas pelo poder público no Plano Diretor Estratégico no âmbito de uma política que visasse a reversão da tendência de expulsão da população de baixa renda para as periferias da cidade, foi possível constatar que esta tendência tem sido reiterada nos planos de intervenção do poder público em áreas de infra-estrutura consolidada da cidade, como é o caso da Nova Luz.

O Plano Diretor de São Paulo determina que as ZEIS 3 sejam áreas prioritárias para a produção de habitação de interesse social, portanto, induzam a permanência das famílias de baixo poder aquisitivo (com renda de até 6 salários mínimos), pela reforma ou produção de novas moradias em áreas de infra-estrutura instalada e onde existam edificações subutilizadas. Contudo, o critério adotado pelo poder público - no caso da região da Santa Ifigênia - tem sido o de selecionar dentre esta população as famílias das classes populares que se enquadram nas faixas de "maior rendimento" (de 3 a 6 salários mínimos) para lhes prover condições de morar no centro da cidade. Esta mesma medida procura, também, beneficiar uma parte da classe média (população que apresenta

\footnotetext{
${ }^{116}$ Neste caso, R\$ 34 mil para unidades habitacionais com acabamento básico e R\$ 40 mil para unidades habitacionais com acabamento superior.
} 
rendimentos entre 6 e 10 salários mínimos) às quais será "ofertada" a aquisição de novas unidades habitacionais da Nova Luz.

Contrariamente ao que prevê o poder público, o projeto de "Requalificação Urbana da Nova Luz" acarretará numa mudança do perfil social e econômico da população que já habita o Distrito República. Esta afirmação pode ser justificada pela observação de que há efetivamente uma estratégia de remoção da população mais pobre a ser incentivada por meio da concessão de paliativos financeiros que, ao encontro da própria avaliação feita pelo poder público sobre o preço dos imóveis existentes na Nova Luz, são insuficientes para a aquisição de novas moradias nesta mesma região.

Esta análise permite aferir que, embora exista na cidade de São Paulo uma política urbana centrada em uma legislação urbanística que aponta para um ideal de produção de cidades mais justas, democráticas, compatíveis com o interesse social (que referendam as diretrizes e instrumentos políticos e jurídicos do Estatuto da Cidade), estes ideais restritos ao campo do discurso. Ou seja, na prática as estratégias delimitadas pelo poder público têm reiterado a produção do espaço como condição para a sua apropriação privada por segmentos específicos da sociedade, geralmente pelas classes médias e de maior poder aquisitivo, em detrimento da parcela restante da população.

Deve-se observar que quando o poder público regulamenta - por meio do Plano Diretor - um instrumento urbanístico como as ZEIS, ele o faz porque reconhece, ao menos em tese, um dos principais problemas urbanos de São Paulo: a existência de áreas plenamente urbanizadas da cidade mantidas em desuso e à espera de valorização imobiliária. Tais áreas, contudo, poderiam se constituir em alternativas para suprir parte da demanda por habitação feita pela população de baixa renda (por meio da produção de HIS), bem como pelas famílias de renda média (por meio da produção de HMP) ${ }^{117}$. Entretanto, é necessário considerar que este reconhecimento não tem se convertido, necessariamente, em ações para o enfrentamento do respectivo problema. Pelo contrário, a prática que tende a ser adotada articula a remoção da população mais pobre e a atração da população com maior poder aquisitivo para o Centro da cidade.

Sendo assim, tendo como premissa a efetivação de uma política urbana pretensamente geradora de inclusão social e partindo de uma interpretação muito particular da lei existente (ou do seu uso distorcido), o poder público municipal de São

\footnotetext{
$117 \mathrm{O}$ reconhecimento deste problema certamente está atrelado à pressão dos movimentos sociais de moradia que, continuamente, cobram do poder público políticas de intervenção nas propriedades deixadas vazias ou sem uso no Centro da cidade, visando a produção de novas habitações.
} 
Paulo planeja efetivar uma ZEIS-3 no Centro da cidade (no bairro Santa Ifigênia/distrito República), combinando remoção da população pobre, o atendimento parcial às classes de 3 a 6 salários mínimos e a atração das classes médias.

A análise aqui construída considera que, em função do caráter recente do Estatuto da Cidade e do Plano Diretor Estratégico de São Paulo, talvez seja cedo para fazer uma avaliação mais precisa sobre os efeitos que essas políticas podem trazer em termos da produção do espaço na cidade de São Paulo. De todo modo, a partir do que foi possível observar até agora, as premissas que estão presentes no Estatuto, e que procuram estabelecer novos parâmetros para o uso e ocupação do solo nas cidades brasileiras (mediante o cumprimento da função social da cidade e propriedade urbana em prol do interesse coletivo), ainda se enquadram no campo das contingências e possibilidades futuras (porque não houve a regulamentação nos municípios da totalidade dos instrumentos urbanísticos contidos no Estatuto ${ }^{118}$ ) ou, até mesmo, são tomadas para dar conteúdo a discursos falaciosos e a práticas políticas de fundo escuso.

O ideal de política urbana que o Estatuto da Cidade procura defender tem se mostrado bem diverso daquilo que se efetiva na prática nas cidades brasileiras. Isso porque as diretrizes e os instrumentos do Estatuto da Cidade não conseguem anular a força dos interesses existentes nas cidades brasileiras. Tal fato coloca em xeque a real potencialidade do Estatuto em propiciar uma mudança significativa no atual quadro urbano brasileiro.

À exemplo da situação ora analisada, observou-se que o próprio poder público mesmo que enquadrando a sua ação nos limites formais da lei - assume uma prática de caráter exclusivista, cujo efeito tende a beneficiar, dentre as classes populares, aquelas de maior poder aquisitivo sociedade, colocando um limite claro a uma política urbana que pretende "o desenvolvimento das funções sociais da cidade e da propriedade" e que pretensamente se estabelece "em prol do bem coletivo".

O atual estado das coisas pode representar "um balde de água fria" em relação às intenções dos movimentos sociais que vislumbravam no Estatuto da Cidade a garantia aos direitos relativos à moradia, ao acesso à infra-estrutura urbana e ao cumprimento da função social da propriedade, etc. Ainda que essas conquistas não tenham se confirmado, a promulgação do Estatuto permitiu, por outro lado, estabelecer um novo patamar para negociação e embate entre os movimentos sociais e o poder público.

\footnotetext{
${ }^{118}$ Neste caso, a referência que se faz é específica para o caso do município de São Paulo.
} 
O que se pretende afirmar é que, independentemente da regulamentação dos instrumentos urbanísticos do Estatuto da Cidade, a sanção desta lei possibilitou aos movimentos sociais urbanos garantir alguma legitimidade às suas reivindicações. Isso porque a lei incorporou, portanto passou a reconhecer como legal, parte das diretrizes para reforma urbana reivindicadas pelos próprios movimentos sociais. Neste caso, a exemplo do que ocorre hoje no Fórum Centro Vivo, os movimentos e entidades sociais que o integram procuram amparar suas reivindicações ao cumprimento das determinantes legais contidas no Estatuto.

Pode-se apontar que, se de um lado a sanção do Estatuto da Cidade propiciou a abertura de um novo horizonte para a discussão dos problemas urbanos - de modo a possibilitar aos movimentos sociais inscrever as suas reivindicações no quadro dos direitos legais -; de outro lado, devido ao caráter ainda contingente dessa legislação urbana, ou do seu uso segundo finalidades diversas, os movimentos sociais continuam a pressionar o Estado para a plena efetivação das diretrizes e instrumentos do Estatuto.

Deste modo, os movimentos sociais mantêm a sua mobilização em defesa da regulamentação da política urbana preconizada no Estatuto da Cidade. Este fato fica evidenciado na fala de Evaniza Rodrigues ${ }^{119}$ - quando se referiu às questões ligadas ao direito urbanístico e enfatizou os limitados efeitos da aprovação do Plano Diretor de São Paulo - a qual defende que um grande passo a ser dado pelos movimentos sociais é “fazer tudo que já existe entrar em funcionamento". Tal afirmação permite constatar que os movimentos sociais ainda depositam no efetivo cumprimento da legislação urbanística uma esperança para fazer valer os direitos considerados fundamentais para o alcance da justiça social e do direito à cidade.

\footnotetext{
${ }^{119}$ Fala proferida no IV Congresso Brasileiro de Direito Urbanístico, realizado em São Paulo no período de 5 a 6 de dezembro de 2006.
} 


\section{œ Considerações Finais}

A partir dos anos 1990, intensifica-se um processo de transformação do Centro Histórico de São Paulo que tem como premissa a produção de uma nova valorização do espaço. Como resultado das estratégias do poder público municipal, as intervenções realizadas na região central trazem, imediatamente, implicações sobre o uso e a apropriação deste espaço, principalmente no que diz respeito à permanência da população de mais baixa renda.

Pode-se afirmar que, mediante este processo de revalorização, os agentes econômicos da cidade - o mercado imobiliário e também os chamados setores de serviços, turismo, etc. - passam a encontrar possibilidades vantajosas (lucrativas) para intensificar os seus investimentos no Centro. Assim, na medida em que o espaço é transformado para melhor se adequar às necessidades de reprodução do capital desses agentes, modifica-se a sua forma de uso e apropriação pela população da cidade. $\mathrm{O}$ uso do espaço se torna cada vez mais atrelado às possibilidades individuais de consumo dos cidadãos, à seletividade imposta pelo mercado e ao controle e vigilância que coíbem os chamados usos inadequados.

Deste modo, à medida que o Centro vai se tornando valorizado - pela primazia do seu valor de troca - limites passam a ser impostos à sua apropriação, levando ao declínio do seu valor de uso.

Embora o Centro Histórico da cidade de São Paulo ainda seja nos dias de hoje um espaço onde convivem cotidianamente os pobres, as classes de médias e aquelas de maior rendimento da sociedade ${ }^{120}$, a tendência mormente enfatizada nas estratégias para a sua revalorização parece evidenciar que continuará a restar aos mais pobres o caminho em direção à periferia da cidade.

Buscando compreender os problemas relacionados à habitação no Centro Histórico de São Paulo, no seu contexto de revalorização, a partir da análise realizada, é possível considerar que as estratégias para reforço da função moradia na região central tendem a enfatizar a apropriação deste espaço por outra camada da população, que não a de baixa renda. Como evidência para tal constatação, pode-se mencionar uma estratégia do poder público municipal que, baseada na remoção dos mais pobres, procura estimular um adensamento populacional do Centro da cidade pela atração de classes

\footnotetext{
${ }^{120} \mathrm{O}$ que não supõe, necessariamente, uma convivência harmônica.
} 
médias. Eis aqui uma evidência para compreender que há em curso um processo de gentrification.

À esteira dos novos investimentos da Prefeitura de São Paulo - para a melhoria da infra-estrutura, vigilância/monitoramento do espaço público e aumento do efetivo policial para atuação repressiva contra os moradores de rua e comerciantes ambulantes do Centro Histórico da cidade - se observa um novo dinamismo do mercado imobiliário na região que, mediante a construção de novos edifícios e a reforma de imóveis antigos, volta-se para a produção de moradias para outra população que se quer atrair.

Associado a este recente dinamismo do mercado imobiliário se constata, também, uma elevação do valor do aluguel na região central, que pode estar vinculada a um movimento de valorização do preço do solo. Este fato certamente significará um encarecimento do custo de vida no Centro e, como conseqüência, poderá implicar na saída das classes populares.

Conforme foi possível analisar nesta Dissertação, embora em alguns momentos o poder público anteveja que a revalorização do Centro Histórico pode resultar em tal consequiência, muito pouco foi feito no sentido de conter este efeito. A revalorização permanece como processo inexorável, já o seu impacto perverso sobre o uso e apropriação do espaço pelas classes populares foi parcialmente considerado apenas nas gestões municipais de cunho progressista: Luiza Erundina e Marta Suplicy.

As duas gestões mencionadas procuraram delimitar políticas de habitação para a população de baixa renda no Centro de São Paulo. E neste processo foi imprescindível a pressão dos movimentos sociais que passaram a cobrar do poder público o direito à habitação na região central, tendo em vista o levado número de imóveis vagos aí existentes e o crescente déficit habitacional da cidade ${ }^{121}$.

Ainda que as políticas voltadas para o atendimento habitacional às classes populares não tenham sido extensivas ou abarcado toda a dimensão do problema existente $^{122}$, no momento em que foram elaboradas constituíram alguma possibilidade de permanência desta população no Centro. Por outro lado, pôde-se aferir que nas gestões municipais mais conservadoras, os problemas relacionados à habitação na região central pela população de baixa renda sequer receberam um tratamento no conjunto das políticas elaboradas.

\footnotetext{
${ }^{121}$ A análise considera, com maior ênfase, os processos ocorridos na gestão Marta Suplicy.

${ }^{122} \mathrm{O}$ que seria algo, certamente, inviável dada à amplitude e complexidade do problema habitacional existente não só no Centro, mas na cidade como um todo.
} 
É possível considerar, também, que na atual gestão do prefeito Gilberto Kassab, a remoção da população de baixa renda se constitui como um plano estratégico para a revalorização do Centro Histórico. Deste modo, o poder público passa a afirmar, sem comiseração, que a habitação nesta região deve se destinar, prioritariamente, às classes de renda média ou aos setores sociais que "consomem e geram empregos"123.

Ainda no que se refere à análise das gestões municipais entre 1991-2006, percebe-se uma reiteração das estratégias que visam à revalorização do Centro da cidade. A permanência dessa pauta nas diferentes gestões revela a força política dos agentes da sociedade civil que organizam suas demandas e atuações em torno da valorização do espaço. No entanto, esse processo encontra barreiras à sua plena efetividade por conta dos usos e apropriações existentes na região - tais como, moradores de rua, população de cortiços e camelôs - os quais se procura "sanear" ou afastar do Centro.

Ao longo da investigação realizada, percebeu-se que o discurso manifestado pelo poder público procura conceber o reforço da função habitacional no Centro Histórico como um dos elementos imprescindíveis para a sua revalorização. Com isso, espera-se que os (novos) moradores possam promover um maior aproveitamento dos equipamentos urbanos e dos serviços públicos lá existentes, bem como recuperar e colocar em uso os imóveis abandonados do Centro da cidade, barrando o seu processo de deterioração/desvalorização.

Somadas às intenções já mencionadas, o poder público passa a divulgar que o uso habitacional do Centro deve contemplar a diversidade dos seus habitantes, ou seja, deve se constituir pela presença de população com diferentes perfis sociais e econômicos. Entretanto, tal como se enfatizou no presente trabalho, é necessário questionar aquilo que se nomeia por "diversidade" nas estratégias para revalorização do Centro, isso porque as práticas efetivadas parecem indicar limites à convivência neste espaço entre as classes sociais mais pobres e aquelas de maior rendimento.

Neste ponto, cabe assinalar que a idéia de um "uso socialmente diversificado" da região central tem sido defendida pela Associação Viva o Centro. No entanto, esta idéia tem pouco a ver com uma mistura de classes, parecendo antes denotar um discurso que, na defesa dos anseios dos proprietários de imóveis e/ou do setor imobiliário, procura anunciar o interesse desses agentes em intensificar a ocupação do Centro pelas classes

\footnotetext{
${ }^{123}$ Remete-se aqui a fala do atual Secretário Municipal da Habitação, Orlando de Almeida Filho.
} 
de maior poder aquisitivo. Ao mesmo tempo, esse discurso expressa o temor de que o poder público possa em algum momento destinar o uso do Centro, prioritariamente, para habitação das classes de mais baixo rendimento.

Sendo assim, é relevante retomar que a Associação Viva o Centro defende o reforço habitacional do Centro Histórico de São Paulo, porém, como um elemento gerador de mudança no perfil social da região. Do mesmo modo, a Associação entende que a primazia da ocupação popular do Centro pode levar a uma desvalorização ainda maior do patrimônio imobiliário ali existente. Neste sentido, falar em "diversidade" seria uma forma de colocar em relevo as demandas das classes de maior rendimento, o que se faria em detrimento do uso e apropriação deste espaço pelas classes populares.

A Associação Viva o Centro tem procurado, desde o início da década de 1990, pressionar o poder público pelo atendimento às demandas específicas que representa, dentre as quais, a valorização imobiliária da região central. Conforme a análise desenvolvida, é por meio de sua participação nas instâncias de decisão do poder público que a Viva o Centro encontra uma brecha para pautar, por meio do discurso que elabora, algumas das estratégias de intervenção do Estado no Centro Histórico de São Paulo.

Compete ao discurso ideológico desta Associação a construção de uma representação do espaço que passou a conceber o Centro como o "território fecundo da cidade", em oposição à idéia de lugar deteriorado ou degradado. O discurso em questão passa a sugerir que esta centralidade se constitui como um dos lugares estratégicos da metrópole para a sua conexão à rede de cidades mundiais, bastando para isso uma maior qualificação e ordenação do seu uso. Em suma, delineia-se uma estratégia que pretende cooptar o poder público para a revalorização do Centro Histórico e espera-se, por meio deste processo, que sejam materializadas novas intervenções e investimentos na região, de modo a propiciar tanto a valorização patrimonial desejada, quanto a transformação deste espaço. Neste sentido, transformá-lo é um modo torná-lo mais adequado aos interesses dos agentes econômicos que buscam se apropriar do espaço como condição para a reprodução do seu capital.

Deve-se considerar, entretanto, que resistências se impõem ao processo de revalorização do Centro Histórico de São Paulo. Esta oposição está expressa nas reivindicações dos movimentos sociais - aqui representados pelo Fórum Centro Vivo que demandam por políticas públicas que propiciem o direito à moradia e à permanência da população de baixa renda na região central. 
Mediante a investigação das ações do Fórum Centro Vivo e a análise das suas premissas foi possível identificar que os interesses manifestos pelos movimentos e entidades sociais nele articulados, apontam para outras possibilidades de uso e apropriação do espaço que conflitam com os interesses representados pela Associação Viva o Centro.

O próprio nome dessas duas instituições da sociedade civil é revelador das divergências em torno do uso e apropriação do Centro de São Paulo. Enquanto a Associação Viva o Centro veicula em seu nome um apelo de retorno à vida que agonizaria nesta parte da cidade, ou ainda, dá "vivas" ou "salvas" a esse lugar; o Fórum Centro Vivo reafirma que este espaço é muito vivo e ocupado, justamente, por essa população que a Associação quer expulsar.

Na perspectiva do Fórum Centro Vivo, o Centro da cidade deve ser o "o lugar do povo" e, portanto, um espaço privilegiado para moradia, trabalho e lazer das classes populares. A revalorização da região central é denunciada como um processo que tem como primazia a afirmação dos direitos individuais sobre os direitos coletivos, assim como a defesa dos interesses econômicos e da valorização imobiliária, ao mesmo tempo em que induz à expulsão e segregação sócio-espacial da população mais vulnerável (moradores de rua e cortiços, trabalhadores ambulantes, catadores de material reciclável, etc).

Na contramão do discurso da Associação Viva o Centro - centrado na ideologia de um Centro forte e eficiente -, o Fórum Centro Vivo busca pautar o poder público com as suas reivindicações por justiça social e pela defesa de uma cidade democrática. Estas reivindicações retomam as diretrizes para política urbana presentes no Estatuto da Cidade, com ênfase para os aspectos que enunciam a função social da propriedade urbana e da cidade e a sua gestão democrática. Deste modo, os movimentos e entidades sociais articulados no Fórum Centro Vivo, procuram centrar as suas demandas em torno do cumprimento de direitos que estão estabelecidos formalmente e que, ao menos em tese, apontam para uma outra possibilidade de produção da cidade que não seja pela manutenção especulativa de espaços vazios nas áreas centrais e pela imposição da segregação sócio-espacial à população de baixa renda.

Contudo, no que concerne aos direitos previstos no Estatuto da Cidade, já é possível assinalar que, ao menos para o caso de São Paulo, foram limitados os avanços em relação à sua regulamentação e plena efetividade. Isso parece evidenciar que as mesmas forças políticas e econômicas - que tendem a se apropriar privadamente do 
espaço e traçam estratégias para valorizá-lo - continuam a fazer prevalecer os seus interesses acima de quaisquer outros que possam ser reivindicados.

Ainda no que se refere ao Estatuto da Cidade, as conquistas e direitos almejados pelos movimentos sociais e que poderiam - ao menos como possibilidade - advir da regulamentação das diretrizes e instrumentos nele previstos ficam em suspenso. Isso porque as normas para regulação do uso do solo e cumprimento da função social da cidade e da propriedade urbana contidas no Estatuto estão marcadas por uma contingência (permanecem no campo das possibilidades) frente aos embates políticos/sociais que continuam a se estabelecer em torno da sua efetivação, ou ainda, porque inspiram outras práticas que determinam distintas finalidades para a sua operação.

Portanto, a luta dos movimentos sociais se mantém pelo embate travado cotidianamente com o poder público e com os demais agentes hegemônicos da cidade, e se estabelece como conflito pelo uso e apropriação do espaço. No caso específico que esta Dissertação procurou analisar, é possível considerar que, mediante a revalorização do Centro Histórico de São Paulo, o poder público - afinado aos interesses dos agentes privados (mobilizados pela Associação Viva o Centro) -, passa a reafirmar, pela lógica da reprodução do capital, a produção de um espaço para apropriação privada pelos agentes que visam à ampliação dos seus investimentos e lucros na região central da cidade. O Centro, assim concebido, tende a se tornar produto de consumo para as camadas mais abastadas, ao passo em que progressivamente declina como espaço de reprodução da vida das camadas de mais baixo rendimento da sociedade.

Por fim, cabe pontuar que, embora se reconheça a existência de diversos trabalhos, em diferentes áreas do conhecimento, que tomaram as transformações ocorridas no Centro Histórico de São Paulo nas últimas décadas, o esforço desta pesquisa foi o de centrar-se em um período histórico que permitisse, ao mesmo tempo, analisar documentos e ações desenvolvidas por gestões de cunho progressista e conservador, assim como o rebatimento público do mais importante marco legal para esta discussão, o Estatuto da Cidade. Além disso, a pesquisa selecionou dois agentes que vem ganhando destaque no cenário paulistano e que representam interesses de grupos situados em posições díspares na pirâmide social. 


\section{os BIBLIOGRAFIA}

ALVES, Glória da Anunciação. Paisagens metropolitanas, 2004. In: CARLOS, Ana Fani Alessandri \& OLIVEIRA, Ariovaldo Umbelino. Geografias de São Paulo: a metrópole do século XXI. São Paulo: Contexto, 2004. p. 285-306.

- O uso do centro da cidade de São Paulo e sua possibilidade de apropriação. Tese (Doutorado em Geografia). Departamento de Geografia. Faculdade Filosofia, Letras e Ciências Humanas, Universidade de São Paulo. São Paulo, 1999.

- As centralidades da cidade de São Paulo: o papel do Centro Tradicional. In: Anais do Simpósio de Geografia Urbana. Manaus, 2005.

ALMEIDA, Marco. Prefácio. In: ALMEIDA, Marco (org.). Os centros das metrópoles: reflexões e propostas para a cidade democrática do século XXI. São Paulo: Ed. Terceiro Nome/Viva o Centro/Imprensa Oficial do Estado, 2001.

ARANTES, Otília. Uma estratégia fatal: a cultura nas novas gestões urbanas. In: ARANTES, O., VAINER, C. \& MARICATO, E. A cidade do pensamento único: desmanchando consensos. Petrópolis: Vozes, 2000, p. 11-74.

ARANTES, Otília. Urbanismo em fim de linha e outros estudos sobre o colapso da modernização arquitetônica. São Paulo: Edusp, 2001.

ASCHER, François. Metropolização e transformação dos centros das cidades. In: ALMEIDA, Marco (org.). Os centros das metrópoles: reflexões e propostas para a cidade democrática do século XXI. São Paulo: Ed. Terceiro Nome/Viva o Centro/Imprensa Oficial do Estado, 2001. p. 59-67.

ASSOCIAÇÃO VIVA O CENTRO. Associação Viva o Centro: origem, forma e estrutura. Disponível em: <http://www.vivaocentro.org.br>. Acessado em: agosto de 2006.

- Viva o Centro e Ações Locais: 10 perguntas e respostas. São Paulo: Associação Viva o Centro, 2005.

Como uma Ação Local pode valorizar o seu endereço no Centro. São Paulo: Associação Viva o Centro, 2005.

maio de 2005.

Estatuto. Disponível em: <http://www.vivaocentro.org.br>. Acessado em:

. Publicações. Disponível em: <http://www.vivaocentro.org.br>. Acessado em: novembro de 2006.

Preparando o terreno para a iniciativa privada. URBS, São Paulo, $\mathrm{n}^{\circ} 38$, [sem paginação], 2005.

Carta aos Candidatos. São Paulo: Associação Viva o Centro, 2004. 
Habitação no centro. URBS, São Paulo, nº 34, [sem paginação], 2004.

2003.

. O centro que a cidade quer. URBS, São Paulo, n 29, [sem paginação],

. Estratégia de requalificação ou política habitacional. URBS, São Paulo, $\mathrm{n}^{\circ}$ 26, [sem paginação], 2002.

A década em que São Paulo reencontrou o Centro. URBS, São Paulo, $n^{\circ} 23$, [sem paginação], 2001.

. Uma ong para o centro. URBS, São Paulo, nº 2, [sem paginação], 1997.

- Associação Viva o Centro: propostas e compromissos. São Paulo: Associação Viva o Centro, 1996.

BIDOU-ZACHARIASEN, Catherine. Introdução. De volta à cidade: os processos de gentrificação às políticas de "revitalização" dos centros urbanos. São Paulo: Annablume, 2006.

BOMFIM, Valéria Cusinato. Os Espaços edificados vazios na área central da cidade de São Paulo e a dinâmica urbana. Dissertação (Mestrado em Engenharia Civil). Escola Politécnica. Universidade de São Paulo, São Paulo, 2004. v. 1.

BONDUKI, Nabil. Habitar São Paulo: reflexões sobre a gestão urbana. São Paulo: Estação Liberdade, 2000.

. Estatuto da Cidadade. Folha de São Paulo, São Paulo, 19. jul. 2001.

CARLOS, Ana Fani Alessandri. O espaço urbano: novos escritos sobre a cidade. São Paulo: Contexto, 2004.

A questão da habitação na metrópole de São Paulo. Revista Eletrônica de Geografia y Ciências Sociales. Barcelona, v. VII, nº 146 (046), agosto de 2003.

. A cidade. São Paulo: Contexto, 1997.

. O lugar no/do mundo. São Paulo: Hucitec, 1996.

CARLOS, Ana Fani Alessandri \& OLIVEIRA, Ariovaldo Umbelino. Geografias de São Paulo: representação e crise da metrópole. São Paulo: Contexto, 2004.

.Geografias de São Paulo: a metrópole do século XXI. São Paulo: Contexto, 2004.

CASORLA, Simone Regina \& SILVA, Kleber Wilson Valadares Felizardo da. Atlas da industrialização do estado de São Paulo: poder econômico, trabalho e território (os complexos automotivo e alimentar). Trabalho de Graduação. Instituto de Geociências e 
Ciências Exatas. Universidade Estadual Paulista Júlio de Mesquita Filho. Rio Claro, 2001.

CYMBALISTA, Renato. Estatuto da Cidade. Desenvolvimento urbano, São Paulo, $\mathrm{n}^{\circ}$ 181, 2001. Disponível em: <http://www.polis.org.br/publicacoes>. Acessado em: janeiro de 2006.

D'ARC, Hélène Rivière. Requalificar o século XX: projeto para o Centro de São Paulo. In: BIDOU-ZACHARIASEN, Catherine (coord.) De volta à cidade: dos processos de gentrificação às políticas de "revitalização" dos centros urbanos. São Paulo: Annablume, 2006.

DAMIANI, Amélia; CARLOS, Ana Fani A. \& SEABRA, Odette C. De Lima. O espaço no fim do século: a nova raridade. São Paulo: Contexto, 2001.

DEL RIO, Vicente. Voltando às origens: a revitalização de áreas portuárias nos centros urbanos. Disponível em: <http://www.arquitextos.com.br>. Acessado em: abril de 2007.

DIÁRIO OFICIAL DA UNIÃO. LEI N ${ }^{o}$ 10.257, de 10/07/2001 (Estatuto da Cidade). Seção I (Atos do Poder Legislativo). Edição nº 133 de 11/07/2001.

DIÁRIO OFICIAL. Plano Plurianual Cidade - PPA 2006-2009. Edição no 200, p. 181216. São Paulo, 2005.

DIOGO, Érica Cristina Castilho. Habitação social no contexto da reabilitação urbana da área central de São Paulo. Dissertação (Mestrado em Arquitetura e Urbanismo). Faculdade de Arquitetura e Urbanismo. Universidade São Paulo, São Paulo, 2004.

FIX, Mariana. Parceiros da exclusão: duas histórias da construção de uma nova cidade em São Paulo: Faria Lima e Água Espraiada. São Paulo: Boitempo, 2001.

FOLHA DE SÃO PAULO. Projetos prevêem conciliar comércio e casas. Cotidiano, p. C2, 19/05/2007.

. Novos prédios dão fôlego ao centro velho. Cotidiano, p. C6, 12/05/2007.

. Ações tentam tirar região da ilegalidade. 09/09/2005.

. Prefeitura decide desapropriar Cracolândia. 09/09/2005.

$10 / 03 / 2005$.

"Cracolância" sobrevive à ofensiva policial. Cotidiano, p. C8,

Lançamentos imobiliários na região central crescem $143 \%$ em cinco anos. 20/09/2004a.

$\frac{}{20 / 09 / 2004 \mathrm{~b}}$. . Valorização de imóveis no centro ainda deve levar cinco anos.

. Sem-teto lideram reocupação do centro. Cotidiano, p. C1, 10/04/2002. 
. Volta ao Centro em 450 anos. Especial: Folha Trainee. 04/12/2002.

. Centro de SP perde moradores para a periferia, diz IBGE. 09/05/2001.

FRÚGOLI JR., Heitor. Centralidade em São Paulo: trajetórias, conflitos e negociações na metrópole. São Paulo: Cortez/EDUSP, 2000.

Sobre o alcance do conceito de gentrification para pensar sobre intervenções urbanísticas em áreas centrais de cidades brasileiras: o caso de São Paulo. Anais do Primer Congresso Latinoamericano de Antropología. Rosário, 2005.

FÓRUM CENTRO VIVO. Dossiê-denúncia: violações dos direitos humanos no Centro de São Paulo: propostas e reivindicações para políticas públicas. Disponível em: $<$ http://www.polis.org.br>. Acessado em: abril de 2006.

. Manifesto/escracho. 2005. Disponível em: <http://www.polis.org.br>. Acessado em: outubro de 2005.

O centro da reforma urbana: manifesto por um centro vivo. São Paulo:

Fórum Centro Vivo, 2004a.

. Carta de princípios. São Paulo: Fórum Centro Vivo, 2004b.

HUET, Bernard e outros. Os centros das metrópoles: reflexões e propostas para a cidade democrática do século XXI. São Paulo: Ed. Terceiro Nome/Viva o Centro/Imprensa Oficial do Estado, 2001.

IBGE. Censo Demográfico 1991/2001. Disponível em: <http://www.ibge.gov.br>. Acessado em: abril de 2005.

JEUDY, Henri-Pierre. Espelho das cidades. Rio de Janeiro: Casa da Palavra, 2005.

JORNAL DA TARDE. Masp deve perder a galeria. 18/04/2007.

KARA JOSÉ, Beatriz. A instrumentalização da cultura em intervenções urbanas na área central de São Paulo 1975 a 2000. Dissertação (Mestrado em Arquitetura e Urbanismo). Faculdade de Arquitetura e Urbanismo. Universidade de São Paulo, São Paulo, 2004.

LEFEBVRE, Henri. O direito à cidade. São Paulo: Centauro, 2001. . A revolução urbana. Belo Horizonte: Ed. UFMG, 1999. . La production de l'espace. Paris: Anthopos, 1986.

LIMONAD, Ester \& BARBOSA, Jorge Luiz. Entre o ideal e o real rumo a sociedade urbana - algumas considerações sobre o Estatuto da Cidade. GEOUSP, São Paulo, nº $13,2003$. 
MALERONKA, Camila. Par-Reforma: quem se habilita? - a viabilização de empreendimentos habitacionais em São Paulo através do Programa de Arrendamento Residencial - modalidade reforma: 1999-2003. Dissertação (Mestrado em Habitação). Instituto de Pesquisas Tecnológicas do Estado de São Paulo. Universidade de São Paulo, São Paulo, 2005.

MARICATO, Ermínia. Brasil, cidades: alternativas para a crise urbana. Petrópolis: Vozes, 2001.

. Habitação social em áreas centrais. Mimeo s/ data.

PINTAUDI, Silvana Maria. Espaço e Estado: políticas urbanas em discussão. In: CARLOS, Ana Fani Alessandri \& LEMOS, Amália Inês Geraiges (orgs.). Dilemas urbanos: novas abordagens sobre a cidade. São Paulo: Contexto, 2003.

RIGOL, Sergi Martinez i. A gentrification: conceito e método. In: CARLOS, Ana Fani Alessandri \& CARRERAS, Carles. Urbanização e Mundialização: estudos sobre a metrópole. São Paulo: Contexto, 2005, p. 98-121.

RODRIGUES, Arlete Moysés. Moradia nas cidades brasileiras. São Paulo: Contexto, 1994.

- "Estatuto da Cidade: função social da cidade e da propriedade. Alguns aspectos sobre população urbana e espaço". In: Cadernos da Metrópole, no 12 , São Paulo: EDUC, 2004. p. 9-26.

ROLNIK, Raquel. São Paulo. São Paulo: Publifolha, 2002.

. O Estatuto da Cidade. Folha de São Paulo, São Paulo, 25. jun. 2001.

. A cidade e a lei - legislação, política urbana e territórios na cidade de São Paulo. São Paulo: Studio Nobel/Fapesp, 1997.

. Estatuto da Cidade - instrumento para as cidades que sonham crescer com justiça e beleza, 2001. Disponível em: <http:// www.polis.org.br>. Acessado em: novembro de 2005.

SANTOS, Milton. O espaço do cidadão. São Paulo: Nobel, 1987.

SÃO PAULO (Município). Câmara Municipal de São Paulo. Comissão de Estudos sobre Habitação na Área Central - síntese de relatório final. São Paulo, 2001.

Ação Centro. EMURB. São Paulo, 2004d. 1 CD-ROM.

. EMURB. A cartilha da área central. São Paulo, 1997.

. EMURB. O resgate da área central. São Paulo: Emurb, 1991 a.

. SEHAB. Requalificação Urbana da Nova Luz. São Paulo, 2006a. 
SEHAB. Operação Tripartite CAIXA/CDHU/PMSP: Área Central Nova Luz. São Paulo, 2006b.

. SEHAB. Balanço qualitativo de gestão 2001-2004. São Paulo, 2004a.

. SEHAB. Programa Morar no Centro. São Paulo, 2004c.

. SEHAB. Plano Municipal de Habitação. São Paulo, 2003.

. SEHAB. Programa de Arrendamento Residencial - PAR. São Paulo,

2002b.

. SEHAB. Programa de Requalificação Urbana e Funcional do Centro de São Paulo - PROCENTRO. São Paulo, 1993.

- SEHAB. Projeto Sé-Arouche: Programa Piloto de Ordenação da Paisagem da Área Central. São Paulo, 1992.

- SEHAB. Habitação e Urbanismo: reabilitação do centro. Revista Construção. São Paulo, n 2336, 1992. p. 23-26.

SEHAB. Habitação e Urbanismo: a política que a Prefeitura de São Paulo está praticando. São Paulo, 1991 b.

. SEHAB/PROCENTRO. Morar, viver e trabalhar no centro... Agora é possível. São Paulo, 2002a.

São Paulo, 2001.

PROCENTRO. Reconstruir o Centro: reconstruir a cidade e a cidadania.

.PROCENTRO. Balanço de atividades 1993 - 1998. São Paulo, 1998.

. PROCENTRO. Plano Estratégico 1998-2002. São Paulo, 1998.

1991c.

. SEMPLA. Plano Diretor de São Paulo ao alcance de todos. São Paulo,

- SEMPLA. Planos Regionais Estratégicos: Município de São Paulo: Subprefeitura Sé. São Paulo, 2004b.

. SEMPLA. Plano Diretor e Estratégico do Município de São Paulo. 2003. Disponível em: <http://www.prefeitura.sp.gov/planodiretor $>$. Acessado em: março de 2005.

SASSEN, Saskia. As cidades na economia mundial. São Paulo: Studio Nobel, 1998. 
SCHOR, Silvia Maria. O Estatuto da Cidade e a questão da moradia para as famílias de baixa renda na cidade de São Paulo. Informações FIPE, São Paulo, nº 253, out. 2001, p. 21-24.

SILVA, Helena Menna Barreto. Habitação no Centro de São Paulo: como viabilizar essa idéia? Documento preparado para encontro. Org. LAB-HAB FAU-USP/CEF. São Paulo, 2000.

.O centro de São Paulo: que futuro para a habitação? Mimeo, 2001.

SILVA, José Borzacchiello da. Estatuto da Cidade versus Estatuto de Cidade - eis a questão. In: CARLOS, Ana Fani Alessandri \& LEMOS, Amália Inês Geraiges (orgs.). Dilemas urbanos: novas abordagens sobre a cidade. São Paulo: Contexto, 2003.

SIMÕES Jr. José Geraldo. Revitalização de Centros Urbanos. Pólis, São Paulo, nº 19, 1994.

SMITH, Neil. A gentrificação generalizada: de uma anomalia local à "regeneração" urbana como estratégia urbana global. In: BIDOU-ZACHARIASEN, Catherine (coord.) De volta à cidade: dos processos de gentrificação às políticas de "revitalização" dos centros urbanos. São Paulo: Annablume, 2006.

SOUZA, Denise Lopes de. Intervenciones de rehabilitación y recuperación urbana de áreas degradadas de la ciudad de São Paulo. In: URBAL. Anales del I Encuentro Bienal sobre Rehabilitación Urbana. Lisboa, 1998.

VAINER, Carlos. Pátria, empresa e mercadoria: notas sobre a estratégia discursiva do Planejamento Estratégico Urbano. In: ARANTES, O., VAINER, C. \& MARICATO, E. A cidade do pensamento único: desmanchando consensos. Petrópolis: Vozes, 2000. p.75-103.

VEJA. A solução é derrubar. São Paulo, nº 1938, 11. jan. 2006.

VEJA SÃO PAUlO. Dez idéias para o centro. São Paulo, no 11, p. 12-20, 16. mar. 2005.

VARGAS, Heliana Comin. Centros urbanos: por quê intervir? Seminário Internacional de Reabilitação de Edifícios em Áreas Centrais. São Paulo, 2006.

VIEIRA, Sidney Gonçalves. A definição de centro de São Paulo: o centro da metrópole e a metrópole como centro. Anais do $6^{\circ}$ Simpósio nacional de Geografia Urbana. Presidente Prudente, 1999.

VIEIRA, Vânia Feichas. Os donos do centro: discursos e estratégias de intervenção no centro de São Paulo. Dissertação (Mestrado em Antropologia Social). Departamento de Antropologia Social. Faculdade de Filosofia, Letras e Ciências Humanas. Universidade de São Paulo, São Paulo, 2004.

VILLAÇA, Flávio. Espaço intra-urbano no Brasil. São Paulo: Nobel/Fapesp/Lincoln Institute, 1998. 